\title{
O INVESTIMENTO PÚBLICO E SUA SIGNIFICAÇÃO PARA A ORDEM SOCIAL BRASILEIRA
}

\author{
Dissertação de Mestrado \\ Professor Orientador José Tadeu De Chiara
}

Faculdade de Direito da Universidade de São Paulo São Paulo 2013 


\section{O INVESTIMENTO PÚBLICO E SUA SIGNIFICAÇÃO PARA A ORDEM SOCIAL BRASILEIRA}

Dissertação de mestrado apresentada à banca examinadora da Faculdade de Direito da Universidade de São Paulo, como requisito parcial para obtenção do título de Mestre em Direito sob a orientação do Professor Doutor José Tadeu De Chiara.

UNIVERSIDADE DE SÃO PAULO

Faculdade de Direito

São Paulo

2013 
Banca Examinadora

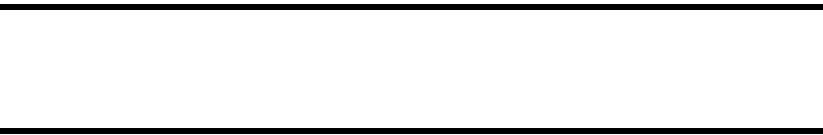




\title{
DEDICATÓRIA
}

Aos meus pais Renato e Noemi e ao meu irmão Rafael, minhas razões de ser.

\begin{abstract}
A Alessandro Baccaglini, "amor, ch'a nullo amato amar perdona, mi prese del costui piacer sì forte, che, come vedi, ancor non m'abbandona"'.
\end{abstract}

${ }^{1}$ ALIGHIERI, Dante. La Divina Commedia. Inferno, Canto V, vv. 103-105. 


\section{AGRADECIMENTOS}

Ao meu orientador, Professor José Tadeu De Chiara, a quem devo tudo o que há de interessante nesta dissertação. 
"O que realmente denuncia a presença do idealismo utópico num sistema constitucional é a disparidade que há entre a grandeza e a impressionante eurritmia da sua estrutura teórica e insignificância do seu rendimento efetivo". Oliveira Vianna 


\section{RESUMO}

YAMAJI, Crisleine Barboza. O investimento público e sua significação para a ordem social brasileira. 2013. 122 f. Dissertação (Mestrado) - Faculdade de Direito, Universidade de São Paulo, São Paulo, 2013.

Esta dissertação, que se baseia em um questionamento teórico, não se pauta na análise de dados numéricos e quantitativos, tão comuns na consideração do investimento público. A escolha vem a desafiar os padrões de análise atualmente adotados para avaliar o investimento público no Brasil. Nesse sentido, busca uma rediscussão da significação do investimento público na ordem social brasileira, a partir de uma análise da semântica do investimento e do público, para verificar sua natureza e seu regime no sistema jurídico brasileiro. A análise do significado leva a concluir que investimento é efeito do agir, mas também da renúncia de agir, renúncia fiscal para incentivar a ação de outro sujeito de direito. Sua natureza de efeito decorrente de um ato jurídico ou uma atividade faz com que seja avaliado em relação à legitimidade, ao objeto e ao próprio processo de tomada de decisão, assim como quanto aos princípios administrativos aplicáveis ao ato que o produz enquanto efeito. Sua natureza de efeito decorrente da renúncia fiscal faz com que seja enquadrado em uma análise de finança pública, de abdicação de receita tributária. A apreciação da função, enquanto exercício do poder a guardar o fim e o resultado, para produção do efeito investimento público, leva à verificação da causa e da sua compatibilidade no que concerne ao objetivo de desenvolvimento. Por fim, seu enquadramento no plano dos efeitos leva à análise final da significação do investimento público quanto à eficácia, efetividade e eficiência para se questionar se o investimento público, considerado segundo padrões econômico-quantitativos, é instrumento efetivo para observância dos preceitos constitucionais.

Palavras-chave: Investimento público. Significação. Função. Estrutura. Ordem social. Desenvolvimento. 


\begin{abstract}
YAMAJI, Crisleine Barboza. The public investment and its meaning to the Brazilian social order. 2013. 122 f. Dissertation (Master of Law) - Law School, University of São Paulo, São Paulo, 2013.
\end{abstract}

This dissertation, based on a theoretical enquiry, is not on a numerical data analysis or a quantitative analysis, commonly considered in relation to the public investment. The choice challenges the standards of analysis currently used to evaluate the public investment, in Brazil. It tries to discuss the meaning of the public investment in the Brazilian social order. It begins through the analysis of the meaning of the concept of investment and public in order to check their nature and their framework in the Brazilian legal system. The analysis of its meaning leads to the conclusion that investment is an effect of the action and an effect of the non action, the fiscal waiver to encourage another agent's investment. The nature of the public investment as an effect produced by an act or an activity takes into account its legitimacy, its purpose and its decision making as well as the administrative principles applicable to the act that produces the effect. The nature of the public investment as an effect produced by a non action, a fiscal waiver, takes into account the investment in the public finance. The function of the public investment as the conduction of the power in consideration to the purposes and the results compels to the analysis of the cause and its adequacy to the development. At the end, as an effect the investment has to be verified as capability, effectiveness and efficiency to challenge if the investment, according to quantitative and economics criteria, is an effective instrument to accomplish the Brazilian constitutional provisions.

Keywords: Public investment. Meaning. Function. Structure. Social Order. Development. 


\section{O INVESTIMENTO PÚBLICO E SUA SIGNIFICAÇÃO PARA A ORDEM SOCIAL BRASILEIRA}

\section{SUMÁRIO}

INTRODUÇÃO .

CAPÍTULO 1. INVESTIMENTO PÚBLICO NO BRASIL: MÚLTIPLAS ANÁLISES DE UM SIGNIFICADO

1.1. Elementos constitutivos do investimento público no Brasil: semântica e natureza. 14

1.2. Elementos estruturais do investimento público no Brasil: aspectos históricos e regime jurídico

CAPÍTULO 2. INVESTIMENTO PÚBLICO NO BRASIL: FUNÇÃO E PLANO DOS EFEITOS

2.1. Função do investimento público no Brasil

2.2. Padrões de análise do investimento público no Brasil: eficácia, eficiência e efetividade. ..98 


\section{INTRODUÇÃO}

Desde pequenos, somos orientados a buscar no dicionário o legítimo significado das palavras. O vernáculo é o produto de um somar de imposições da natureza dos signos. Mas o que é essa semântica sem a sintaxe? Qual é a relação entre os elementos e a função do ser? Na verdade, palavra em si não se basta por seu significado isolado, é pouco sem a observância de suas interações.

O Direito expressa-se pela linguagem e a ela qualifica como jurídica. "A linguagem jurídica é substancialmente uma parte da linguagem corrente". ${ }^{2}$ A consideração do Direito enquanto linguagem tem na natureza sua semântica e na função sua sintaxe. No entanto, o Direito não é somente linguagem que se expõe ou forma que se representa. Não se trata de uma estrutura teórico-conceitual a expressar um novo programa ou a retratar um velho paradigma. Direito é ideia e matéria; conceito e realidade. É fim, função e resultado. O Direito é a linguagem que se faz concreta.

O Direito é "[...] um fenômeno cultural"3 que aprecia os fatos sob o prisma de determinados valores e estabelece seus fins. Consiste em manifestação de natureza axiológica, na medida em que esta pressupõe problemas concernentes à essência do objeto valorado e à projeção histórica daquilo que se valora ${ }^{4}$.

Assim sendo, o jurídico não é somente uma categoria que condiciona uma contemplação das coisas, mas uma modalidade da cultura que dá aos fatos do mundo certa forma e certo tipo ${ }^{5}$. O fato da realidade ao qual o Direito atribui determinado conteúdo é elevado à categoria jurídica, por sua importância no contexto social.

\footnotetext{
${ }^{2}$ OLIVERCRONA, Karl. Linguagem jurídica e realidade. São Paulo: Quartier Latin, 2005, p.17.

${ }^{3}$ RADBRUCH, Gustav. Filosofia do direito. Trad. L. Cabral de Moncada. Coimbra: Armenio Amado, 1997, p. 45.

${ }^{4}$ Cf. REALE, Miguel. Introdução à filosofia. São Paulo: Saraiva, 1989, p.27.

${ }^{5}$ Cf. RADBRUCH, Gustav. Filosofia... op. cit., p. 186.
} 
O homem age no meio social; comporta-se. O direito atribui a esse comportamento, aos fatos, aos atos e às relações humanas um regime; estabelece um conjunto de prescrições normativas a disciplinar as situações e a reger os comportamentos. Cada um desses comportamentos apresenta um conjunto de efeitos que podem ou não ser relevantes em determinada sociedade, sendo apreendidos como elemento da linguagem jurídica.

O investimento público é elemento dessa linguagem, mas sua significação para a ordem social é mais do que a natureza dos seus elementos isoladamente considerados. A semântica do velho dicionário trata o investimento enquanto aplicação de capital para obtenção de lucro, o que poderia levar a uma consideração fática de um ato que se realiza, o qual, apreendido pelo Direito, seria senão ato jurídico. Todavia, o investimento público é mais do que um mero ato; é o efeito do agir ou da renúncia do agir. Por conseguinte, o agir é o ato ou a atividade a conformar o agir público, de sorte que a renúncia de agir é a ausência de ação do ente público, cujo resultado busca produzir um efeito no agir de terceiro.

Enquanto efeito juridicamente considerado, o investimento público é produto da função, do exercício de poder que guarda a causa em sua concretização. Por meio desse efeito, objetiva-se outro efeito central na problemática social brasileira, fim, efeito e direito dessa mesma ordem jurídica: o desenvolvimento.

Os elementos constitutivos serão analisados no que tange ao significado semântico dos elementos e à sua natureza jurídica. Posteriormente, os elementos estruturais levarão em consideração os aspectos históricos e da sua disciplina, na ordem econômicofinanceira. Ainda, será examinado enquanto observância de dever, exercício de poder e cumprimento de função.

O investimento público se expressa por meio do exercício de uma função particular do Estado enquanto agente do interesse público na ordem social. Apresenta suas peculiaridades conforme o momento histórico e os valores e fins constitucionalmente predominantes, mas tem por fim o desenvolvimento. A análise da função liga-se 
diretamente à ideia de causa a fundamentar o efeito planejado. Em acréscimo, complementa-se com uma visão do plano dos efeitos, sendo tratável sob o ponto de vista da eficácia, da efetividade e da eficiência. A eficácia é a predisposição da qual decorre a efetividade e a eficiência. São aspectos da potencialidade e da concretude do efeito investimento público.

A retomada da análise desses conceitos de eficácia, efetividade e eficiência leva à delimitação dos seus aspectos conceituais e ao questionamento sobre o papel da eficiência do Estado, nas finanças públicas, com a averiguação da legitimidade de seu predomínio sob qualquer outro princípio ou sob qualquer direito social a ser concretizado.

Por fim, deve-se salientar que toda a metodologia desta Dissertação tomará como premissa a teoria geral do direito, matizada por uma análise de direito público, a qual organizará um modo de apreensão da realidade na matéria do investimento público como efeito necessário à concretização de objetivos, valores e princípios constitucionais. 


\title{
CAPÍTULO 1. INVESTIMENTO PÚBLICO NO BRASIL: MÚLTIPLAS ANÁLISES DE UM SIGNIFICADO
}

\author{
1.1.Elementos constitutivos do investimento público no Brasil: semântica e natureza. \\ 1.2.Elementos estruturais do investimento público no Brasil: aspectos históricos e regime \\ jurídico.
}

A análise jurídica não poderia começar sem a análise semântica das palavras, visto que a interpretação é a ação que leva ao entendimento ${ }^{6}$. O significado faz-se concreto na medida da interpretação da palavra e é fundamental a atribuição do sentido para bem analisar sua função. Nessa perspectiva, partir-se-á da atribuição do significado aos elementos isolados, seus vocábulos centrais, o investimento e o público; será feita uma análise semântica do substantivo investimento e do adjetivo público para, então, tratar da natureza jurídica da expressão. Também será observada a decisão do investimento enquanto premissa para sua realização.

Apesar de se partir da semântica dos termos investimento e público, não se pretende produzir conceitos de caráter universalista e abstrato, de mera instância lógica; é preferível colher na análise dos fatos sociais os aspectos fundamentais do tratamento da matéria. A significação é concreta e deve ser tomada com base em específicas relações sociais de nossa ordem jurídica. Muitos conceitos podem ser aplicados pelas diferentes ordens jurídicas, mas as soluções apresentadas para determinados problemas sociais (incluindo problemas econômicos) são específicas da ordem social examinada ${ }^{7}$.

O investimento e o público são palavras equívocas de múltiplos significados a se impor no contexto semântico, respectivamente, enquanto substantivo e enquanto qualificativo de quem exerce um poder segundo determinado interesse. Mas não só. Cada palavra a conformar o significado do enunciado investimento público é expressão dos

\footnotetext{
${ }^{6} \mathrm{Cf}$. BETTI, Emilio. Interpretazione della legge e degli atti giuridici - teoria generale e dogmatica. Milão: Giuffrè, 1971, p.10.

${ }^{7}$ Cf. ASCARELLI, Tullio. Studi di Diritto Comparato e in Tema di Interpretazione. Milão: Giuffrè, p. 55 e ss., 1952, p. 3-5, passim.
} 
entendimentos que dão forma ao fenômeno social, o qual se faz jurídico pela importância da consequência dos seus efeitos.

A natureza, nesse sentido, não será observada sem a posterior menção ao funcionamento do instituto. Será fundamental enquanto análise estática do investimento, da sua essência e substância, análise que deverá revelar-se nos requisitos e nos atributos essenciais do investimento público, a determinar a razão de ser do fenômeno jurídico.

O que se concebe por elementos estruturais do investimento público, no Brasil? Este será o tratamento dado após a exposição dos seus elementos constitutivos. Entende-se por estrutura do investimento público a sua disciplina, sua conformação histórica e o próprio regime jurídico do investimento público no Brasil, considerando-se a previsão constitucional da ordem, seu objetivo, seus princípios, seu enquadramento na atividade econômica e em matéria de finanças públicas.

A análise específica do regime jurídico leva à verificação da atribuição constitucional para realização dos investimentos e as formas dessa atribuição - função e dever do Estado e direito e iniciativa dos particulares. Mesmo a verificação do desenvolvimento do país, enquanto objetivo e efeito da ordem, parte de uma análise fundamentada na própria Constituição.

Nesse regime jurídico do investimento público, vislumbra-se um papel que o próprio sistema buscou disciplinar ${ }^{8}$, um ordenamento que deve ser usado como instrumento de transformação social e um meio para atingir os fins e ideais constitucionalmente previstos.

\footnotetext{
${ }^{8}$ Para melhor entendimento do papel do sistema jurídico no direito nacional, fez-se referência a José Reinaldo Lima Lopes, que explica esta preocupação de determinação de um papel mais instrumental ao direito nacional já na primeira metade do século XIX, na escolha entre o papel de um sistema jurídico mais instrumental (instrumento de transformação social) e menos determinista (reflexo das relações sociais existentes). LOPES, José Reinaldo Lima. Iluminismo e Jusnaturalismo no Ideário dos Juristas da Primeira Metade do Século XIX. In JANCSON, Istvan (Org.). Brasil: formação do Estado e da Nação. São Paulo: Hucitec, 2003, p. 202; p.211.
} 


\subsection{Elementos constitutivos do investimento público no Brasil: semântica e natureza}

\section{A Semântica do Investimento}

Investir vem do latim investire, uma palavra de sentido plurívoco e equívoco, que significa atacar, atirar-se com ímpeto, acometer, empossar, tomar posse de (algo), nomear, encarregar-se, empregar recursos, tempo ou esforços em algo ou empregar capitais, uso historicamente recente do vocábulo9 .

O significado do termo investir que aqui nos interessa é aquele que define o investimento como aplicação ou emprego de capitais ${ }^{10}$. O emprego dado à palavra já era observado em cartas de negociantes do século XIV ${ }^{11}$, todavia, a utilização ligada ao capital tornou-se habitual desde o século $\mathrm{XX}$, em decorrência do uso da expressão francesa investir des capitaux ${ }^{12}$. A análise etimológica do termo explica que investir capitais é um anglicismo decorrente do termo invest ${ }^{13}$, cujo sentido é o emprego de capital ou dinheiro na compra de algo de que se espera participação ou lucro ${ }^{14}$.

Capital e dinheiro são duas coisas diversas. "O dinheiro só se torna capital quando usado para adquirir mercadorias ou trabalho com a finalidade de vendê-los novamente com

\footnotetext{
${ }^{9}$ Cf. SILVA, Deonisio da. De onde vêm as palavras: origens e curiosidades da língua portuguesa. Osasco: Novo Século, 2009, p. 573. BUENO, Francisco Silveira. Grande dicionário etimológico-prosódico da língua portuguesa: vocábulos, expressões da língua geral e científica - sinônimos; contribuições do tupiguarani. São Paulo: Saraiva, 1968, p. 1979. FERNANDES, Francisco. Dicionário de sinônimos e antônimos de língua portuguesa. Porto Alegre: Globo, 1980, p. 550. CUNHA, Antônio Geraldo (et. al.). Dicionário etimológico Nova Fronteira da língua portuguesa. Rio de Janeiro: Nova Fronteira, 1999, p. 444. HOUAISS, Antônio; VILLAR, Mauro de Salles. Dicionário Houaiss da língua portuguesa. Rio de Janeiro: Objetiva, 2001, p. 1644.

${ }^{10}$ ALMEIDA, Napoleão Mendes de. Dicionário de questões vernáculas. São Paulo: LCTE, 1994, p. 288; BUENO, Francisco Silveira. Ibidem; FERNANDES, Francisco. Ibidem; CUNHA, Antônio Geraldo (et. al.). Ibidem.

11 CORTELAZZO Manlio; ZOLLI, Paolo. Dizionario etimologico della língua italiana. Bologna: Zanichelli, 1992, p. 620.

12 BATTISTI, Carlo; ALESSIO, Giovanni. Dizionario etimologico italiano. Florença: Barbèra, 1952, p. 2083; DAUZAT, Albert; DUBOIS, Jean; MITTERAND, Henri. Dictionnaire étymologique et historique du français. Paris: Larousse, 1993, p. 399. CUNHA, Antônio Geraldo (et. al.). Ibidem.

13 ALMEIDA, Napoleão Mendes de. Ibidem, p. 288. BUENO, Francisco Silveira. Ibidem. HOUAISS, Antônio; VILLAR, Mauro de Salles. Ibidem.

${ }^{14}$ SIMPSON, J.A.; WEINER, E.S.C. The Oxford English dictionary. Oxford: Clarendon Press, 2004, v. 3, p. 46. GARNER, Bryan A. (Ed.). Black's Law Dictionary. St. Paul, Minn.: Thomson West Group, 2004, p. 844.
} 
lucro" ${ }^{15}$. Assume-se por capital a propriedade privada que concede, mais do que um mero poder sobre coisas, um poder sobre homens ${ }^{16}$, ao passo que o lucro, não necessariamente um resultado numérico quantitativo, é o benefício positivo auferido com base nos fins previamente almejados.

Com efeito, o sentido de investimento apresentado pelo dicionário trata o investimento enquanto ato. Pode ser considerado um conceito pré-jurídico, o que Carnelutti chama de um conceito de domínio, aquele que assume uma relevância jurídica, mas que há uma existência e um valor originário independente do Direito ${ }^{17}$. Essa semântica, porém, não abarca o sentido jurídico do investimento: investimento é consequência, é efeito do emprego do poder de que se dispõe, no caso do particular, ou que se deve empregar, no caso do público, possuindo elementos estruturais que só podem ser compreendidos por meio de uma análise da realidade fática.

Será estudado, quanto à natureza jurídica, o investimento enquanto efeito decorrente do fato jurídico, com foco nesse plano dos efeitos, levando-se em conta o efeito do ato jurídico, na perspectiva do sujeito que o realiza, assim como aquele resultante da renúncia do agir. Não é a própria realidade analisada, mas um esquema da realidade, ou melhor, uma abstração da realidade que considera a mutação de uma situação jurídica (efeito jurídico) e produz ao final outra situação, ou seja, um resultado diverso daquela situação inicial ${ }^{18}$.

\section{A qualificação do público}

A adjetivação do investimento enquanto público é igualmente uma expressão da linguagem jurídica. É uma estrutura de sentido; um produto da interpretação e da práxis social de determinado momento histórico. O Direito, como já ressaltado, é linguagem, mas

\footnotetext{
${ }^{15}$ HUBERMAN, Leo. História da riqueza do homem. Rio de Janeiro: Zahar, 1974, p.167.

${ }^{16}$ Ao tratar da base jurídica do sistema capitalista, Radbruch aponta seus alicerces na liberdade de contratar e na liberdade de propriedade, ou na liberdade contratual, em relação à propriedade a qual impõe mais do que um mero poder sobre coisas e ultrapassa o mero direito patrimonial. RADBRUCH, Gustav. Introdução à Ciência do Direito. São Paulo: Martins Fontes, 1999, p. 79, passim.

17 Cf. CARNELUTTI, Francesco. Teoria generale del diritto. Roma: Soc. Ed. del Foro Italiano, 1951; reestampa: Camerino: Università di Camerino-Edizioni Scientifiche Italiane, 1998, p. 13

${ }^{18}$ Cf. CARNELUTTI, Francesco. op. cit., p. 229.
} 
não se pode pensar que seja somente linguagem, pois é também realidade ontológica, extradiscursiva, na medida em que obriga e coage, quando a ação realizada pelo sujeito não coincide com aquela prevista no conteúdo normativo.

A precisão do significado do investimento público exige a definição do público e traz em mente a tradicional dicotomia: público e privado. Quando se observará um caso de investimento público e não de investimento privado? A delimitação conceitual é fundamental para a construção da espécie fática e para exame do seu regime e de suas consequências. Como ressalta Francesco Carnelutti, “[...] o discurso mediante o qual é construída uma determinada espécie fática é uma definição"19.

Recorreremos a categorias jurídicas tradicionais para bem qualificar em que consiste o investimento público. As modalidades de investimento, assim como a distinção entre o público e o privado, não podem ser consideradas somente uma mera sistematização da matéria, com o fim de facilitar os estudos do jurista; como se verá, são formas de individuação da disciplina aplicável ${ }^{20}$. Bem explica Ascarelli que

[...] as categorias jurídicas importam uma reconstrução tipológica da realidade em função das orientações normativas, porque trazem por sua vez uma avaliação normativa desta realidade. Constituem o instrumento necessário para enquadrar e estabelecer uma realidade que, no concreto dos casos particulares, é continuamente diversa, e desta forma permite a comparação entre os vários casos e seu julgamento ${ }^{21}$.

A diferenciação entre o público e o privado é uma dicotomia tradicional, uma das grandes dicotomias existentes no estudo do Direito. Parte da consideração de Ulpiano de que "[...] o direito público diz respeito ao estado da coisa romana, enquanto o privado diz respeito à utilidade dos particulares" 22 .

\footnotetext{
${ }^{19}$ CARNELUTTI, Francesco. op. cit., p. 234.

${ }^{20}$ Cf. ASCARELLI, Tullio. Studi... op. cit., passim.

${ }^{21}$ ASCARELLI, Tullio. Studi... op. cit., p. 13.

22 "Huius studii duae sunt positiones, publicum et privatum. Publicum jus est quod ad statum rei romanae spectat, privatum, quod ad singulorum utilitatem". ULPIANO. Digesto, 1.1.1.2.
} 
A dicotomia ajuda a organizar coerentemente a matéria, permitindo a sistematização do seu conteúdo e a determinação do seu âmbito de análise ${ }^{23}$, originando-se de uma análise estática do próprio sistema jurídico, para influenciar a própria interação dinâmica de seus elementos. A separação é feita por uma fronteira cada vez menos rígida e se pode verificar uma mútua influência de uma parte em relação à outra. De qualquer modo, não se concorda com aqueles que entendem que a divisão tem pouca utilidade e operacionalidade ou que foram derrubadas as suas fronteiras ${ }^{24}$.

Defendendo-se sua relevância na definição conceitual, passa-se então a ponderá-la sob alguns prismas de análise, segundo uma possível diferenciação entre o público e o privado, de acordo com as esferas, os sujeitos, os bens e os direitos.

Como se pode observar, busca-se lutar com a inexatidão da linguagem, com o objetivo de precisar conceitualmente a matéria discutida. E mais uma vez se afronta um conceito equívoco, a esfera, que pode significar uma superfície, um domínio no qual se exerce uma ação, uma atividade ou um conjunto de interesses. Apreendida juridicamente, como ressalta Natalino Irti, a imagem geométrica da esfera é usada porque expressa a ideia de confim e de limite, revelando aquilo que está dentro e aquilo que está fora ${ }^{25}$.

Tendo em vista a distinção entre o público e o privado, enfatiza Tércio Sampaio Ferraz Jr: “[...] quando Ulpiano distinguia o jus publicum e o jus privatum certamente tinha em mente a distinção entre a esfera do público, enquanto lugar da ação, do encontro dos homens livres que se governam, e a esfera do privado, enquanto lugar do labor, da casa, das atividades voltadas à sobrevivência" 26 . Explica o autor, no entanto, que o conceito perde sua nitidez já na Idade Média e, na Idade Moderna, é redefinido com base na

${ }^{23}$ Cf. BOBBIO, Norberto. Dalla struttura alla funzione: nuovi studi di teoria del diritto. Roma-Bari: Laterza, 2007, p. 123.

${ }^{24}$ Vide, por exemplo: FRANKENBERG, Günter. Constructing legal traditions introductory remarks on the public/private-distinction as tradition. Comparative Law Review, v.2, n.1, p. 1-12, 2011;

FRANKENBERG, Günter. Shifting Boundaries: The Private, the Public, and the Welfare State. In: KATZ, Michael B.; SACH $\beta E$, Christoph (Coord.). The Mixed Economy of Social Welfare. Baden-Baden: Nomos, p. 72-94, 1996.

${ }^{25}$ Cf. exposição de Natalino Irti, na série de conferências sobre o direito na idade da técnica. IRTI, Natalino. Verso un superamento del diritto? - Il destino del diritto e la volontà di potenza della tecnica. In: Fondazione Italiana per Il Notariato; Fondazione Corriere della Sera. Il diritto nell'età della tecnica. 17 mai. 2012.

${ }^{26}$ FERRAZ Jr., Tercio Sampaio. Introdução ao Estudo do Direito. São Paulo, Atlas, 2007, p.134. 
distinção entre o social e o individual, preponderando sobre a ideia de domínio da ação política, a qual passa a ser tida como produtora de bens ${ }^{27}$.

A esfera do privado, a qual passa a ser delimitada pelos valores burgueses da liberdade, da igualdade formal e da propriedade, garante-se pela disponibilidade do interesse e pelo exercício do direito subjetivo. Por seu turno, a esfera do público passa a ser caracterizada pela atuação do Estado, primeiro, um Estado gendarme, de garantia de segurança, justiça e ordem; depois, um Estado dirigente, de intervenção na esfera privada ou no domínio econômico ${ }^{28}$.

O delineamento das esferas pública e privada faz com que se pense na ideia de interesse, que foi considerado por tantos autores preponderante na sua definição ${ }^{29}$. Poderse-ia obviamente adentrar nas discussões travadas pelos juristas do século XIX, quanto à importância do interesse na definição do direito público ou do direito privado, porém, cada autor põe em foco um elemento de análise, seja o fim, seja o interesse, seja a propriedade. O que não se pode ignorar, sem dúvida, é a relevância do interesse na composição do próprio direito.

Esta análise parte do conteúdo da relação jurídica que há de apontar um interesse prevalente, interesse público ou social para as relações de direito público e interesse particular ou privado para as relações de direito privado ${ }^{30}$. Neste caso, por exemplo, o adjetivo expressa o próprio objetivo a que corresponde o interesse e o seu objeto de destinação ${ }^{31}$.

\footnotetext{
${ }^{27}$ FERRAZ Jr., Tercio Sampaio. Introdução... op. cit., p.134-135, passim.

${ }^{28}$ Preferiu-se não entrar em detalhes, neste trabalho, o conceito e as teorias sobre as esferas públicas e privadas no âmbito das teorias sociais. Não se ignora, no entanto, a importância do aprofundamento nos estudos de Habermas, Nancy Fraser, Benhabib e Howhendahl, entre outros.

${ }^{29}$ Dentro da própria Faculdade de Direito da Universidade de São Paulo, por exemplo, docentes como o Professor Emérito Reinaldo Porchat, apoiado por Dernburg, defendia que a clássica divisão romana se fundamentava no interesse preponderante, seja este do Estado, seja dos particulares. Cf. TELLES Jr., Goffredo da Silva. Introdução à Ciência do Direito. Faculdade de Direito da Universidade de São Paulo. Departamento de Apostila do Centro Acadêmico XI de Agosto, São Paulo, 1953, p.197.

${ }^{30}$ Cf. REALE, Miguel. Lições preliminares de direito. São Paulo: Saraiva, 2000, p. 342.

${ }^{31}$ COMPARATO, Fabio Konder. Função social da propriedade dos bens de produção. Revista de Direito mercantil, n. 63, p. 71-79, jul./set. 1986., p. 75.
} 
Conforme explica Paul Roubier, “[...] à diferença do direito privado, um complexo de direitos e obrigações, o direito público é um complexo de poderes e deveres, e se vincula em função dos poderes e deveres, considerando-se como legítimos somente na medida em que sirvam ao interesse geral $^{32}$.

A própria ideia de justiça comutativa e distributiva, de acordo com Radbruch, funda aquela distinção no substrato do Direito. A primeira está fundamentada nas relações particulares, características do direito privado, em que há coordenação e igualdade entre os elementos considerados, ainda que sopesadas pela limitação do poder e pela consideração da vulnerabilidade de um indivíduo em relação ao outro. A justiça distributiva, de outra forma, pressupõe relações de bem comum, características do direito público, em que há subordinação ou desigualdade entre os elementos considerados ${ }^{33}$.

Assim como as situações fáticas, nem todos os interesses são apreendidos pelo direito e por ele qualificados. Há de se levar em conta o interesse juridicamente protegido ou tutelado, em linha do que defende Jhering, tanto que se define na teoria geral do direito o próprio direito subjetivo do autor e, no direito processual, o próprio interesse de agir em juízo: de fato, é condição da ação, segundo o artigo $3^{\circ}$ do Código de Processo Civil. Qualificado como público, o interesse passa a ter ainda uma proteção adicional de duas instituições após a Constituição de 1988, o Ministério Público e a Defensoria Pública.

Na esfera pública, portanto, prevalece o interesse público, enquanto na esfera privada, o interesse particular. Mas aqui surge uma nova discussão: público pode ser restrito ao que diz respeito ao interesse da Administração Pública ou engloba também o interesse coletivo? Parece um questionamento sem sentido, mas pode ter importantes repercussões práticas. Jhering já buscava esclarecer uma diferenciação entre o privado, o público e o coletivo, partindo da ideia de diferentes tipos de propriedade e seus titulares ${ }^{34}$. A ideia é retomada por Ugo Mattei, na discussão sobre a privatização dos bens públicos na Itália, como se mencionará a seguir, na classificação dos bens públicos.

\footnotetext{
${ }^{32}$ ROUBIER, Paul. Droits subjectifs et situations juridiques. Paris: Dalloz, 2005, p. 113.

${ }^{33}$ Cf. RADBRUCH, Gustav. Introdução... op.cit., p. 253.

${ }^{34}$ Cf. TELLES Jr., Goffredo da Silva. Introdução...op. cit., p.198.
} 
A aplicação da dicotomia pode ser feita em relação à qualificação dos bens. $\mathrm{O}$ reconhecimento do qualificativo possui efeitos relevantes, na análise do público. De acordo com o capítulo III do Código Civil vigente, artigo 98, "são públicos os bens do domínio nacional pertencentes às pessoas jurídicas de direito público interno; todos os outros são particulares, seja qual for a pessoa a que pertencerem”. Para Caio Mario da Silva Pereira, a classificação "[...] assentou-se no critério subjetivo da titularidade, e, ao adotá-lo, teve em vista a simplicidade doutrinária e a necessidade de um sistema prático de disciplina" ${ }^{35}$. O critério teórico de classificação adotado pelo Código pode trazer certa confusão e, apesar dos termos, faz-se necessário interpretar o artigo em linha do Código anterior, tomando como bens de domínio nacional não somente aqueles federais, mas inclusive os estaduais e municipais.

O mesmo Código Civil apresenta uma classificação dos bens públicos segundo o modo como são utilizados ou sua destinação principal. Assim, no artigo 99, são bens públicos aqueles de uso comum do povo (rios, mares, estradas, ruas e praças); há os bens de uso especial (edifícios ou terrenos destinados a serviço ou estabelecimento da administração federal, estadual, territorial ou municipal, inclusive os de suas autarquias); e os bens dominicais (o patrimônio das pessoas jurídicas de direito público, como objeto de direito pessoal, ou real, de cada uma dessas entidades, ou mesmo os bens pertencentes às pessoas jurídicas de direito público, a que se tenha dada estrutura de direito privado).

Essa classificação comporta muita discussão quanto aos critérios que devem ser adotados para o enquadramento dos bens públicos, mas é fundamental para a análise prática. O Código não apresenta critérios claros para o enquadramento dos bens, contudo, deixa claro que determinadas categorias são inalienáveis (bens de uso comum do povo e de uso especial). A inalienabilidade é a decorrência da afetação ou da destinação dos bens, mas pode ser alterada caso haja uma mudança expressa ou tácita de sua categoria.

\footnotetext{
${ }^{35}$ PEREIRA, Caio Mario da Silva. Instituições de Direito Civil. Rio de Janeiro: Forense, 2009, v.1, p.376.
} 
Nota-se que o legislador faz uma escolha de inclusão dos bens coletivos dentro da categoria bens públicos. Parece irrelevante chamar atenção para esse fato, porém, como já mencionado, a diferenciação doutrinária é antiga e volta a fazer parte da pauta de discussões. A confusão entre o coletivo e o público, ou melhor, a apropriação do bem coletivo pelo sujeito público (entenda-se público aquele de titularidade da Administração Pública) é posta em discussão pelos doutrinadores, no movimento de privatizações.

A natureza dos bens públicos de uso comum e de uso especial não permite o uso exclusivo da coisa. Sua inalienabilidade seria absoluta, como de tantos outros bens de domínio público. No entanto, parece que a conveniência do governo encarregado pela Administração Pública tem possibilitado sua desafetação para domínio privado, seja no exercício e na prestação do serviço, seja na titularidade do ativo. Encontram-se rapidamente os requisitos de interesse público, leia-se interesse governamental, para fundamentar a alienação dos bens.

Na Itália, por exemplo, as privatizações dos bens comuns pelo Estado às empresas transnacionais levaram a duras críticas do doutrinador civilista Ugo Mattei, que passou a questionar, por meio do seu "Manifesto dos Bens Comuns", a legitimidade do Estado em se apropriar, negociar e transferir os bens coletivos ao domínio privado. É oportuna uma breve citação da defesa introdutória de Ugo Mattei, no seu Manifesto, pela concordância com suas palavras e necessária reflexão sobre elas em um país (o nosso) onde a apropriação privada do bem público e do bem coletivo parece ser aceita como consequência natural da modernização e do "desenvolvimento":

[...] Em um processo de privatização o governo não vende aquilo que é seu, mas aquilo que pertence pro quota a cada um dos componentes da comunidade, assim como, quando expropria um campo para construir uma autoestrada, esse adquire coativamente uma propriedade que não é sua. Isso significa que cada processo de privatização decidido pela autoridade política por meio do governo pro tempore expropria cada cidadão (e não somente os cidadãos) da sua quota-parte do bem comum expropriado, assim como ocorre no caso da expropriação de um bem privado. Todavia, enquanto a tradição constitucional liberal tutela $o$ proprietário privado no confronto da autoridade pública (Estado) por meio do instituto da indenização pela expropriação (ou mesmo pela chamada reserva de lei), nenhuma tutela jurídica (muito menos 
constitucional) existe nos confrontos do Estado que transfere ao privado bens da coletividade (bens comuns) que não sejam detidos em propriedade privada. ${ }^{36}$

Retomando-se os diferentes aspectos da dicotomia, a diferença entre o público e o privado pode ser vista também, conforme sugere Norberto Bobbio, no emprego historiográfico dos seus termos, nos quais o direito público e o privado não são somente duas partes contrapostas em um sistema, mas fases da evolução do próprio direito, ora com uma tendência predominantemente privatista, ora com uma tendência predominantemente publicística, tal como observado na passagem de um modelo liberal para um modelo social do Estado ${ }^{37}$.

Ademais, predomínio da tendência publicística do Estado não é senão decorrência de fatos históricos que marcam a crise de um modelo liberal proposto, com a necessidade de superação de uma postura de um Estado gendarme, garantidor da ordem, da segurança e da paz $^{38}$. Com a ampliação de suas funções, o Estado assume a qualidade de promotor do bem-estar e passa "[...] a dar guarida aos reclamos identificados nas tensões sociais ressaltadas nas crises que caracterizaram o funcionamento das economias de modelo liberal no século XIX"39.

O uso historiográfico poderia ser considerado também, sob outro ponto de vista, quanto à forma da divisão. Ainda que o direito público seja ligado às relações coletivas e o direito privado às relações individuais, a distinção assume formas muito diversas em cada período histórico.

Esse uso historiográfico leva igualmente a uma análise axiológica da dicotomia, por meio da qual há de se ressaltar as valorações quanto ao retrocesso e ao progresso histórico no predomínio de uma tendência publicística ou privatista, em cada período ${ }^{40}$. Em outras

\footnotetext{
${ }^{36}$ MATTEI, Ugo. Beni Comuni - un manifesto, Roma-Bari: Laterza, 2011, p. V-VI.

${ }^{37}$ Cf. BOBBIO, Norberto. op. cit., p. 128-129, passim.

38 VIDIGAL, Geraldo de Camargo. Fundamentos do Direito Financeiro. São Paulo: Revista dos Tribunais, 1973 , p. 143-144.

${ }^{39}$ DE CHIARA, José Tadeu. Moeda e ordem jurídica. 1986. Tese (Doutorado) - Faculdade de Direito, Universidade de São Paulo, São Paulo, 1986.

${ }^{40}$ Cf. BOBBIO, Norberto. op. cit., p. 130-131, passim.
} 
palavras, em um exame dos defensores de predominância de valores privados, é um retrocesso a passagem de um Estado Liberal para um Estado com atuação na atividade econômica, assim como para aqueles de tendência publicística se configuraria um retrocesso a passagem de um Estado de Bem-Estar Social aos padrões neoliberais. A passagem do Estado liberal ao Estado social leva à reformulação de um modelo de Estado e do predomínio de novos valores, o que Paulo Bonavides chama de uma "efetiva transformação superestrutural" ${ }^{41}$.

A distinção entre o público e o privado expõe ainda a diferença quanto ao status do sujeito de direito e a disponibilidade dos interesses por esse sujeito. O sujeito de direito é aquele que tem um "[...] poder de ação contido na norma" 42 . A norma, com efeito, prevê uma regra de conduta seja ao sujeito público, seja ao sujeito privado da qual, em qualquer caso, decorre a observância da função a qual se destina. Entretanto, para aquele há o dever de observá-la nos limites da conduta prescrita; para este há o direito subjetivo de fazê-la observar nos limites do seu interesse juridicamente protegido.

Os deveres jurídicos incluem os deveres morais, os deveres legais e os deveres sociais. Não são todos os deveres morais qualificados como deveres jurídicos, mas somente aqueles considerados relevantes para a ordem social em análise. Os deveres legais são os deveres resultantes de disposições formais de leis e regulamentos, enquanto os sociais são aqueles que encontram sua fonte dentro dos usos e costumes ${ }^{43}$. Os deveres do sujeito de direito público são deveres legais e devem ser observados nos limites a ele prescritos, sendo aplicados na medida em que não contrariem os princípios e as garantias fundamentais constitucionalmente previstos.

Os deveres são a expressão de um poder com justificativas constitucionais e legais determinadas, as quais devem ser seguidas para que a ordem estruture um efetivo equilíbrio social ${ }^{44}$. De outra forma, os direitos subjetivos são definidos quer como interesse

\footnotetext{
${ }^{41}$ BONAVIDES, Paulo. Do estado liberal ao estado social. Rio de Janeiro: FGV, 1972, p. 205.

42 PEREIRA, Caio Mário da Silva. op.cit., p. 10.

${ }^{43}$ Cf. ROUBIER, Paul.op.cit., p. 100, passim.

${ }^{44}$ A ideia de direito como meio de equilíbrio social é inspirada na lição de Goffredo da Silva Telles Jr. Cf. TELLES Jr., Goffredo da Silva. Introdução... op.cit., p. 157, passim.
} 
juridicamente protegido, conforme a clássica definição de Jhering, quer como o poder da vontade de seu titular, segundo a clássica definição de Savigny ${ }^{45}$.

Assim, percebe-se que o particular, titular de um direito subjetivo, ao exercer seu direito, pode dele dispor, a ele renunciar ou simplesmente transmiti-lo. Tem a iniciativa em termos constitucionais, pois toma uma decisão em face de uma situação jurídica subjetiva, caracterizada pela disponibilidade do direito ou pela disponibilidade da coisa.

O Estado não é titular de um direito subjetivo, mas de um dever, como bem ressalta José Tadeu De Chiara ${ }^{46}$. Maneja poderes para a satisfação de determinadas finalidades que não condizem com interesse próprio, mas com o interesse de outrem ${ }^{47}$. Exerce uma função estritamente delimitada por uma previsão constitucional e legal, para atendimento do interesse público, e não tem disponibilidade dos seus interesses. Não pode renunciar ou transmitir esse dever sem expressa permissão legal.

Por conseguinte, a dicotomia entre o investimento público e o investimento privado pode se pautar nas características distintivas do público e do privado no Direito, conforme expostas acima. Obviamente, o investimento é fato da realidade que prescinde de uma conceituação jurídica para sua caracterização. Todavia, na medida em que apreendido pelo Direito, o investimento pode ser diferenciado até mesmo de acordo com características de uma dicotomia jurídica tradicional e, a partir daí, ser observado de uma estrutura abstrata a um efeito real.

\section{A natureza jurídica do investimento público}

Verificada a semântica do substantivo investimento e do qualificativo público, poder-se-ia pensar que investimento público é a soma desses significados. Assim, a escolha de um critério metodológico baseado na teoria geral do direito levaria então a considerar o

${ }^{45}$ Cf. ROUBIER, Paul. op. cit., p.67.

${ }^{46}$ Cf. DE CHIARA, José Tadeu. Aulas ministradas no curso de Direito Econômico II e Direito Econômico aplicado na Faculdade de Direito da Universidade de São Paulo nos anos de 2007, 2009, 2010 e 2011. São Paulo, 2011.

${ }^{47}$ Cf. MELLO, Celso Antônio Bandeira de. Curso de Direito Administrativo. São Paulo: Malheiros, 2009, p. 71-72. 
investimento enquanto ato jurídico matizado pelo regime de direito público. Mas esta é uma simplificação que desconsidera a realidade do investimento. O investimento público não é somente um agir, um ato jurídico público: é o efeito do agir e também o efeito da renúncia desse agir.

Parece que se acaba de expor uma contradição; no entanto, a aplicação de capital com o objetivo de lucro é a decorrência de um ato administrativo ou de uma atividade estatal de intervenção, que pode se expressar também em uma medida de renúncia, a renúncia fiscal, a qual leva a um direcionamento do investimento de sujeitos diversos da Administração Pública. Tomado enquanto espécie englobada nas finanças públicas, o investimento público caracteriza-se pelo efeito a se considerar, na definição das peças orçamentárias.

Fica clara, portanto, a consideração do investimento enquanto efeito de um agir e de uma abstenção de agir. O investimento público é o elemento a tecer uma realidade de atuação estatal, um efeito da própria política estrutural do Estado, a buscar concretizar outro efeito, o desenvolvimento. Por sua vez, o investimento público não pode se restringir a um mero elemento da regulação de conjuntura, chamada, pelos franceses, de política dos "Quatro E": équilibre du buget, éparge, exportation, emploi ${ }^{48}$ (equilíbrio orçamentário, poupança, exportação e emprego), mas um elemento de regulação estrutural.

O investimento é um efeito do emprego do poder, a produzir uma interferência legítima na esfera de interesses alheia. Explica-se. Se o instrumento monetário é expressão de um sistema de direito que dá ao seu titular o poder de exercer direitos e de se exonerar de deveres de conteúdo patrimonial, na abordagem de José Tadeu De Chiara ${ }^{49}$, o investimento não é senão o resultado do exercício desse poder, no processo de produção de bens e serviços. Traz um incremento no processo produtivo, por meio do ato administrativo ou da renúncia de parcela da arrecadação tributária.

${ }^{48}$ FOURNERET, Pierre. Que sais-je? L'Administration Économique. Paris: Presses Universitaires de France, 1980, p.51.

${ }^{49}$ Cf. DE CHIARA, José Tadeu. Aulas... op.cit. 
O foco no sujeito e na sua decisão leva a considerações da própria qualificação do investimento no sujeito que emprega o poder. Já se mencionou, neste trabalho, a diferenciação do público e do privado quanto ao status do sujeito. Contudo, não é possível considerar como investimento público todo aquele realizado por um sujeito de direito público, e o investimento privado todo aquele concretizado por um sujeito de direito privado. O sujeito de direito público pode realizar um investimento privado, ou seja, um investimento sujeito a princípios e regras de liberdade de iniciativa e concorrência, em igualdade de posição aos investidores privados. Da mesma forma, o sujeito de direito privado pode realizar um investimento conforme limitações e finalidades do interesse público.

Em vista da insuficiência dessa distinção, pautada exclusivamente na qualificação do sujeito titular do investimento, é preciso ter em vista outros modos de diferenciação apontados na dicotomia tradicional entre o público e o privado.

O investimento privado caracteriza-se pelos efeitos de uma relação jurídica de coordenação e de igualdade entre os sujeitos, sendo interesses particulares os interesses prevalecentes. O sujeito do investimento privado exerce seu direito subjetivo patrimonial levando em consideração vetores de segurança, rentabilidade e liquidez, vetores qualificadores de uma disponibilidade dos interesses pelo sujeito de direito. A segurança caracteriza-se pelo nível de exposição a risco a que o sujeito de direito está disposto a se submeter, a fim de atingir certa rentabilidade; esta se dá pela vantagem obtida por meio do exercício do direito, enquanto a liquidez se efetiva pela possibilidade e disponibilidade do exercício de direitos subjetivos. Todos esses vetores são efeitos do exercício de direitos subjetivos patrimoniais ${ }^{50}$.

O investimento público, ao revés, pressupõe uma relação jurídica de desigualdade entre as partes, com subordinação e autoridade de um em relação ao outro, sendo justificada pela prevalência do interesse geral ou interesse público que permeia a relação estabelecida. Não há escolha pautada em disponibilidade de interesse, porque o sujeito

\footnotetext{
${ }^{50}$ Cf. DE CHIARA, José Tadeu. Aulas... op.cit.
} 
titular do investimento público exerce seu dever, levando em conta funções constitucionalmente previstas, utilizando poderes para o atendimento das finalidades propostas para o ente público considerado. Dessa forma, não fundamenta sua decisão exclusivamente em vetores de segurança, rentabilidade e liquidez, mas de manejo de custos e benefícios sociais.

Em acréscimo, o tratamento do investimento público enquanto efeito do ato jurídico de investimento público se orienta pelos princípios de direito administrativo que o permeiam, os seus pressupostos essenciais enquanto ato jurídico e a sua finalidade. A verificação dos pressupostos conduz ainda à análise de elementos ligados à decisão do investimento público e do sujeito a realizá-lo.

A análise genérica do sujeito a realizar o investimento público será feita a partir dos pressupostos essenciais do sujeito, ou seja, a capacidade, a legitimação e a idoneidade do objeto analisado. Esses são elementos essenciais a qualquer sujeito de atos jurídicos e não desconsideram as peculiaridades dos atos jurídicos públicos que serão tratados a seguir. Não se vê nesse tratamento uma tentativa de amoldar uma teoria pública à teoria privada dos atos jurídicos. Pode ser vislumbrada, em linha da teoria desenvolvida por Vicente Ráo, uma teoria geral aplicável aos atos jurídicos com alguns elementos peculiares a todos os atos jurídicos de direito público.

A argumentação exposta não se deterá à análise da investidura dos agentes em atos específicos, porém, tratará da aptidão genérica do sujeito de direito público traduzida para o sentido de competência ou, ainda, sua capacidade objetiva, um pressuposto que se liga à própria função e não à pessoa que a exerce ${ }^{51}$. A função específica do sujeito a realizar o investimento público é restrita aos termos legais e à própria função do investimento na ordem jurídica social.

${ }^{51}$ Em conformidade à doutrina de Vicente Ráo, que segue Duguit em suas explicações. RÁO, Vicente. Ato Jurídico - noção, pressupostos, elementos essenciais e acidentais. O problema do conflito entre os elementos volitivos e a declaração, atual. Ovídio Rocha Barros Sandoval. São Paulo: Revista dos Tribunais, 1999, p.108. 
A legitimação no investimento público poderia ser discutida na medida em que se constitua um requisito a mais na análise da competência. Não se restringe à legitimidade de agir do sujeito, de maneira que expressa a limitação do poder, os limites da previsão normativa e a justificativa para o exercício do dever. Daí decorre na sociologia, especialmente na doutrina de Max Weber, a análise do poder legítimo e da fundamentação da autoridade e da dominação ${ }^{52}$. A dominação, ou imposição de comportamentos pela autoridade no exercício do seu poder em relação a terceiros, não pode ultrapassar esses limites impostos por lei.

Todavia, a noção de legitimação e legitimidade pode ser estudada sob diversos pontos de vista. Segundo Paul Roubier, a legitimidade pode ser examinada do ponto de vista moral, político e estritamente jurídico. A legitimidade moral parte de uma análise idealista, de um enfoque do bem e do mal, do justo e do injusto, na condução da sociedade humana. Por sua vez, a legitimidade política diz respeito a uma análise realista, ao modo de exercício do poder para a garantia do bem-estar do grupo social a que se representa. Por fim, a legitimidade jurídica trata de uma análise formal, da regularidade da situação jurídica e da compatibilidade do comando ao previsto na regra abstrata ${ }^{53}$

A idoneidade do objeto é, conforme expressão de Francesco Carnelutti, "[...] o modo de ser jurídico" ${ }^{54}$ e concerne à sua aptidão em produzir efeitos. Verifica-se a idoneidade nos próprios elementos de validade do objeto, isto é, na sua licitude, sua possibilidade e sua determinação. O objeto lícito é aquele conforme o ordenamento jurídico; o possível é o objeto realizável; o determinado ou determinável é aquele que se pode $\operatorname{precisar}^{55}$.

Entrementes, seguir a linha de Vicente Ráo, quanto aos elementos gerais e elementos peculiares dos atos jurídicos de direito público, não significa concordar absolutamente com todos os elementos por ele apresentados, já que o autor restringe e

\footnotetext{
${ }^{52}$ Vide WEBER, Max. Economia e sociedade. Brasília: Ed. UnB, v.1 e v.2, 2000.

${ }^{53}$ Cf. ROUBIER, PAUL.op.cit., passim.

${ }^{54}$ CARNELUTTI, Francesco. op. cit., p. 240.

${ }^{55}$ Cf. PEREIRA, Caio Mario da Silva. op.cit., p.416-417, passim.
} 
identifica o ato jurídico de direito público à Administração Pública. Dentre os elementos discutidos pelo autor, encontram-se a distribuição legal e constitucional da competência, os sujeitos aos quais essa competência é distribuída, os princípios aos quais são submetidos e seu caráter de tipicidade ${ }^{56}$

Vale, mais uma vez, a ressalva de que não se considera o ato jurídico público somente aquele cuja competência é restrita aos diferentes poderes e órgãos da Administração Pública, primeira característica comum aos atos jurídicos públicos apontada por Vicente Ráo ${ }^{57}$. Segundo já se explicitou neste texto, entende-se que o sujeito de direito, por si só, não determina a natureza do ato jurídico e pode o sujeito público realizar atos jurídicos de regime privado.

Com efeito, os atos jurídicos públicos são delineados por preceitos limitativos estabelecidos em normas jurídicas que atribuem poderes-funções ao sujeito que o exerce. São normas imperativas, as quais possuem motivos determinantes específicos a caracterizar o exercício do poder na realização dos atos jurídicos, dotados geralmente de tipicidade ${ }^{58}$.

O tratamento do investimento público enquanto ato jurídico público leva a tecermos breves considerações a respeito do ato jurídico administrativo. E, na análise do ato administrativo, enquanto espécie do ato jurídico público, a recordar os princípios previstos na Constituição para o seu exercício.

Conforme previsão do artigo 37, a Administração Pública direta e indireta de qualquer dos Poderes da União, dos Estados, do Distrito Federal e dos Municípios obedecerá aos princípios de legalidade, impessoalidade, moralidade, publicidade e eficiência. Explica José Afonso da Silva que os princípios constitucionais da Administração Pública são “[...] destinados, de um lado, a orientar a ação do administrador na prática dos atos administrativos e, de outro lado, a garantir a boa administração, que se

\footnotetext{
${ }^{56}$ Cf. RÁO, Vicente. op. cit., p. 76.

${ }^{57}$ Ibidem.

${ }^{58}$ Ibidem.
} 
consubstancia na correta gestão dos negócios públicos (dinheiro, bens e serviços) no interesse coletivo" 59 .

A legalidade inclui não somente a atribuição de poderes e funções à Administração Pública, mas também a previsão dos fins para o seu exercício. Segundo Celso Antonio Bandeira de Mello, é a legalidade o princípio que qualifica e dá a identidade particular do Estado de Direito ${ }^{60}$. Caracteriza-se como um dos princípios basilares do regime jurídico da Administração Pública e um direito e garantia fundamental, nos termos do artigo $5^{\circ}$, II da Constituição; traz intrínseco o fundamento da sua atuação, qual seja, aquele para o qual a Administração está restrita a atuar naquilo que lhe é permitido em lei (leia-se normas constitucionais e infraconstitucionais), e o particular só é obrigado nos termos dessa mesma lei. Essa é uma diferença evidente na atuação dos particulares, porque estes não estão adstritos ao expressamente permitido na sua autonomia.

De seu lado, o princípio da impessoalidade é aplicável não somente na relação da Administração com os administrados, mas também é reflexo da finalidade pública de isonomia de tratamento dos administrados. Aplica-se ainda à própria Administração Pública, sendo o ato uma expressão do exercício da função e não da pessoa que o pratica.

Ao se fixar a isonomia de todos os sujeitos privados perante a Administração, não significa que o ato administrativo não possa ser direcionado a um grupo determinado em detrimento de outro, conforme finalidade expressamente prevista em lei. Não obstante, dentro desse grupo para o qual o ato administrativo é direcionado, não pode haver um tratamento pessoal e não isonômico entre seus elementos. Importa ressaltar esse princípio em relação ao investimento público, visto que, nas atividades de intervenção do Estado na ordem econômica, pode ser oferecido um tratamento diferenciado a um grupo em detrimento a outro, por exemplo, a provocar efeitos de investimento e incentivos ao setor pesqueiro ou agropecuário ou a certos ramos da indústria nacional.

${ }^{59}$ SILVA, José Afonso da. Curso de Direito Constitucional Positivo, São Paulo: Malheiros, 2008, p. 666.

${ }^{60}$ Cf. MELLO, Celso Antônio Bandeira de. op.cit., p. 100. 
Quanto ao princípio da publicidade, este também é importante na análise do investimento público enquanto ato administrativo. Traz consigo a transparência e a divulgação das informações como obrigação inerente e como critério preponderante, cuja relativização deve ser expressamente autorizada por lei ou pela Constituição a séquito dos imperativos de segurança nacional ou de interesse público na realização de um investimento estratégico. Esta é uma consequência do próprio funcionamento do Estado Democrático de Direito, por esta razão, igualmente vinculado aos direitos e garantias fundamentais tratados no artigo $5^{\circ}$, XXXIII e XIV da Constituição ${ }^{61}$.

O princípio da moralidade importa no estudo do investimento público, porque ultrapassa a mera observância da legalidade pela Administração Pública para trazer à consideração do ato administrativo os princípios éticos, a lealdade e a boa-fé. Sua observância é baseada na licitude e na probidade do ato jurídico, hipótese de crime de responsabilidade, como faz notar Celso Antonio Bandeira de $\mathrm{Mello}^{62}$. É ainda elemento a fundamentar a ação popular prevista entre os direitos e garantias fundamentais do artigo $5^{\circ}$, LXXIII da Constituição.

É oportuno, a esta altura, recordar que a boa-fé é um comando hermenêutico e uma cláusula geral do comportamento intersubjetivo na relação obrigacional, a qual faz prevalecer os interesses comuns das partes ${ }^{63}$. Corresponde a um comportamento conforme as fundadas expectativas criadas na outra parte ${ }^{64}$, de sorte a determinar a necessária previsibilidade dos atos administrativos aplicáveis aos administrados.

A eficiência será tratada mais detidamente no Capítulo 2 desta Dissertação. Esse princípio foi incluído no rol dos princípios constitucionais administrativos pela Emenda $\mathrm{n}$. 19, de 04 de junho de 1998, a qual modificou o regime jurídico e dispôs sobre princípios e

${ }^{61}$ Cf. MELLO, Celso Antonio Bandeira de. op. cit., p. 114.

${ }^{62}$ Cf. MELLO, Celso Antonio Bandeira de. op. cit., p. 119-120.

${ }^{63}$ Cf. MARTINS, Judith-Costa. Os campos normativos da boa-fé objetiva: as três perspectivas do direito privado brasileiro. In: AZEVEDO, Antonio Junqueira de; TORRES, Heleno; CARBONE, Paolo. Princípios do Novo Código Civil Brasileiro e outros temas. São Paulo: Quartier Latin, 2010, p. 409; 411, passim.

${ }^{64}$ Cf. AZEVEDO, Antonio Junqueira de. O princípio da boa-fé nos contratos. In: CONSELHO DA JUSTIÇA FEDERAL. Série Cadernos do CEJ - Centro de Estudos Judiciários, v.20, Brasília, 2002, passim. 
normas da Administração Pública. Vem inserida na tendência crítica do modo de governar e na tentativa de reforma gerencial do Estado, segundo será mencionado na análise dos aspectos históricos a conformar a estrutura do investimento público no Brasil.

De fato, o princípio da eficiência relaciona-se ao princípio geral da boa administração $^{65}$, e diz respeito ao desempenho dos atos pela Administração Pública na busca pelo melhor resultado em observância ao fim previsto constitucionalmente. Não é somente elemento econômico apreendido pelo Direito, mas um elemento a indicar a realização de um ato administrativo com “[...] presteza, perfeição e rendimento funcional"66.

A eficiência pode ser considerada no próprio desempenho da atividade administrativa ou na sua organização. É um princípio coordenado aos outros princípios constitucionais administrativos, assim como a causa eficiente coordena-se às outras causas, como será ressaltado no capítulo a seguir.

Os princípios da legalidade, impessoalidade, moralidade, publicidade e eficiência são princípios expressos, mas não exclusivos, a serem seguidos no exercício do poder administrativo. Pode-se recordar também de alguns princípios decorrentes, seja desses princípios expressos, seja de outras previsões constitucionais ou infraconstitucionais, importantes para o tratamento do investimento público, tais como a supremacia do interesse público sobre o particular, a finalidade, a razoabilidade e a motivação.

A supremacia do interesse público está ligada ao exercício do poder pela Administração Pública em relação ao privado. Uma relação jurídica estabelece-se, em geral, mediante a igualdade de posição entre as partes, na limitação balanceada da intervenção na esfera de interesses de uma parte em relação à outra. A supremacia e a desigualdade justificam-se na medida em que a Administração Pública exerça o poder para atingir a finalidade do interesse público. Porém, esse interesse público, assim como todos

${ }^{65}$ Cf. MELLO, Celso Antonio Bandeira de. op. cit., p. 122.

${ }^{66}$ MEIRELLES, Hely Lopes. Direito Administrativo Brasileiro. São Paulo: Malheiros, 2003, p. 102. 
os conceitos juridicamente previstos, é indeterminado e a Constituição sequer oferece critérios claros para sua determinação.

Conforme Celso Antônio Bandeira de Mello, a posição privilegiada e a própria supremacia do sujeito que representa o interesse público são dois princípios subordinados ao axioma supremacia do interesse público sobre o interesse privado. Aquela posição privilegiada atribui ao órgão público determinados privilégios para que assegure a proteção ao interesse público, tais como a presunção de veracidade ou os prazos especiais para atuação processual; essa posição de supremacia configura uma situação de autoridade e desigualdade, incluindo a possibilidade de modificação ou rescisão unilateral do contrato ${ }^{67}$.

A finalidade ou o princípio da finalidade justifica a atribuição e o exercício do poder. Seu desvio é fundamento da nulidade do ato; no entanto, é mais do que a mera decorrência do princípio de legalidade. Para Celso Antonio Bandeira de Mello, o princípio da finalidade

[...] é uma inerência dele; está nele contido, pois corresponde à aplicação da lei tal qual é; ou seja, na conformidade de sua razão de ser, do objetivo em vista do qual foi editada. Por isso se pode dizer que tomar uma lei como suporte para prática de ato desconforme à sua finalidade não é aplicar a lei; é desvirtuá-la; é burlar a lei sob pretexto de cumpri-la ${ }^{68}$.

Como será discutido no Capítulo 2 desta Dissertação, o resultado não é a idêntica expressão dessa finalidade, mas a Administração Pública deve buscar a consecução da finalidade no exercício de suas funções. A finalidade oferece a base para avaliação do interesse público em determinada ordem jurídica e para a análise do vício no exercício ou desvio de poder. $\mathrm{O}$ investimento público enquanto efeito do ato jurídico público, mais especificamente ato administrativo, deve ser de qualquer forma uma expressão concreta daquela finalidade abstrata prevista na Constituição. Caso contrário a Constituição será a estrutura teórica sem o rendimento efetivo, ideologia sem concretização.

${ }^{67}$ Cf. MELLO, Celso Antônio Bandeira de. op. cit., p. 69-70.

${ }^{68}$ MELLO, Celso Antônio Bandeira de. op. cit., p. 106. 
Apesar de o princípio da razoabilidade não vir expressamente arrolado no artigo 37 da Constituição Federal, é um dos princípios fundamentais na análise do investimento público enquanto efeito do ato administrativo, porque limita o ato jurídico enquanto ato discricionário e legítimo comportado pela lei. Observa a finalidade da lei e da outorga da competência à Administração Pública ${ }^{69}$ e incide na própria interpretação e aplicação da lei, na tomada de decisão de investimento público. A razoabilidade é critério de mensuração da competência da Administração Pública e da liberdade nos limites da lei, possuindo como aspecto inerente a proporcionalidade, o critério por meio do qual se exige o razoável. Nesse sentido, Celso Antonio Bandeira de Mello defende que a proporcionalidade é um aspecto específico da razoabilidade, estando associado à extensão e intensidade ao que é determinado para o atendimento do interesse público, decompondo-se em necessidade, adequação e proporcionalidade em sentido estrito ou justa medida de ponderação do ato em relação ao fim $^{70}$.

A motivação, juntamente com a finalidade, é basilar para a tomada da decisão do investimento público. Trata-se dos elementos fáticos e fundamentos jurídicos que ensejaram o ato, da justificativa clara, congruente e explícita para o exercício do poder pela Administração Pública. $\mathrm{O}$ arrazoamento apresentado na motivação do ato vincula a Administração Pública e determina toda a execução do ato de investimento público. Ressalta Celso Antonio Bandeira de Mello que a motivação deve ser detalhada e deve ser mais do que a mera menção da regra aplicada, sempre que a autoridade administrativa praticar ato discricionário ou ato vinculado do qual dependa qualquer apreciação fática e normativa ${ }^{71}$.

A lei dos processos administrativos federais (lei n. 9.784/1999) indica uma série de atos administrativos que deverão ser motivados, a saber, aqueles que neguem, limitem ou afetem direitos ou interesses; imponham ou agravem deveres, encargos ou sanções; decidam processos administrativos de concurso ou seleção pública; dispensem ou declarem a inexigibilidade de processo licitatório; decidam recursos administrativos; decorram de

\footnotetext{
${ }^{69}$ Cf. MELLO, Celso Antônio Bandeira de. op. cit., p. 108.

${ }^{70}$ Cf. MELLO, Celso Antônio Bandeira de. op. cit., p. 110-111.

${ }^{71}$ Cf. MELLO, Celso Antônio Bandeira de. op. cit., p. 110-111.
} 
reexame de ofício; deixem de aplicar jurisprudência firmada sobre a questão ou discrepem de pareceres, laudos, propostas e relatórios oficiais; ou importem anulação, revogação, suspensão ou convalidação de ato administrativo.

Considerar o investimento enquanto expressão de um ato administrativo faz com que seja classificado, nos termos da Lei 4.320/1964, como despesa de capital. A despesa de capital é a dotação orçamentária destinada, entre outros, ao planejamento e à execução de obras de infraestrutura e à realização dos programas governamentais. A despesa ou dívida pública é, portanto, gênero da espécie investimento público a abarcar o investimento enquanto despesa de capital e outras despesas, enquanto despesas correntes.

O investimento público, no entanto, pode ser tomado também sob outro enfoque, não mais de ato jurídico administrativo, porém, efeito de uma política financeira ou de um exercício de poder financeiro do Estado. Nesse sentido, parte-se de uma autonomia do direito financeiro em relação ao direito administrativo ou até mesmo ao do direito privado. A esse propósito, Aliomar Baleeiro salienta que “[...] as relações jurídicas específicas que decorrem da tributação e da despesa, a índole específica do orçamento e até as peculiaridades dos contratos de empréstimo, quando o devedor é o Estado, definem claramente a autonomia do direito financeiro",72.

Deve-se frisar que a breve menção aos princípios de direito tributário e financeiro não desnatura a linha metodológica adotada nesta Dissertação para leitura do tema proposto. $\mathrm{O}$ enfoque no efeito continua a ser parte de uma abordagem segundo a teoria geral do direito. Corriqueiramente, o Estado pode atuar ou intervir no domínio econômico, por meio de incentivo, indução, subvenção, isenção, crédito presumido e alguma espécie benefício. $\mathrm{O}$ investimento público, nesse caso, é a renúncia do agir como consequência da atividade do Estado planejador e programador a instaurar os padrões da arrecadação tributária e gerar efeitos sobre as receitas e despesas públicas e sobre os atos de terceiros.

72 BALEEIRO, Aliomar. Direito tributário brasileiro; atual. Misabel Abreu Machado Derzi, Rio de Janeiro: Forense, p. 2. 
O investimento público enquanto efeito da renúncia da arrecadação tributária exibe um caráter de extrafiscalidade no exercício das funções do Estado e decorre de um conjunto de medidas de natureza financeira, tributária e creditícia por ele tomadas. Mas qual seria a classificação do investimento no orçamento, peça principal nas finanças públicas do Estado? O investimento público, nesse caso, é uma renúncia de receita, uma receita não arrecadada. Tem-se que essa renúncia é de tal forma relevante para as questões orçamentárias do Estado, que vem expressamente disciplinada na Constituição e na Lei de Responsabilidade Fiscal (Lei Complementar n. 101/2000).

O investimento público, efeito jurídico, é um elemento obrigatório a compor o demonstrativo regionalizado que deve acompanhar o projeto de lei orçamentária. Conforme reconhecido pela própria Constituição (art. $165, \S 6^{\circ}$ ), é um efeito que incide sobre as receitas e despesas. Por seu turno, a Lei de Responsabilidade Fiscal igualmente prevê que o projeto da lei orçamentária anual, elaborado de forma compatível com o plano plurianual, a lei de diretrizes orçamentárias e as normas dessa mesma lei, será acompanhado do demonstrativo regionalizado e das medidas de compensação a renúncias de receita e ao aumento de despesas obrigatórias de caráter continuado (art. $5^{\circ}$, II).

$\mathrm{Na}$ verdade, a Lei de Responsabilidade Fiscal traz uma disciplina particular à própria renúncia de receita. Esse dispositivo preconiza que a concessão ou a ampliação de incentivo ou benefício de natureza tributária da qual decorra renúncia de receita devem estar acompanhadas de estimativa do impacto orçamentário-financeiro no exercício em que deva iniciar sua vigência e nos dois seguintes, devendo ainda atender ao disposto na lei de diretrizes orçamentárias e, ainda, a uma das seguintes condições: (i) deve ser demonstrado pelo proponente que a renúncia foi considerada na estimativa de receita da lei orçamentária e que não afetará as metas de resultados fiscais previstas pela lei de diretrizes orçamentárias; e (ii) deve estar acompanhada de medidas de compensação, por meio do aumento de receita, proveniente da elevação de alíquotas, ampliação da base de cálculo, majoração ou criação de tributo ou contribuição. Se o ato de concessão ou ampliação do incentivo ou benefício decorrer desta última condição mencionada, o benefício só poderá entrar em vigor quando da tomada de medidas compensatórias. 
Apesar de não se aplicar às alterações das alíquotas dos impostos sobre importação, impostos sobre exportação, impostos sobre produtos industrializados (IPI) e impostos sobre operações de crédito, câmbio e seguro, ou relativas a títulos ou valores mobiliários (IOF) (art. 157, $\S 1^{\circ}$ da Constituição), as condições e limitações infraconstitucionais da Lei de Responsabilidade Fiscal parecem esboçar um tratamento financeiro mais restritivo e vinculativo ao Estado do que a própria Constituição, ainda que considerado constitucional pelo Supremo Tribunal Federal. Pode-se afirmar que a edição da Lei de Responsabilidade Fiscal limitou em grande medida a forma de agir da Administração Pública, que deve compensar um não agir, a menor entrada de receitas públicas, por meio ou da diminuição das despesas ou pelo aumento da arrecadação ou da entrada em outro setor. E não são todas as entradas nos cofres públicos a serem consideradas receitas públicas, mas tão somente as entradas novas e de caráter permanente, não sujeitas à devolução.

Enquanto efeito da renúncia do agir, diz respeito ao tratamento dos princípios em matéria tributária e financeira. As normas aplicáveis ao investimento público em matéria tributária consistem em toda uma série de normas destinadas ao legislador (como no caso do crédito público) ${ }^{73}$. São princípios e limitações ao exercício da competência legislativa. Vale ressaltar na matéria, para consideração do investimento público enquanto efeito da renúncia de arrecadação tributária, principalmente, o princípio da reserva de lei ou da legalidade estrita, o princípio da isonomia ou igualdade tributária, o princípio da capacidade contributiva, o princípio da irretroatividade tributária, o princípio da anterioridade e o princípio da uniformidade tributária.

O princípio da reserva de lei ou da legalidade estrita em matéria tributária é um elemento de segurança jurídica e veda exigir ou aumentar tributo sem lei que o estabeleça (art. 150, I). Sua análise é fundamental em vista da necessidade de equilíbrio fiscal entre o investimento público - despesa pública - e a respectiva arrecadação de tributo; também das condições e compensações impostas para as renúncias de receitas.

${ }^{73}$ Cf. ATALIBA, Geraldo. Empréstimos públicos e seu regime jurídico. São Paulo: Revista dos Tribunais, 1973, p.34. 
Esse princípio pressupõe ainda uma limitação formal, pois a lei não se confunde com a medida provisória ou com a lei delegada. As medidas provisórias são aquelas adotadas pelo Presidente da República em caso de relevância e urgência e com força de lei, submetidas ao Congresso Nacional. As leis delegadas são aquelas elaboradas pelo Presidente da República em decorrência da delegação do Congresso Nacional. Ora, as medidas provisórias e as leis complementares não podem dispor de matéria de lei complementar, o que incluiria matéria financeira e tributária (artigos $62, \S 1^{\circ}$, III e $68, \S 1^{\circ}$, III da Constituição vigente).

A Constituição abre uma exceção, no entanto, em matéria tributária e prevê a alteração das alíquotas, por meio de decretos, dos impostos sobre importação, sobre exportação, sobre produtos industrializados, sobre operações de crédito, câmbio e seguro, ou relativas a títulos ou valores mobiliários (artigo 153, §1 ${ }^{\circ}$ ). Além disso, possibilita a instituição e majoração dos impostos por meio de medida provisória, desde que seja transformada em lei pelo Congresso no exercício seguinte $\left(\operatorname{artigo} 62, \S 2^{\circ}\right)$. Exclui desta última exigência a majoração dos impostos acima mencionados e a instituição ou majoração de impostos na iminência ou no caso de guerra externa, impostos extraordinários, compreendidos ou não em sua competência tributária, os quais serão suprimidos, gradativamente, cessadas as causas de sua criação.

O princípio da isonomia ou da igualdade tributária veda a instituição de tratamento desigual entre contribuintes que se encontrem em situação equivalente. $\mathrm{Na}$ arrecadação tributária para o exercício do poder fiscal do Estado, é fundamental a observância deste princípio, o qual, segundo José Afonso da Silva, coincide com a própria igualdade em sentido jurídico, que determina a identidade de regime fiscal e se soma ao princípio da capacidade contributiva que se baseia na igualdade em sentido econômico ${ }^{74}$.

Por sua vez, o princípio da capacidade contributiva é limitado pelo princípio do não confisco (Artigo 150, IV). Rege-se em termos constitucionais do artigo 145, §1 ${ }^{\circ}$, para o qual,

\footnotetext{
${ }^{74}$ Cf. SILVA, José Afonso da. op. cit., p. 713.
} 
[...] sempre que possível, os impostos terão caráter pessoal e serão graduados segundo a capacidade econômica do contribuinte, facultado à administração tributária, especialmente para conferir efetividade a esses objetivos, identificar, respeitados os direitos individuais e nos termos da lei, o patrimônio, os rendimentos e as atividades econômicas do contribuinte.

Com efeito, consiste na expressão da igualdade em sentido econômico e na personalização dos impostos ${ }^{75}$ na contribuição de cada um para a manutenção das despesas públicas.

O princípio da irretroatividade tributária e o princípio da anualidade ou da anterioridade são expressões da limitação de caráter temporal na arrecadação tributária (artigo 150, III da Constituição). O princípio da irretroatividade tributária trata da vedação à cobrança de tributos em relação a fatos geradores ocorridos anteriormente ao início da vigência da lei que os houver instituído ou aumentado. O princípio da anualidade ou da anterioridade veda a cobrança no mesmo exercício financeiro em que haja sido publicada a lei que instituiu ou aumentou o tributo e antes de decorridos noventa dias da data em que haja sido publicada a lei que o instituiu ou aumentou. A relevância desses princípios para a matéria dos investimentos públicos continua a ser ligada ao equilíbrio entre as receitas e as despesas, nas finanças públicas.

Em matéria de limitação temporal das normas tributárias, é interessante notar que, em algumas Constituições, já se diferenciaram a instituição e a cobrança tributária, especificando-se inclusive um critério de subordinação da lei tributária no que tange à lei orçamentária, por meio da necessária e prévia autorização na lei orçamentária da própria arrecadação da receita pública instituída em matéria tributária. A Constituição de 1988 não impôs essa subordinação da lei tributária à autorização da lei orçamentária, a despeito de haver estabelecido que a cobrança fosse feita somente a fatos geradores ocorridos após o início da vigência da lei e decorridos noventa dias da data em que haja sido publicada a lei a qual instituiu ou aumentou o tributo, salvo exceções constitucionalmente previstas.

\footnotetext{
${ }^{75}$ Ibidem.
} 
Seria de se considerar, talvez, uma retomada da tentativa de coordenação da arrecadação tributária em relação às necessidades de despesas públicas, inclusive de investimentos. Pode ser que essa medida seja mais condizente a uma análise qualitativa da responsabilidade fiscal e da efetividade e eficiência do investimento público, em contraposição à atual imposição numérica que predomina no exame das finanças públicas, no Brasil. Apesar disso, não se pode negar que o dispositivo jamais foi capaz de limitar a excessiva e histórica imposição de carga tributária ao contribuinte e o mau uso do dinheiro público, na ordem brasileira.

Quanto à limitação espacial ao exercício do poder tributário pela Administração Pública, cumpre ressaltar o princípio da territorialidade e o princípio da uniformidade tributária. O primeiro determina que a norma tributária terá sua eficácia restrita à jurisdição do ente da Administração Pública que a instituiu, contudo, no plano dos efeitos, não tem funcionado assim. Com as recentes reduções de impostos pela União para questões de incentivo tributário e setorial (vide, por exemplo, as reduções da incidência do IPI sobre veículos automotores), foram relatadas pelos Municípios dificuldades na observância dos critérios de responsabilidade fiscal devido às reduções de repasses dos Fundos de Participação dos Municípios (artigo 159).

O princípio da uniformidade geográfica (artigo 151 da Constituição) é uma limitação imposta à União, importante em matéria investimento público. Proíbe à União instituir tributo que não seja uniforme em todo o território nacional ou que implique distinção ou preferência de um ente em detrimento de outro. Admite, todavia, a concessão de incentivos fiscais destinados a promover o efeito do desenvolvimento socioeconômico entre as diferentes regiões do País. A possibilidade de tratamento diferenciado na aplicação do princípio da uniformidade geográfica federal permite a execução de uma política físcal niveladora de desigualdades regionais ${ }^{76}$, com possíveis consequências em relação aos investimentos públicos enquanto efeitos decorrentes da atuação ou intervenção do Estado.

\footnotetext{
${ }^{76}$ Cf. SILVA, José Afonso da. op. cit., p. 717.
} 
Quanto à matéria financeira, é importante ressaltar principalmente o equilíbrio fiscal, sobre o qual já se tratou brevemente, na necessidade de contenção das despesas pelos padrões de receita pública. É preciso ainda verificar a relação entre a estrutura e conjuntura, tendo em conta que estão nas finanças públicas os padrões mediadores próprios da dinâmica econômica e os critérios para aperfeiçoar a gestão que impõem uma distribuição ótima entre recursos da iniciativa privada e da atuação estatal ${ }^{77}$.

\section{Sobre a decisão do investimento público}

A decisão do ato jurídico é tomada em vista dos seus efeitos, sendo um pressuposto do próprio ato. Nessa perspectiva, o investimento público é decorrência desse pressuposto do ato jurídico. Tal afirmação põe em evidência a própria decisão do ato como parte do exercício do poder. Caso provoque a alteração de uma situação jurídica, ou seja, um efeito jurídico de investimento público, deve observar todos os princípios constitucionais a determinar a atuação do Estado em seu agir ou em sua renúncia de agir.

Se a discussão teórica que se propõe é rara e pouco difusa, também o é a cultura de avaliação dos critérios a sustentar a decisão do investimento público e o uso apropriado de técnicas disponíveis para tanto. Todos os aspectos técnicos e critérios adotados estão sujeitos à interpretação segundo a função e a observância dos fins. Na discussão sobre os critérios de investimento do Estado, devem ser levados em conta dois fatores: o modo de atuação do Estado na esfera econômica e a inadequação do uso dos elementos da teoria da empresa a interpretar e conduzir as ações estatais. Antes de uma análise mais geral do investimento enquanto efeito, é oportuno atentar-se para os aspectos técnicos da própria decisão de investimento, quer dizer, para os critérios de escolha de um determinado projeto $^{78}$.

A decisão do investimento público é o resultado de um processo de avaliação que deve levar em conta vários elementos de custos e benefícios sociais. Entretanto, a fórmula

\footnotetext{
${ }^{77}$ Cf. VIDIGAL, Geraldo Camargo. Teoria Geral... op.cit. p. 99-100, passim.

${ }^{78}$ Cf. ALLIONE, Miro. Qualche consideraizone introduttiva sui criteri di scelta degli investimenti effetuati dallo Stato. In: ALLIONE, Miro (Coord.). Le decisioni di investimento pubblico. Milão: Franco Angeli, 1971, p. 11, passim.
} 
que associa as variáveis de custos e benefícios pode ser aplicada de dois modos: no classificar os projetos de acordo com uma diferença (geralmente quantitativa) entre os rendimentos (benefícios) e os custos; e no classificar os projetos segundo a comparação das diversas relações estabelecidas entre os custos e os benefícios. Evidentemente, a análise da segunda relação é preferível à primeira ${ }^{79}$, já que permite uma avaliação valorativa e qualitativa.

Vê-se que o problema está justamente no modo de determinar a avaliação discricionária do Estado, na tomada de sua decisão. Em todo o caso, o comportamento racional, a escolha individual, os custos e os benefícios privados diferem enormemente dos custos e dos benefícios sociais, ainda que os atuais modelos teóricos de avaliação da decisão pública tentem impor modelos de avaliação e gerenciamento privados. Os benefícios sociais devem ser avaliados conforme condição específica do país e podem ser considerados na medida em que refletirem, de qualquer maneira, um incremento da renda nacional, como definida no Capítulo 2, somada ao incremento da sua distribuição e do incremento líquido total sobre a balança de pagamentos ${ }^{80}$. Em acréscimo, dos critérios qualitativos de desenvolvimento humano e bem-estar social resultantes dessa escolha.

Compatibilizada com os princípios constitucionais aplicáveis ao investimento público, não se admite na decisão do investimento público a desproporção entre o valor gasto e os resultados alcançados, a presença de custos exorbitantes em relação aos benefícios auferidos, os longos períodos de execução e a desnaturação da finalidade, na realização do investimento público. O processo de investimento público, da tomada de decisão à execução e controle do resultado e do cumprimento da finalidade, não admite a má utilização do patrimônio público, a escolha da nítida e insuficiente qualidade em razão do menor preço, o abandono da obra, o sucateamento e sua má-gestão, a falta de domínio técnico na avaliação da qualidade do investimento. Tudo isso sem mencionar a corrupção e qualquer forma de desvio de dinheiro público aos interesses privados.

\footnotetext{
${ }^{79}$ Esses dois critérios de comparação entre custos e benefícios na escolha do investimento são ressaltados por Augusto Graziani, ao discutir os critérios de custos e benefícios e os critérios de rendimento interno. Cf. GRAZIANI, Augusto. La teoria delle scelte negli investimenti pubblici. Nápoles: Jovene, 1961, p. 177.

${ }^{80}$ Cf. CHENERY, Hollis B. L'applicazione di criteri d'investimento. In: ALLIONE, Miro (Coord.). Le decisioni di investimento pubblico. Milão: Franco Angeli, 1971, p. 125-126, passim.
} 
De qualquer maneira, não se pode restringir o investimento público aos efeitos imediatos e quantificáveis da decisão. Tampouco se pode tomar a alocação de recursos somente com base nos resultados expressados na maximização do produto nacional, tida por muitos o modo alocação eficiente ${ }^{81}$. Deve ser possível individuar juridicamente a base da decisão de tipo estatal, fundamentando-se na aplicação de princípios os quais levem ao alcance do efeito desenvolvimento.

Ademais, a decisão de investimento público não pode ser confundida com a decisão de investimento privado. Não basta para a decisão de investimento público, conforme entendimento de José Tadeu De Chiara, uma discussão de rentabilidade, segurança e liquidez, nos moldes feitos na decisão de investimento privado ${ }^{82}$. Assim sendo, pensar o Estado como uma empresa que deve assumir uma posição gerencial é, no mínimo, superficial. Deixa de considerar as peculiaridades que a qualificação "público" impõe, o que vem a contrapor parte da doutrina da economia do setor público, a qual toma como critério a análise formal, particular e estática, em moldes privados, da decisão do investimento público, deixando de verificar os efeitos da decisão na dinamicidade da objetivação da função estatal.

Toda a discussão será retomada na análise da eficiência, mas já se podem vislumbrar quantos dos casos acima citados estão presentes no investimento público realizado em nosso país. Antes de qualquer exame da função e do plano dos efeitos, já se pode preliminarmente aventar o descumprimento de tantos princípios constitucionais. $\mathrm{E}$ vale recordar que foram esses mesmos problemas usados como justificativa para a privatização pela própria Administração Pública. O problema era efetivamente um público ineficiente, a atrapalhar o funcionamento dos mecanismos para alcance desenvolvimento, ou o caso era de responsabilização e de improbidade dos agentes da Administração Pública? Essa questão será retomada no tratamento a ser feito a seguir.

${ }^{81}$ Cf. GALENSON, Walter; LEIBENSTEIN, Harvey. Criteri d'investimento, produttività e sviluppo economico. In: ALLIONE, Miro (Coord.). Le decisioni di investimento pubblico. Milão: Franco Angeli, 1971, p. 148, passim.

${ }^{8}$ Cf. DE CHIARA, José Tadeu. Aulas... op.cit. 


\subsection{Elementos estruturais do investimento público no Brasil: aspectos históricos e regime jurídico}

Os elementos estruturais do investimento público no Brasil consideram seus aspectos históricos e toda a caracterização de seu regime jurídico. Esses elementos estruturais configuram-se em premissas para sua realização, nas características da decisão de agir ou de abstenção de agir a produzir o investimento público e no próprio investimento público enquanto efeito. A estrutura vem delineada em um regime jurídico de determinada ordem jurídica. Ora, o regime jurídico é nada mais do que um modo de funcionamento, um conjunto de prescrições que caracterizam o exercício do poder pelo sujeito de direito.

A disciplina do investimento público, portanto, será tratada a partir de sua principal norma, a constitucional, a qual prevê não só as premissas e finalidades da decisão do investimento público (princípios e objetivos da ordem jurídica brasileira), como também a base do modo de atuação do principal sujeito de direito a exercitá-la (Administração Pública).

A análise da decisão pública de investir requer o exame da sua realidade concreta e específica. Seu exame é produto da História e da orientação do intérprete. Seguindo o ensinamento de Tullio Ascarelli,

[...] qualquer ordenamento jurídico, ainda que esteja na História e seja fruto da História, apresenta, por isto, avaliações diferentes historicamente, devido às diferentes forças que contribuem para determiná-lo e para determinar os seus contrastes. A coerência lógica do sistema e a compatibilidade das suas diversas premissas não dizem respeito à sua formação histórica; são fruto da História e fruto de trabalho sempre transitório do intérprete, por meio da avaliação e, portanto da ordem, de suas várias orientações e delimitações do alcance das várias premissas da interpretação. ${ }^{83}$

\footnotetext{
${ }^{83}$ ASCARELLI, Tullio. Studi..., op. cit., p. 13.
} 
A verificação jurídica desse regime deve partir da análise do próprio Estado brasileiro. Bem ressalta Alberto Venâncio Filho que "[...] a natureza da legislação de intervenção do Estado no domínio econômico não pode, porém, prescindir do exame das características do Estado brasileiro e da forma pela qual está preparado para dar cumprimento a essa função" $"$.

Por meio da significação histórica do investimento público, no Brasil, busca delinear os estágios e as tentativas de superação conjuntural e estrutural do subdesenvolvimento. O investimento público, nesse sentido, é estudado com base em um conjunto específico de princípios e na forma específica de atuação do Estado. Fortemente ligada aos interesses de um grupo predominante, a atuação do Estado na ordem jurídica brasileira vem a determinar a forma da própria ordem social.

A ordem social disciplina a convivência humana ${ }^{85}$ e o modo de se relacionar dos sujeitos. É uma realidade ontológica, assim como é uma realidade cognitiva; uma ordem teórico-conceitual, mas igualmente uma ordem concreta. Trata-se de um produto da coordenação de interesses e de funções, e deve se fundamentar estruturalmente no bem comum. Assumida a ordem social como um sinônimo de ordem pública, esta pode ser tomada como um fim do ordenamento ou uma circunstância de fato ${ }^{86}$.

As considerações teóricas e factuais não podem ser confundidas. Em uma análise semiótica, jamais se pode identificar a realidade social, ela mesma, objeto real, à realidade interpretada e à realidade expressa em palavras, em nossa Constituição. Na letra, no seu significante, temos uma estrutura cuja prática não segue. É o idealismo constitucional, de Oliveira Vianna; a folha de papel que não se faz real, de Ferdinand Lasalle.

\footnotetext{
${ }^{84}$ VENANCIO FILHO, Alberto. A intervenção do Estado no domínio econômico, Rio de Janeiro: FGV, 1968 , p. 35.

85 TELLES Jr., Goffredo da Silva. A criação do direito. São Paulo: Juarez de Oliveira, 2004, p. 476.

${ }^{86}$ VERGOTTINI, Giuseppe. Ordem pública. In: BOBBIO, Norberto; MATTEUCCI, Nicola; PASQUINO, Gianfranco. Dicionário de política. Brasília: Ed. UnB, 2007, p. 851.
} 
Os juristas, nesse contexto, captam não somente uma realidade existente, mas a estabelecem a partir das previsões normativas e dos princípios que ele mesmo interpreta. A realidade - produto da interpretação - "é e não é dado interpretado", conforme lição de Tullio Ascarelli ${ }^{87}$. Esse modo de manifestar o conhecimento não significa reduzir o mundo a um conjunto de ideias. No processo de construção da ordem social, o jurista é colocado em foco na construção da própria realidade.

\section{Breves acenos históricos}

Tracemos uma significação histórica do investimento público, no Brasil. O início da História do Brasil, o que se entende pelo período logo após a sua descoberta, tem no investimento privado a base para a proteção e desenvolvimento da terra colonizada. O sentido da colonização, ou melhor, seu fim não é outro que o abastecimento do comércio europeu de produtos de monocultura e extrativismo ${ }^{88}$. São os exploradores, os extrativistas e os primeiros monocultores donatários de capitanias hereditárias a investir na terra descoberta. No entanto, a vastidão do território torna insuficiente e precária a colonização por meio de decisões de investimento privado ${ }^{89}$, de sorte que o território sofre uma série de tentativas de invasão e apropriação estrangeira, durante os séculos XVI e XVII.

Esboça-se já nesse período colonial, apesar do enfoque da administração enquanto arrecadação tributária, um regime de ineficiência no manejo das finanças públicas com permanente déficit na administração colonial, além do forte domínio da corrupção em todas as esferas administrativas ${ }^{90}$.

No século XVIII, observa-se o começo de uma alteração na administração das terras conquistadas, produto da descoberta do ouro na região das Minas Gerais (fim do século XVII) e da fixação das fronteiras entre as terras colonizadas por Portugal e Espanha, por meio do Tratado de Madrid de 1750. A produção agrícola do país passa a adentrar ao

\footnotetext{
${ }^{87}$ ASCARELLI, Tullio. Antigone e Porzia in Rivista Internazionale di Filosofia del Diritto, 1955, n. 756, agora in: Problemi giuridici, Vol. I, Milão: Giuffrè, p. 147 e ss., 1959, p. 156.

${ }^{88}$ Cf. PRADO Jr., Caio. Formação do Brasil Contemporâneo. São Paulo: Brasiliense: Publifolha, 2000, p.117.

${ }^{89}$ Cf. PRADO Jr., Caio. Evolução Política do Brasil: colônia e império. São Paulo: Brasiliense, 2007.

${ }^{90}$ Cf. PRADO Jr., Caio. Formação... op. cit., 2000, p.340-341; 343, passim.
} 
interior, seguindo o movimento da agricultura paulista, quando dois tipos de agricultura são observados: aquela de subsistência e a produção em grande escala de açúcar, algodão e tabaco ${ }^{91}$. Na expressão de Caio Prado Jr., esses são "[...] os fundamentos da agricultura colonial" 92 .

Observa-se uma forte intervenção do Ministro de Dom José I, o Marquês de Pombal (1750-1777), que transforma as capitanias hereditárias em capitanias da Coroa portuguesa e cria duas importantes concessionárias do monopólio do comércio, as Companhias de Comércio no Brasil (a Companhia de Comércio do Grão-Pará e Maranhão e a Companhia Geral de Comércio de Pernambuco e da Paraíba). Em acréscimo, convém lembrar o Alvará de D. Maria I (1785) que proíbe a produção de manufaturas têxteis no Brasil, "[...] golpe de morte na indústria da colônia" 93 .

Não se pode esquecer que foi essa forte intervenção portuguesa - que muito retirava das terras conquistadas e pouco oferecia ao seu progresso e desenvolvimento - a causa de uma série de rebeliões populares e de movimentos de emancipação, no período colonial. Mencionam-se, entre outras, sem preocupações com seu detalhamento, a Insurreição Pernambucana (1645-1654), a Guerra dos Mascates (1710), a Revolta de Vila Rica (1720), a Inconfidência Mineira (1789) e a Conjuração Baiana (1798).

Aliás, esse modo de intervenção português e a forma de organização e exploração das atividades econômicas, no Brasil colonial desse período, continuavam a se desenvolver em função do abastecimento da metrópole e do comércio europeu. Como enfatiza Caio Prado Jr., “[...] são atividades que se desenvolvem à margem de necessidades próprias da sociedade brasileira" 94 .

Após esse período, a crise do Antigo Regime e do Antigo Sistema Colonial e a fuga de D. João VI ao Brasil fazem da colônia a sede da monarquia portuguesa, momento no

\footnotetext{
${ }^{91}$ Cf. PRADO Jr., Caio. Formação... op. cit., p.133; 138; 146-150.

92 PRADO Jr., Caio. Formação... op. cit., p.151.

${ }^{93}$ PRADO Jr., Caio. Formação... op. cit., p.231.

${ }^{94}$ PRADO Jr., Caio. Formação... op. cit., p.171.
} 
qual se pode apontar talvez algum progresso na estrutura econômico-social, na criação de uma estrutura burocrática e de infraestrutura, com a revogação da proibição da produção manufatureira têxtil e o incentivo à produção do ferro ${ }^{95}$, a fim de atender aos interesses da família real e da aristocracia portuguesa.

A volta da família real a Portugal, em 1821, e o estabelecimento do Reinado de D. Pedro I (1822-1831) impõe ao país o primeiro grande endividamento público para o reconhecimento da sua independência, por meio do qual assume a dívida portuguesa com a Inglaterra e toma como decisão de despesa pública a primeira das muitas decisões representativas de um interesse contrário ao bem comum e à ordem pública, a prejudicar o desenvolvimento do país. Entretanto, esta seria a primeira de tantas decisões de uma política econômica fadada ao fracasso. É nesse tempo que são contraídos outros tantos empréstimos com a Inglaterra, não revertidos aos interesses da Nação. Tais empréstimos são também consequência de um mal estruturado sistema de arrecadação tributária, incapaz de recolher os meios necessários à manutenção do governo, que busca financiar os débitos por meio da grande emissão do papel-moeda e da desvalorização da moeda com um aumento relativo dos preços de produtos de importação ${ }^{96}$.

A nova ordem social vem estruturada em uma Constituição outorgada (1824) de um Brasil independente, censitário, com forte política repressiva e centralizadora do Imperador. A abdicação de D. Pedro I, em 1831, leva ao estabelecimento do período regencial (1831-1840), com a criação de guardas nacionais (1831), a promulgação do Código de Processo Criminal (1832) e o estabelecimento de um Ato Adicional à Constituição de 1824, que fortalece a descentralização do poder central e o aumento do poder das províncias, autonomia esta suprimida na Reação Conservadora. O que se pode observar é um contexto de enorme disputa de poder político entre os ditos liberais e conservadores e de numerosas rebeliões no país contra a imposição, pelo governo central, dos presidentes das províncias. Apenas a título de recordação, podem-se citar diversas revoltas, como a Revolução Farroupilha (1835-1845), a Cabanagem (1835-1836), a

${ }^{95}$ Cf. PRADO Jr., Caio. Formação... op. cit., p.231.

${ }^{96}$ Cf. FURTADO, Celso. Formação econômica do Brasil. São Paulo: Companhia Editora Nacional: Publifolha, 2000, p. 102-103. 
Sabinada (1837), a Balaiada (1838-1841), as revoltas liberais em São Paulo e Minas Gerais (1842) e a Revolução Praieira, em Pernambuco (1848).

Não se pode nem mesmo vislumbrar, nesse período regencial, a existência de uma atividade estatal que tivesse como consequência um investimento público a viabilizar o progresso ou o desenvolvimento social, no país. Na economia e ordem social latifundiária, predominam os interesses do investimento em uma infraestrutura mínima para escoamento da produção de monoculturas, via exportação.

O Segundo Reinado (1840-1889) impõe-se com base nessa estrutura social censitária de grandes latifundiários detentores da riqueza decorrente da exportação de produtos agrícolas. O café transforma-se no principal produto de exportação, sendo sua produção desenvolvida por meio do intenso uso da terra e da mão de obra escrava ${ }^{97}$, e, no que concerne à política, são os interesses dos grandes latifundiários, na prática parlamentar, a deflagrar uma política protecionista da produção nacional, com imposição de sobretaxa aos produtos importados (tarifa Alves Branco - 1844).

O movimento liberal e a abolição da escravatura levam à substituição da mão de obra escrava pela mão de obra imigrante (após 1850, com a proibição do tráfico negreiro, pela Lei Eusébio de Queiroz). Inicialmente patrocinada pelos particulares, a imigração torna-se uma servidão disfarçada, com a consequente proibição da emigração pelos países europeus, por volta de 1850 . Tal proibição conduz ao estabelecimento de uma subvenção governamental da imigração e à regulamentação da condição de trabalho dos imigrantes, para atrair mão de obra (1870). Aos imigrantes, em sua maioria de origem italiana, são garantidos gêneros de primeira necessidade, gastos com transporte, instalação e uma renda futura $^{98}$.

Em âmbito econômico, verificam-se graves problemas na gestão do sistema fiscal e uma política monetária desastrosa a provocar graves desequilíbrios internos. Explica Celso Furtado:

${ }^{97}$ Cf. FURTADO, Celso. Formação... op.cit., p. 118-119.

${ }^{98}$ Cf. FURTADO, Celso. Formação... op.cit., p. 133. 
[...] A forma de operar do sistema fiscal merece particular atenção, pois, se por um lado contribuía para reduzir o impacto das flutuações externas, por outro lado agravava o processo de transferência regressiva da renda nas etapas de depressão. $O$ fato de que se reduzisse a carga fiscal ao depreciar-se a moeda - isto é, nas etapas em que os preços dos produtos exportados baixavam no mercado internacional - operava evidentemente como um fator compensatório da pressão deflacionária externa. Sem embargo, a redução da carga fiscal se fazia principalmente em benefício dos grupos sociais de rendas elevadas. Por outro lado, a cobertura dos déficits com emissões de papel moeda criava uma pressão inflacionária, cujos efeitos imediatos se sentiam mais fortemente nas zonas urbanas ${ }^{99}$.

A atuação monárquica, daquilo que se pode notar, não traz nenhuma grande contribuição ao desenvolvimento do país e se mantém muito vinculada aos interesses privados dos grandes proprietários de terra. Com o advento da República e de um novo regime constitucional, o voto censitário é abolido e garantido de modo universal a todos os homens maiores de 21 anos. O governo republicano passa a ser presidencialista e federalista, com três poderes independentes. A despeito de a substituição da Monarquia pela República continuar a expressar a prevalência dos interesses de um determinado grupo social, começa-se a discutir no país a ideia liberal de progresso e a se tomar diversas decisões de política pública, monetária, fiscal e econômica.

Nessa perspectiva, a mudança do regime político, sob a égide dos ministros Visconde de Ouro Preto e Rui Barbosa, possibilita a adoção de uma política econômica com fomento à industrialização e de uma política monetária com abundante emissão de moeda, para incentivar a oferta de crédito, o aumento da negociação de títulos privados e da especulação nas bolsas de valores. E mais, trata da aprovação de uma nova legislação bancária.

Não se pode vislumbrar, nesse conjunto, uma política de investimento público. A mera criação de papel-moeda e o aumento do crédito ao setor privado não podem ser tidos aqui como uma política específica de investimento público, ainda que, sem dúvida, sejam medidas de política conjuntural. Não se observa, nessa política, uma atividade administrativa que vise aos efeitos de investimento, renda ou ao desenvolvimento.

\footnotetext{
${ }^{99}$ FURTADO, Celso. Formação... op.cit., p. 174.
} 
Essa decisão de política econômica, ou melhor, de política monetária, leva a um aumento desenfreado da inflação e da especulação nas bolsas de valores, causando uma forte crise econômica (a conhecida crise do encilhamento). Campos Sales (1898-1902) é obrigado então a realizar um alto endividamento externo para debelar a crise, impondo uma política deflacionária e de congelamento de créditos e salários, com o aumento da arrecadação tributária e a criação de novos impostos, o que também não se traduz em uma política de investimento público. O apoio e a sustentação dessas medidas levam ao estabelecimento da Política do Café com Leite, com a consolidação das oligarquias estaduais de São Paulo e Minas Gerais.

Rodrigues Alves (1902-1906) é o primeiro governo republicano a estabelecer uma política de investimento público para urbanização da capital do Rio de Janeiro e para sua assistência sanitária (campanhas de saneamento e higienização de Oswaldo Cruz). Obviamente, essa política, como grande parte das políticas públicas instauradas na história do Estado brasileiro, está marcada por uma série de interesses da elite dominante na capital. Diversos foram os benefícios na eliminação dos cortiços e reformulação da cidade, porém, sem dúvida, não buscavam salvaguardar os interesses da população pobre expulsa das áreas centrais. Como bem ressalta José Murilo de Carvalho,

[...] outra indicação de ambiguidade era a relação da modernidade com a ideia de civilização. Quando se dizia que o Rio se civilizava, a expressão indicava antes uma aristocratização da vida urbana do que sua democratização. Indicava a criação de um espaço urbano para as elites, afastando a presença deselegante da pobreza ${ }^{100}$.

Uma segunda política de investimento público iniciada por Rodrigues Alves é a Política de Valorização do Café. O governo passa a investir na compra de estoques de café para a manutenção do preço de venda, no mercado internacional. Essas políticas de intervenção governamental para garantir a rentabilidade do café são feitas por meio do

${ }^{100}$ CARVALHO, José Murilo de. Brasil 1870-1914: a força da tradição. In: Pontos e bordados: escritos de história e política. Belo Horizonte: Ed. UFMG, 2005, p. 116. 
estabelecimento do empréstimo externo para custear a compra do café e por meio da estabilização do valor da moeda brasileira ${ }^{101}$.

A partir do governo de Afonso Pena (1906-1909), cria-se também uma Caixa de conversão para as divisas provenientes da exportação do café, com a utilização de uma taxa de câmbio desvalorizada. Tal política demonstra um alto comprometimento das decisões de investimento público aos interesses de uma elite latifundiária e cafeicultora, atitude que nenhum benefício trazia ao interesse geral e ao bem comum. Ao contrário, avantajava uma parcela da população que se beneficiava dessa política para produzir ainda mais café e auferir ainda mais lucros com o incentivo governamental.

A política de incentivo governamental ao café leva a um aumento do endividamento público interno, à necessidade de um segundo saneamento das contas públicas e à contração de uma nova dívida externa com a Inglaterra, no governo de Wenceslau Brás. Mas é certo que o excesso de produção de café, em decorrência da equivocada decisão de investimento público, vem inserido em um contexto de crise social e de valores que se caracteriza na própria crise do governo republicano (crise da República Velha), iniciada no governo de Epitácio Pessoa.

Washington Luís, baseado no lema de Afonso Pena "governar é povoar", governa o Estado de São Paulo sob o lema "governar é abrir estradas"; impõe também grande repressão do movimento operário. Seu lema poderia ser levado ao âmbito federal e ser visto como indicativo do direcionamento das decisões políticas feitas por governos posteriores. Contudo, no auge da crise da República Velha, Washington Luís mantém uma política de conjuntura, com a Política de Valorização do Café, o câmbio elevado e o favorecimento das exportações incentivadas.

O desenvolvimento na construção da nação republicana é o resultado de uma ideia de progresso, o qual se inclui no desenvolvimento, mas com ele não se confunde. No

${ }^{101}$ Cf. FAUSTO, Boris. História do Brasil. São Paulo: EDUSP, 2012, p. 229. 
entanto, era comum a identificação entre a ideia de desenvolvimento e progresso. Nesse sentido, Goffredo da Silva Telles:

[...] O desenvolvimento tem caráter ascensional, porque o novo, saído do velho, é superior a este, como trinta grãos de cevada são superiores a um só. O desenvolvimento é marcha do mais simples para o mais complexo, do inferior para o superior. É movimento ascendente. É, precisamente, o que se chama progresso ${ }^{102}$.

O progresso desse período baseia-se na ideia de modernização e burocratização do Estado, muito influenciada pelas teorias sociais discutidas na Europa, as quais passam a ser predominantes no modelo de desenvolvimento político proposto pós-segunda guerra mundial. Com bases teóricas em um funcionalismo estrutural, a teoria da modernização defende o desenvolvimento como "[...] um inevitável e evolucionário processo de crescimento de diferenciação social, o qual produziria, em última instância, instituições econômicas, políticas e sociais semelhantes àquelas no Ocidente" ${ }^{\text {"103. }}$

Como destaca Thomas Skouteris, “[...] as narrativas do progresso sempre dão poder a uns e tiram o poder de outros. Revelar as exclusões das narrativas de progresso e contestar seu exclusivo direito de explicar o mundo 'como ele é', no entanto, é a ação. Abre o campo para histórias e registros alternativos de progresso"104.

Com a Revolução de 1930, assume Getúlio Vargas (1930-1945) e promove a dissolução dos governos estaduais e a manutenção de uma Lei Orgânica a disciplinar as atribuições governamentais. Observa-se ainda uma forte dominação da tradição agrícola e de interesses patrimoniais dos grandes proprietários rurais, apesar da tendência de industrialização e modernização do país. Cria o Departamento Nacional do Café (DNC) promovendo, então, “[...] a federalização da política cafeeira" ${ }^{105}$.

\footnotetext{
${ }^{102}$ TELLES Jr., Goffredo da Silva. O direito quântico. São Paulo: Max Limonad, p. 94.

${ }^{103}$ TAMANAHA, Brian Z. As lições dos estudos sobre direito e desenvolvimento. Revista DireitoGV, n. 9, trad. Tatiane Honório Lima, ver. José Rodrigo Rodrigues, São Paulo, p. 187-196, jan.-jun-2009.

${ }^{104}$ SKOUTERIS, Thomas. The notion of progress in International Law Discourse. Haia: T.M.C. Asser Press, 2009, p.229.

${ }^{105}$ FAUSTO, Boris. op.cit., p. 285.
} 
Após a Revolução Constitucionalista de 1932, Getúlio Vargas promulga a Constituição de 1933 e passa a buscar o progresso baseado em um programa de renovação conservadora das bases produtivas, sem a presença do povo pobre, negro e analfabeto na sua conformação. Como resultado do período anterior de 1870 a 1914, combina repressão e paternalismo no tratamento dos indivíduos, com a forte consolidação da burocracia estatal $^{106}$.

Os processos de consolidação da economia capitalista e de modernização conservadora da sociedade produzem significantes mudanças técnicas e burocráticas no modo de atuação estatal do governo Getúlio Vargas. A Constituição de 1934 é inspirada na Constituição de Weimar, com a inclusão de uma ordem econômico-social e a estruturação de um federalismo cooperativo ${ }^{107}$. Estabelece o modelo do Estado-providência, “[...] assente na intervenção do estado econômico, na redistribuição da riqueza e do rendimento, na regulamentação das relações sociais, no reconhecimento de direitos econômicos e sociais aos trabalhadores, na implantação de sistemas públicos de segurança social”108.

O Estado estruturado nesse período fundamenta-se no “[...] dirigismo estatal e progressismo burguês" ${ }^{109}$, ao buscar um equilíbrio entre as classes, com forte mediação de conflitos entre as classes dominantes e entre as classes dominantes e de trabalhadores ${ }^{110}$; passa a ser tido como o "cérebro da nação" investimentos públicos e tem por fim a criação do mercado consumidor por meio da combinação entre desenvolvimento da indústria, ensino fundamental gratuito e leigo e ensino técnico profissional, assim como o abundante oferecimento de créditos públicos ${ }^{112}$. Pode-se vislumbrar uma decisão de investimento público um pouco menos ligada ao

\footnotetext{
${ }^{106}$ Cf. CARVALHO, José Murilo de. op.cit., p. 108-109; p. 120-121; p. 125-127, passim.

107 Cf. BERCOVICI, Gilberto. Constituição econômica e Constituição dirigente. In: BONAVIDES, Paulo; LIMA, Francisco Gérson Marques de; BEDÊ, Fayga Silveira. Constituição e Democracia - estudos em homenagem ao Prof. J.J. Gomes Canotilho. São Paulo: Malheiros, p. 219-448, 2006, p. 225-226.

${ }^{108}$ NUNES, Antonio José Avelãs. Uma introdução à economia política. São Paulo: Quartier Latin, 2007, p.589.

${ }^{109}$ BOSI, Alfredo. A Arqueologia do Estado-Providência: sobre um enxerto de ideias de longa-duração. In:

Dialética da colonização. São Paulo: Companhia das Letras, 2006, p. 293.

${ }^{110}$ BOSI, Alfredo. op. cit., p. 274; p. 288

${ }^{111}$ BOSI, Alfredo. op. cit., p. 287.

${ }^{112}$ BOSI, Alfredo. op. cit., p. 302.
} 
exclusivo atendimento dos interesses da elite e uma primeira tentativa de desenvolvimento do país.

Na modernização técnica e industrial, constrói-se a infraestrutura com hidrelétricas e aeroportos, além da estruturação de um sistema de previdência social. Porém, sob a ameaça de um plano de tomada do poder forjado pelos comunistas (Plano Cohen), Getúlio Vargas dá um golpe de Estado e outorga uma nova Constituição (1937), dando início ao Estado Novo (1937-1945), período em que começa a substituir importações pela produção interna e a estruturar uma forte indústria de base ${ }^{113}$ com a construção, por exemplo, da Companhia Siderúrgica Nacional, além de criar a Vale do Rio Doce e a Superintendência da Moeda e do Crédito (SUMOC). Promulga também a Consolidação das Leis Trabalhistas (1943), a disciplina normativa a tentar conter os conflitos de classe, garantindo aos trabalhadores direitos mínimos, para a tranquilidade dos industriais.

Eurico Gaspar Dutra (1946-1951) promulga a Constituição de 1946 e estabelece nessa Constituição "critérios de aproveitamento dos recursos minerais e de energia elétrica" ${ }^{114}$. Propõe uma série de medidas de caráter desenvolvimentista, dentre as quais o Plano SALTE (Saúde, Alimentação. Transporte e Energia). O plano visa a direcionar parte dos recursos públicos a setores prioritários, com elevação do saneamento básico, reaparelhamento de portos, financiamento de projetos rodoviários e ferroviários existentes e um forte incentivo à exploração do setor de energia elétrica. Caracterizou-se como uma grande tentativa de planejamento do desenvolvimento e da atuação do Estado para direcionamento das decisões de investimento público a setores essenciais. No entanto, como tantos outros, o plano não foi efetivo no cumprimento dos seus objetivos.

A volta de Getúlio Vargas ao poder (1951-1954) traz a criação de outro conjunto de empresas públicas e sociedades de economia mista, a compor o quadro da Administração Pública, tais como a Petrobrás e o BNDE - Banco Nacional de Desenvolvimento Econômico (atual BNDES - Banco Nacional de Desenvolvimento Econômico e Social). Essas empresas vêm delinear um quadro de decisões de investimento público que mudam

${ }^{113}$ Cf. FAUSTO, Boris. op.cit., p. 317.

${ }^{114}$ FAUSTO, Boris. op.cit., p. 342. 
ao longo da história do país. Sua atuação deve ser examinada com base na função, na efetividade e na eficiência, conforme tratadas no Capítulo 2 desta Dissertação. Diz-se isto em recordação principalmente da tomada de algumas recentes decisões de investimento público pelo BNDES, banco público de desenvolvimento a oferecer subsídios a interesses privados nos processos de privatização da década de 1990.

Juscelino Kubitschek (1956-1961) traz em seu governo uma nova política econômica de desenvolvimento, o Programa de Metas, que "abrangia 31 objetivos, distribuídos em 6 grandes grupos: energia, transportes, alimentação, indústrias de base, educação e a construção de Brasília, chamada de metassíntese" 115 . Serão "50 anos em 5". Fundamenta seu governo, portanto, no desenvolvimento de setores de energia e transporte, considerados estratégicos para industrialização e desenvolvimento nacional, com forte incentivo à indústria automobilística, à atração de indústrias e de capital estrangeiro e ao oferecimento de mão de obra abundante e barata para produção e consumo. Nesse ponto já se observa bem delineado o subdesenvolvimento, “[...] um processo particular, resultante da penetração de empresas capitalistas modernas em estruturas arcaicas" ${ }^{116}$, com um "[...] grau elevado de dependência do processo de formação do capital com respeito ao intercâmbio externo"117.

O Plano de Metas esboça uma experiência efetiva de planejamento, seguindo algumas linhas de transformação, a partir de investimentos que geram crescimento econômico $^{118}$. Sem dúvida, há de se levar em conta aqui um estabelecimento de uma política com relevantes decisões de investimento público e priorização de setores estratégicos, os quais resultam na construção de duas importantes usinas hidrelétricas: Furnas e Três Marias. Deve-se enfatizar ainda a tentativa de criação de superintendências para a diminuição da desigualdade e o desenvolvimento regional, tal qual a SUDENE Superintendência de Desenvolvimento do Nordeste.

\footnotetext{
${ }^{115}$ FAUSTO, Boris. op.cit., p. 362-363.

${ }^{116}$ FURTADO, Celso. Desenvolvimento e subdesenvolvimento. Rio de Janeiro: Contraponto, 2009, p.171.

${ }^{117}$ FURTADO, Celso. Desenvolvimento... op. cit., p.182.

118 Cf. BERCOVICI, Gilberto. O planejamento e a Constituição de 1988. In: SCAFF, Fernando. Constitucionalizando Direitos - 15 anos da Constituição Brasileira de 1988, p. 308.
} 
No que concerne à efetividade e eficiência do investimento público realizado no governo de Juscelino Kubitschek, pode-se questionar quão acertada foi a escolha de valorização da rede rodoviária em substituição à rede ferroviária, com a consequente imposição da indústria automobilística como política de substituição de importações e política de desenvolvimento industrial. Faz lembrar de Caio Prado Jr., que afirma não saber dizer se "o caminho cria o tipo social", mas que os transportes exerceram grande influência na formação do país ${ }^{119}$. A capacidade produtiva não foi efetiva para a superação de estruturas de desigualdade e de concentração de renda e, mesmo com a forte tendência de industrialização, a política do coronelismo e dos grandes latifúndios agroexportadores não deixou de marcar presença na apropriação dos recursos e dos esforços públicos pelos interesses privados.

Sobre a frustração em relação à política industrial na solução do problema da desigualdade no país, relata Celso Furtado:

\begin{abstract}
Naquela época, dávamos por certo que o desenvolvimento econômico e sua mola principal, a industrialização, eram condições necessárias para resolver os grandes problemas da sociedade brasileira: a pobreza, a concentração de renda e as desigualdades regionais. Mas demoramos a perceber que estavam longe de ser condição suficiente. Daí que a consciência de êxito que tive na fase inicial de avanço de industrialização haja sido substituída por sentimento de frustração. Seria simplificar o problema atribuir ao golpe militar de 1964 a causa principal da mudança de sentido em nossa história, que levaria a substituir a meta do desenvolvimento (prioritariamente social) pela do crescimento econômico, que é inerentemente criador de desigualdades e privilégios. Quando, já em começos dos anos 60, tomei consciência de que as forças sociais que lutavam pela industrialização não tinham suficiente percepção da gravidade do quadro social do país, e tendiam a aliar-se ao latifundismo e à direita ideológica contra o fantasma das organizações sindicais nascentes, compreendi que muitas águas ainda teriam de correr para que emergisse uma sociedade moderna no Brasil ${ }^{120}$.
\end{abstract}

Ainda que proposta uma política externa independente, Jânio Quadros (1961), em seus poucos meses de governo, não traz nada de novo a respeito do investimento público como forma de desenvolvimento. O país em crise política e forte oposição da UDN e de

${ }^{119}$ Cf. PRADO Jr., Caio. Formação... op. cit., p.245

${ }^{120}$ FURTADO, Celso. O Capitalismo global. São Paulo: Paz e Terra, 2001, p. 20. 
parte dos militares tem seu governo assumido por João Goulart (1961-1964), um governo de sistema parlamentarista por três anos, que retorna ao sistema presidencialista após o plebiscito de 1963. Em meio a uma crise política e econômica, assume como um governo reformista e propõe um Plano Trienal para “ [...] combinar o crescimento econômico, as reformas sociais e o combate à inflação; [...] um conjunto coerente de medidas, que buscavam resolver problemas de longo e de curto prazo"121. São evidentes as desigualdades econômicas, sociais e regionais e a forte concentração de renda proporcionada pela política governamental até então existente. Esse governo propõe a tomada de algumas medidas de nacionalização e limitação das remessas de lucros para o exterior, com uma tentativa, inclusive, de criação de uma Superintendência para a Reforma Agrária. Apesar dos esforços, não são igualmente efetivas e eficientes as medidas tomadas para a superação da crise e das desigualdades. O Plano trienal, “[...] o primeiro instrumento de orientação da política econômica global"122, não foi sequer aplicado.

Os militares tomam o poder e começam a governar com intensa repressão aos opositores e reforço do Poder Executivo Federal. Estabelecem, por meio de uma política monetária e fiscal absolutamente conservadora, condições para o fortalecimento de uma economia de livre iniciativa, redução da inflação e retomada do crescimento econômico ${ }^{123}$. Assume o general Castello Branco (1964-1967), que impõe um congelamento de créditos e salários, a contenção do déficit público e o aumento da arrecadação de tributos. A forte aliança do governo militar com os Estados Unidos faz com que os empréstimos externos e os investimentos diretos norte-americanos sustentem a economia. Mas essa abertura ao capital americano vem a contribuir com o agravamento das desigualdades sociais e regionais e com a fragilização da estrutura econômico-produtiva antes existente.

No governo de Castello Branco, trata-se de valorizar o crescimento econômico como meio de prosperidade nacional e progresso, criando diversas instituições a compor o quadro burocrático, tais como o Banco Central (em substituição à SUMOC), o INPS -

\footnotetext{
${ }^{121}$ FAUSTO, Boris. op.cit., p. 387.

122 BERCOVICI, Gilberto. O planejamento e a Constituição de 1988... op. cit., p. 312.

123 Cf. MACARINI, José Pedro. A política econômica do governo Costa e Silva 1967-1969. Rev. econ. contemp. [online]. v.10, n.3, p. 453-489, 2006, passim. Disponível em: http://www.scielo.br/. Acesso em: 16 fev. 2013.
} 
Instituto Nacional de Previdência Social, o BNH - Banco Nacional de Habitação, o FGTS - Fundo de Garantia por Tempo de Serviço e a SUDAM - Superintendência do Desenvolvimento da Amazônia. É proposto também um Programa de Ação Econômica do Governo - PAEG, cerne da política monetária de Castello Branco, através do qual se busca o combate à inflação e a contenção do crédito, com reforma fiscal e financeira, grande deterioração do poder de compra dos salários e forte estagnação econômica.

[...] O PAEG tratou de reduzir o déficit do setor público, contrair o crédito privado e comprimir os salários. Buscou controlar os gastos dos Estados, ao propor uma lei que proibia que eles se endividassem sem autorização federal. O reequilíbrio das finanças proibia da União foi obtido através da melhora da situação das empresas públicas, do corte do subsídio a produtos básicos como o trigo e o petróleo, que eram importados a uma taxa de câmbio mais baixa, e do aumento da arrecadação de impostos $^{124}$.

Promulga-se, em 1967, uma nova Constituição, com um regime teórico-formal de desenvolvimento. Ademais, aprova-se o Decreto-Lei 200, com a finalidade de promover uma reforma administrativa com desconcentração do exercício do poder às entidades da Administração indireta. Segundo alguns autores, este é um dos aspectos mais marcantes da Reforma Desenvolvimentista que, por intermédio da autonomia daquelas entidades, vem viabilizar a realização de grandes projetos ${ }^{125}$. Não há, como se pode deduzir, qualquer política de investimento público a fundamentar o desenvolvimento do país, o qual não se basta para a criação de estruturas burocráticas, de diversas instituições e superintendências.

O governo de Costa e Silva (1967-1969) é marcado politicamente por numerosas manifestações contrárias e pela forte repressão à oposição, com a edição do Ato Institucional n. 5, um ato de repressão de direitos e garantias e grande concessão de poderes excepcionais ao presidente. Em âmbito econômico, tem-se a regulamentação e o incentivo à Zona Franca de Manaus, a criação da Superintendência de Desenvolvimento do Centro-Oeste e a proposta do PED - Plano Estratégico de Desenvolvimento, outro plano monetário de forte combate do processo inflacionário.

\footnotetext{
${ }^{124}$ FAUSTO, Boris. op.cit., p. 402.

${ }^{125}$ BRESSER-PEREIRA, Luiz Carlos. Do Estado Patrimonial ao Gerencial. In: SACHS, Ignacy; WILHEIM, Jorge; PINHEIRO, Paulo Sérgio. Brasil: um século de transformações. São Paulo: Companhia das Letras, 2001, p. 236, passim.
} 
Não há nenhum sinal de efetividade no investimento público como elemento da política governamental de Costa e Silva. Como se observa, a inflação torna-se problema central na formulação das políticas governamentais do regime militar. Entretanto, vale ressaltar que o problema não tem uma natureza idêntica, com o desenrolar dos fatos. "A inflação brasileira era percebida como um fenômeno complexo, de múltiplas causas e, aspecto essencial, de natureza cambiante conforme o desenrolar da conjuntura" ${ }^{" 126}$.

O governo de Médici (1969-1974) se distingue pelo recrudescimento da repressão da oposição ao governo, com aumento das práticas de tortura e censura. No âmbito econômico, tem-se o famoso milagre econômico provocado pela redução da inflação e pelas elevadas taxas de crescimento econômico do produto interno bruto e da renda per capita. A prosperidade e o crescimento provocados pela aplicação da doutrina de segurança nacional, no entanto, não produzem desenvolvimento econômico; são reflexo de condições internacionais economicamente favoráveis. Tampouco se pode vislumbrar a efetividade do investimento público. É interessante verificar, por exemplo, a construção da Transamazônica (BR-230), a rodovia que ficou conhecida por "ligar o nada ao lugar nenhum".

A construção da Siderbrás (Siderúrgica Brasileira S.A.) e das hidrelétricas de Passo Real e Passo Fundo vêm na linha de um projeto de aceleração do crescimento e desenvolvimento da indústria e do mercado consumidor. Alguns planos ou programas foram estabelecidos como nova estratégia de desenvolvimento, dentre os quais I PND Plano Nacional de Desenvolvimento Econômico e Social, o Proterra - Programa de Redistribuição de Terras e Estímulo à Agroindústria do Norte e do Nordeste e o Prodoeste - Programa de Desenvolvimento do Centro-Oeste. Todavia, as metas e bases traçadas são absolutamente retóricas e de curto-prazo ${ }^{127}$, sendo fundamental fator na valorização e atração de capitais e na concentração no setor bancário.

\footnotetext{
${ }^{126}$ Cf. MACARINI, José Pedro. A política econômica do governo Costa e Silva 1967-1969, op. cit., p. 458. ${ }^{127}$ MACARINI, José Pedro. A política econômica do governo Médici: 1970-1973. Nova econ. [online]. 2005, v.15, n.3, p. 53-92, passim. Disponível em: <http://www.scielo.br/. Acesso em: 16 fev. 2013.
} 
O governo de Ernesto Geisel (1974-1979) estabelece uma mudança na política externa brasileira para um pragmatismo responsável, sendo bastante conhecido pelas alterações do Pacote de Abril (dentre as quais, as eleições indiretas para governador, o senador biônico e o aumento do mandato presidencial).

No âmbito econômico, o governo de Geisel assina com países vizinhos tratados e acordos para construção da hidrelétrica de Itaipu e do fornecimento de gás à Bolívia, além de formalizar a abertura política e promover a revogação das medidas de exceção. Esse governo tenta estabelecer diversos planos e programas, criando comissões e empresas para o desenvolvimento, tais como a Ibrasa (Investimentos Brasileiros S.A.), a Embramec (Mecânica Brasileira S.A.), a Cobasi (Companhia Brasileira de Insumos Básicos) e a Codevale (Companhia do Desenvolvimento do Vale do Jequitinhonha).

Propõe o II PND - Plano Nacional de Desenvolvimento Econômico e Social, um programa de investimentos para transformação da estrutura produtiva e fortalecimento industrial, que ignora no planejamento, no entanto, a proposta de solução para a concentração de renda e dos históricos problemas sociais ${ }^{128}$. O lançamento desse Plano traz a preocupação do governo em solucionar problemas no setor energético, incluindo, entre as soluções, as pesquisas no campo petrolífero, os programas nucleares e as hidrelétricas $(\text { Itaipu })^{129}$.

Observa-se o início de um novo período de estagnação e uma série de medidas de racionalização do consumo de derivados de petróleo. O governo de João Figueiredo (19791985) continua o processo de abertura política e aplicação da lei da anistia, para liberação dos presos políticos e recebimento dos exilados. Extingue ainda o cargo de senador biônico. No âmbito econômico, combate as altas taxas de inflação, reduz o déficit da balança de pagamentos e os investimentos de empresas estatais, além de aumentar as taxas de juros internos ${ }^{130}$.

\footnotetext{
${ }^{128}$ Cf. BERCOVICI, Gilberto. O planejamento e a Constituição de 1988... op. cit., p. 313.

${ }^{129}$ Cf. FAUSTO, Boris. op.cit., p. 422.

${ }^{130}$ Cf. FAUSTO, Boris. op.cit., p. 428.
} 
Mantém-se a ausência de efetividade do investimento público. Todo o dinheiro destinado ao Banco do Brasil para aplicação em projetos agrícolas é desviado para o mercado financeiro. Em acréscimo, o acordo com o FMI - Fundo Monetário Internacional - impõe ao país uma política monetária recessiva. A concentração de renda é evidente, nesse período, e o crescimento econômico não se traduz em desenvolvimento. O Estado passará de um modelo autoritário e burocrático a um modelo democrático gerencial. Explica-se. Na definição do Estado Brasileiro, identifica-se a passagem, respectivamente, em âmbito político e administrativo, de um Estado oligárquico e patrimonial (até 1930) para um Estado autoritário e burocrático (de 1930 a 1985) e, posteriormente, para um Estado democrático e gerencial (a partir da década de 1990) ${ }^{131}$.

O governo de José Sarney (1985-1990) aplica diversos planos de reforma monetária e combate à inflação, tais como o Plano Cruzado (1986), com Cruzado I e Cruzado II, tabelamento de preços, manipulação da taxa de câmbio, aumento de tributos e tentativa de contenção do consumo. As medidas levam ao desalinhamento setorial dos preços e à escassez de produtos, aos problemas de abastecimento e à aplicação de ágio. Cria-se o Fundo Nacional do Desenvolvimento, com a finalidade de administrar os empréstimos compulsórios sobre combustíveis e automóveis e as taxas sobre viagens ao exterior. Instala-se a Assembleia Nacional Constituinte, para discussão de uma nova Constituição que será promulgada em 1988, com um novo modelo institucional liberal e democrático.

A situação econômica do país, durante o governo de José Sarney, leva à declaração de moratória no pagamento dos juros da dívida externa e à imposição de medidas antirrecessivas e de estabilização da inflação. A instabilidade econômica opõe-se a qualquer tentativa de investimento público e de desenvolvimento. A necessidade de negociação com o FMI faz com que o governo se comprometa a padrões de superávit fiscal. Realiza-se uma nova tentativa de reforma econômica, com um novo plano econômico, o Plano Bresser (1987) ou Cruzado Novo.

${ }^{131}$ Cf. BRESSER-PEREIRA, Do Estado Patrimonial ao Gerencial, op. cit., p.222-259, passim. 
É interessante notar o uso da expressão choque econômico, para o combate das crises conjunturais. O Plano Bresser propõe o congelamento periódico de preços e salários, a flexibilização e a liberação de preços livres e competitivos, a retirada de subsídios setoriais, um novo aumento das tarifas dos serviços públicos, o adiamento de todas as obras governamentais, com o fim de contenção do déficit público, o arrocho salarial, uma grande desvalorização da moeda para incentivo das exportações e a manutenção do câmbio.

Mais um plano é proposto, o Plano Verão (1989), com a tomada de um conjunto de medidas econômicas visando ao congelamento de preços, a uma nova forma de reajuste de alugueis e salários e de remuneração das cadernetas de poupança, à criação de uma nova moeda (Cruzado Novo) e sua constante desvalorização em relação ao dólar. O grande déficit público provoca o aumento das emissões e empréstimos governamentais e um novo aumento da inflação. A tentativa de contenção do gasto público leva à imposição de medidas restritivas também quanto ao investimento público. Nesse período não se tem igualmente notícia de grandes projetos de investimento público.

José Eduardo Faria nos faz notar que

[...] os programas de estabilização que precederam o Plano Collor demonstraram a capacidade de controle do processo inflacionário por um limitado período de tempo, enquanto seus responsáveis tiveram capacidade de utilizar o instrumento jurídico à sua disposição para resistir a pressões sobre o gasto público e para manipular os efeitos anestesiantes sobre a demanda, obtidos por políticas monetárias e fiscal altamente restritivas e pelo congelamento de preços e salários ${ }^{132}$.

Todas as dificuldades apresentadas na condução da economia do país conduzem à eleição de Fernando Collor de Mello (1990-1992), com um programa de diminuição da participação do Estado nas atividades econômicas - com "a privatização de setores fundamentais da matriz industrial brasileira, como a siderurgia e a petroquímica"133

${ }^{132}$ FARIA, José Eduardo. Direito e economia na democratização brasileira. São Paulo: Malheiros, 1993, p. 87.

${ }^{133}$ FAUSTO, Boris. op.cit., p. 475. 
promessa de retomada do crescimento econômico, a reforma administrativa, a renegociação da dívida externa e o combate à inflação e à corrupção.

Propõe-se o Plano Brasil Novo (1990), que prevê uma nova moeda (Cruzeiro) e uma política de deflação com a retirada da moeda em circulação, além do confisco compulsório da poupança. Não tendo logrado resultados, propõe-se o Plano Collor (1991), que mais uma vez impõe ao país o congelamento de preços e salários. Collor sofre a cassação dos seus direitos políticos e o impeachment, em 1992, em decorrência das diversas evidências de corrupção em seu governo. Nesse panorama político-econômico, não se pode apontar qualquer medida de investimento público relevante para o desenvolvimento e a redução das desigualdades no país.

O governo de Itamar Franco (1992-1995) traz uma nova proposta de reforma econômica, por meio do Plano Real, com a mudança do padrão monetário e a instauração de um plano de estabilidade. O sucesso do Plano resulta na eleição de Fernando Henrique Cardoso (1995-1999), o presidente da esquerda moderna a defender a economia de mercado ${ }^{134}$. O Plano Real concretiza a diminuição das altas taxas de inflação e um retorno à credibilidade do governo. Ao mesmo tempo, estabelece uma grande contenção dos gastos públicos e o processo de privatização das estatais, para criação de caixa ao governo, uma forte elevação das taxas de juros, a abertura econômica com aumento das importações, que passam a pressionar os preços e prejudicar a estrutura produtiva do país, além da eliminação do tratamento privilegiado às empresas brasileiras de capital nacional.

Impera no país uma série de reformas gerenciais para melhoria da governabilidade e maior "eficiência" no gasto público. Nesse governo, realiza-se também a reestruturação e o fortalecimento do sistema financeiro nacional (PROER), que evita a "quebra" de diversos bancos nacionais e a iminente crise sistêmica.

A privatização no Brasil vem então inserida em uma política de estabilização da economia e diminuição da participação estatal. Alguns aspectos podem ser apontados para

\footnotetext{
${ }^{134}$ Cf. FAUSTO, Boris. op.cit., p. 482.
} 
justificar a privatização como parte da política econômica do país: a limitação da atuação governamental e o foco governamental em uma política direcionada ao mercado; a demonstração ao capital estrangeiro da efetiva abertura econômica e do compromisso de reduzir e conter os gastos estatais; e a ligação dessa política ao controle da inflação e ao financiamento de curto prazo das dívidas públicas ${ }^{135}$. Na decomposição setorial das privatizações, encontram-se, principalmente, os setores de telecomunicações, energia, siderurgia, petroquímica, saneamento, gás, portos, mineração, transportes e o setor financeiro $^{136}$.

O mais interessante de todo o processo de privatização no Brasil é o modo de exercício das funções desempenhadas pelo Banco Nacional de Desenvolvimento Econômico e Social - BNDES, o qual, desde seu envolvimento no Programa Nacional de Desestatização, parece ter-se encarregado da tomada de decisões de investimento público nos interesses privados. Pode-se citar, por exemplo, a participação do BNDES tanto nas privatizações quanto no financiamento das concentrações de empresas e na infraestrutura privada $^{137}$. Parece contraditório e além dos confins entre o público e o privado um Banco formado com captação de dinheiro público, para cumprir o interesse público, estar tão envolvido na coordenação e no financiamento dessas políticas. Ora, isso não parece sujeito a nenhuma interpretação que leve ao cumprimento dos objetivos e princípios dispostos na Constituição de 1988, tampouco cumpre qualquer tentativa de desenvolvimento, erradicação da pobreza, valorização do trabalho, dignidade da pessoa humana ou soberania nacional ${ }^{138}$.

${ }^{135}$ Cf. PINHEIRO, Armando Castelar; GIAMBIAGI, Fabio. Os antecedentes macroeconômicos e a estrutura da privatização no Brasil. In: A privatização no Brasil - o caso dos serviços de utilidade pública, Rio de Janeiro: BNDES-OCDE, p. 15-43, fev. 2000, p.15-16.

${ }^{136}$ Cf. PINHEIRO, Armando Castelar; GIAMBIAGI, Fabio. op. cit., p. 37.

137 Vide a publicação: BANCO NACIONAL DE DESENVOLVIMENTO ECONÔMICO E SOCIAL. BNDES: 50 anos de Desenvolvimento, set. 2002. Disponível em: www.bndes.gov.br. Acesso em: 11 fev. 2013.

${ }^{138}$ Os aspectos brevemente apontados neste parágrafo foram discutidos pela autora desta Dissertação no texto proposto para avaliação no $25^{\text {th }}$ Helsinki Summer Seminar in International Law, na análise do Estado como lugar de governança no sistema capitalista atual. O artigo está sujeito à análise, para futura publicação. YAMAJI, Crisleine B. Privatization as goal of a public development bank? Maybe is the time to revisit the boundaries between the public and the private, ago. 2012. 
Não é possível vislumbrar, nesse contexto de reforma gerencial, grande contribuição do investimento público no desenvolvimento do país. Observado um Estado sujeito a uma série de crises cíclicas por toda a década de 80 , propõe-se uma reforma do aparelho do Estado que passa a ser o Estado regulador ${ }^{139}$. De fato, os processos de privatização contribuíram para uma entrada imediata de receitas nos cofres governamentais, a fim de diminuir o montante da dívida pública, mas, ao mesmo tempo, trouxeram uma diminuição da entrada das receitas originárias, ou seja, aquelas decorrentes da exploração direta do patrimônio pelo Estado.

O segundo mandato de Fernando Henrique Cardoso (1999-2003) mantém a contenção inflacionária, com atrativas taxas de juros para os capitais privados, estímulo da poupança e aporte de créditos. Edita a Lei de Responsabilidade Fiscal (2000) para contenção dos gastos públicos (incluindo os investimentos) no nível das receitas disponíveis, lei esta declarada constitucional pelo Supremo Tribunal Federal. Inicia uma série de programas sociais com melhoria dos padrões de saúde pública e queda nas taxas de mortalidade infantil. Ao mesmo tempo, verifica-se a desvalorização da educação pública e gratuita e o acirramento dos conflitos no campo, por conta da reforma agrária.

No governo Fernando Henrique Cardoso, observa-se, portanto, um sucateamento da indústria nacional e a privatização da estrutura pública, com foco na contenção dos gastos estatais e no regime de superávit fiscal. A organização do sistema político passa a ser feita com base em uma organização político-social que ofereça credibilidade ao país, em âmbito internacional, com forte valorização de interesses jurídicos privados.

O governo de Luiz Inácio Lula da Silva (2003-2007) (2007-2012) não traz uma ruptura em relação ao governo anterior, quanto à política monetária de autonomia operacional do Banco Central, manutenção de metas de inflação e de superávit fiscal, apesar do grande aumento da dívida interna corrente, não sendo capaz de lidar com os gargalos com a infraestrutura decorrentes do crescimento econômico ${ }^{140}$. Ao mesmo tempo, busca implantar um modelo de desenvolvimento, fortalecendo a aliança com empresas

${ }^{139}$ BRESSER-PEREIRA, Luiz Carlos. Do Estado Patrimonial... op. cit., p. 251, passim.

${ }^{140}$ Cf. FAUSTO, Boris. op.cit., p. 539-541. 
privadas, aumentando a concentração do poder de algumas para formação de grandes companhias de capital brasileiro, além de trazer alguns programas estruturais para a criação de infraestrutura, como o PAC - Programa de Aceleração do Crescimento.

No âmbito social, procura implantar políticas com a unificação dos programas de transferência condicionada de renda, ou melhor, de dinheiro, o Bolsa Família, aumentando o número de beneficiados, principalmente no Nordeste do país, o que reduziu a extrema pobreza, com o fornecimento de moeda para o consumo, e aumentou a base eleitoral. Também tratou de comprar com dinheiro público uma série de terras para fins de reforma agrária, com poucos resultados na viabilização dos assentamentos e na fixação das famílias. Atendeu também às aspirações da classe média, por meio de um programa de financiamento para compra e construção de imóveis ${ }^{141}$.

Ressalta-se, nesse governo, uma forte política de crédito ao consumo, que sem dúvida movimenta a economia, mas não cria necessariamente renda. Parece pôr em destaque a iniciativa e os interesses privados, com a escolha de políticas contraditórias em relação à arrecadação e renúncia fiscal do governo federal, tais como a diminuição do IPI dos automóveis e a facilitação de sua compra, a desconsiderar políticas urbanas, de transporte e a própria capacidade de compra da população atingida pelos efeitos dessa política. É de se evidenciar, igualmente, a insistente permanência dos esquemas de corrupção (mensalão). Por sua vez, o governo de Dilma Roussef (2012-2016) segue as linhas gerais das políticas sociais e econômicas do governo anterior.

Resta questionar, observando esse panorama histórico, até que ponto o investimento público foi um meio efetivo e eficiente para o desenvolvimento da nossa ordem social ou se constituiu somente a expressão da conveniência das elites e dos grupos privados predominantes em determinado momento histórico, para a modernização e o crescimento econômico que não privilegiam a transformação social. Mesmo com as medidas sociais e assistencialistas do novo governo, quais mudanças fundamentais ocorreram nas escolhas públicas que levarão à consolidação de um novo quadro institucional?

${ }^{141}$ Cf. FAUSTO, Boris. op. cit., p. 539-541, passim. 
A atuação da Administração Pública a investir no benefício do setor privado, em políticas de valorização do sistema privado de educação, em financiamentos a privatizações e concentrações de empresas demonstra talvez uma mera variação de uma característica marcante dos nossos governos. Toda a História do Brasil, como se pode observar, é permeada por decisões de investimento público de efetividade questionável, com constantes políticas conjunturais de lutas contra processos inflacionários e crises econômicas.

Em linha da reflexão feita por Celso Furtado, observar nossa história leva ao questionamento pessimista: “[...] que é o nosso subdesenvolvimento senão o resultado de repetidos soçobros na decadência?" ${ }^{142}$. Assim, é o resultado de tentativas de investimento público para efetivar qualquer teórico modelo de desenvolvimento, no Brasil, o mito brasileiro - como bem verificou outrora o próprio autor.

O gigantismo estatal, a corrupção, o nepotismo, o clientelismo, o assistencialismo e a má aplicação de verbas públicas são todos elementos colocados ao lado do investimento público para justificar a necessidade de diminuição das despesas públicas e a imposição da reforma gerencial do Estado, que o torna eficiente em termos de atendimento de interesses privados e resultados lucrativos ao capital, estabelecendo metas numéricas de responsabilidade fiscal e deixando de lado o cumprimento de fins constitucionais.

\section{Ordem jurídica do investimento}

Foi feita a breve apresentação dos aspectos históricos e das características do Estado brasileiro. Passaremos à análise da ordem jurídica do investimento público, pela sua importância na verificação das funções para o alcance do desenvolvimento. Segue-se o ensinamento de Alberto Venancio Filho, segundo o qual o exame da natureza da previsão normativa da intervenção do Estado no Domínio Econômico “[...] não pode prescindir do

\footnotetext{
${ }^{142}$ Ao tratar do subdesenvolvimento como situação particular, faz-se referência a Celso Furtado, que entende que o subdesenvolvimento não é uma etapa do processo de formação de nossa economia capitalista, mas uma situação particular resultante da expansão de outras economias capitalistas. Cf. FURTADO, Celso. Quando o futuro chegar. In: SACHS, Ignacy; WILHEIM, Jorge; PINHEIRO, Paulo Sérgio. Brasil: um século de transformações. São Paulo: Companhia das Letras, 2001, p. 423.
} 
exame das características do Estado brasileiro e da forma pela qual está ele preparado a dar cumprimento a esta função"143.

A Constituição disciplina uma ordem que evidencia um sistema de interesses de determinada sociedade. Preconiza uma estrutura de poder a fundamentar a Administração Pública, atribuindo não só direitos, garantias e objetivos fundamentais, mas princípios a fixar a ordem social e o modo de intervenção. Prevê certos instrumentos a delinear o seu funcionamento, planos, programas, diretrizes e o próprio orçamento público, elementoschave no planejamento da atuação estatal no que concerne à aplicação dos seus recursos.

Encontra-se uma singular significação do investimento público e do seu regime jurídico para cada particular ordem social em cada momento histórico. O fato é que muitas das Constituições, por meio dos seus dispositivos, tentam prever uma atuação do Estado dentro de modelos de desenvolvimento nacional. Esses modelos, no entanto, parecem ter sido muitas vezes restritos a imperativos de progresso civilizatório, modernização e do crescimento econômico.

O desenvolvimento é um efeito almejado e o modelo para o seu alcance é estruturado, no Brasil, pela Constituição de 1988. Esta sofreu, ao longo dos anos, diversas emendas a enfraquecer a estrutura teórico-conceitual do modelo original. Pode-se dizer que o modelo de desenvolvimento é aquele estruturado pela combinação do artigo $1^{\circ}$, do artigo $3^{\circ}$ e dos capítulos a regular a ordem econômica e social, na Constituição de 1988. São dispositivos de transformação de uma realidade. Seu conteúdo exige uma prestação progressiva e dinâmica, ainda que não imediatamente concreta ${ }^{144}$.

$\mathrm{O}$ artigo $1^{\circ}$ trata, entre os fundamentos da ordem jurídica brasileira, da dignidade da pessoa humana, dos valores sociais do trabalho e da livre iniciativa. $\mathrm{O}$ artigo $3^{\circ}$ estabelece entre os objetivos a garantia do desenvolvimento nacional, de construção de uma sociedade

\footnotetext{
${ }^{143}$ VENANCIO FILHO, Alberto. op.cit., p. 35.

${ }^{144}$ Cf. BERCOVICI, Gilberto. Constituição econômica e desenvolvimento. Revista da Academia Brasileira de Direito Constitucional. In: SIMPÓSIO NACIONAL DE DIREITO CONSTITUCIONAL. Anais do V Simpósio Nacional de Direito Constitucional. Curitiba: Academia Brasileira de Direito Constitucional, p. 205-219, n.5, set. 2004, p. 213.
} 
livre, justa e solidária, de erradicação da pobreza, de redução das desigualdades sociais e de promoção de bem-estar de todos. Como salienta José Afonso da Silva,

[...] é a primeira vez que uma Constituição assinala, especificamente, objetivos do Estado brasileiro, não todos, que seria despropositado, mas os fundamentais, e, entre eles, uns que valem como prestações positivas que venham a concretizar a democracia econômica, social e cultural, a fim de efetivar na prática a dignidade da pessoa humana ${ }^{145}$.

Com efeito, as previsões constitucionais são elementos abstratos a compor a vertente do desenvolvimento social. No delineamento do modelo, toda a ordem social ganha contornos precisos, conforme a Constituição de 1988. Esses contornos e todo o sistema de tutela, fiscalização e responsabilidade devem fazer dos dispositivos constitucionais mais do que meras normas programáticas ou um mero modelo formal inatingível; deve trazer meios para efetivação de suas previsões. Contudo, tais meios precisam passar pela revisão das diretrizes de finanças públicas e pela própria revisão conceitual de alguns de seus principais elementos.

O modelo de desenvolvimento do Estado baseia-se em um sistema de redução das desigualdades por meio da estruturação de um sistema de garantias trabalhistas, previdenciárias e assistenciais, com vinculação de parcela das receitas à educação e à saúde e a possibilidade de manejar um sistema de finanças públicas com arrecadação e renúncia tributária.

Todos os artigos prescritivos para a ordem social (leia-se econômica e social) vêm a retomar esses fundamentos e objetivos. Assim, o artigo 170 da Constituição vigente dispõe que a ordem econômica se fundamenta na valorização do trabalho humano e na livre iniciativa, com a finalidade de assegurar a todos a existência digna, conforme os ditames da justiça social, a retomar os próprios fundamentos da República brasileira.

A ordem econômica rege-se, dessa forma, pelos princípios da soberania nacional, da propriedade privada e da função social da propriedade, da livre concorrência, da defesa

\footnotetext{
${ }^{145}$ SILVA. José Afonso da. op. cit., p. 106.
} 
do consumidor, da defesa do meio ambiente, da redução das desigualdades regionais e sociais, da busca do pleno emprego, do tratamento favorecido para as empresas de pequeno porte e do livre exercício de qualquer atividade econômica, independentemente de autorização de órgãos públicos, salvo nos casos previstos em lei.

Observa-se que essa Constituição disciplina um rol muito mais amplo de princípios gerais a reger a atividade econômica, ponderando os aspectos privados e os aspectos públicos. A menção à redução das desigualdades, à valorização do trabalho, à erradicação da pobreza e à promoção do bem-estar indica claramente as finalidades condutoras do modelo de desenvolvimento do Estado brasileiro. Esses elementos trazem grande contribuição ao debate do tema investimento público. De fato, esse investimento é um resultado da função que o Estado deve exercer, para atingir os princípios e objetivos constitucionais almejados.

A Constituição de 1988 é uma Constituição de viés principiológico, mas não se entende o princípio somente como um mandamento positivo determinado pela ordem jurídica. Ao tratar dos princípios fundamentais da Constituição, José Afonso da Silva explica que a palavra princípio é equívoca e apresenta, entre suas acepções, a ideia de começo, início; no entanto, segundo o autor, não é esse o sentido dado pela Constituição, mas aquele de mandamento nuclear de um sistema, em linha daquilo que defende Celso Antonio Bandeira de Mello ${ }^{146}$. Cabe talvez discordar dessa posição.

O princípio tem na Constituição a ideia de origem, início, mas não qualquer origem ou qualquer início; o princípio constitucional é também arké. E, nesse ponto, recorda-se da exposição feita por Francesco Cavalla, retomando os clássicos gregos. O próprio Direito tem origem no Princípio (arké), origem de todas as origens, fundamento de toda uma série indefinida de inícios. O Direito recebe do Princípio a estrutura a regular das relações entre os homens. E esse Princípio não é somente um mandamento constitucional, nem se reduz a um elemento particular da linguagem, a expressar uma série de fenômenos particulares, mas se trata de todo um conjunto de elementos da realidade. A ideia do Princípio decorre

${ }^{146}$ Cf. SILVA, José Afonso da. op. cit., p. 91. 
da própria possibilidade do pensar. Dessa ideia, define-se o Direito como instrumento insubstituível de busca da verdade e da liberdade, forma particular da experiência que não se confunde com um horizonte normativo ${ }^{147}$.

O raio de ação do Estado na efetivação do investimento público tem sua amplitude e seu modo de condução delineados por essa moldura normativa. O investimento público, em face das desigualdades regionais, vem a valorizar a estrutura de Estado Federal em uma ordem não uniforme e com grandes diferenças de qualidade de vida entre a população das suas regiões. Vem inserido em normas gerais financeiras e administrativas a dar suporte ao cumprimento dessas funções, estabelecendo um federalismo cooperativo, com a coordenação do planejamento nacional e a compatibilização de políticas entre a União e os entes federados, a fim de provocar o desenvolvimento regional ${ }^{148}$.

Em específico, o fundamento jurídico da ordem é expresso pelos valores vigentes, próprios de uma determinada sociedade, os quais devem ser aplicados de forma a levar à maior inclusão social possível, ou seja, a uma democracia econômica ${ }^{149}$. Esse debate sobre a expansão da democracia para a esfera econômica e a socialização da exclusiva propriedade privada dos meios de produção tem origem na doutrina alemã, instaurada após a Constituição de Weimar, a qual serviu de modelo para as outras Constituições a prever a ordem social, no cerne da sua disposição normativa. Explica Gilberto Bercovici que a diferença desse tipo de Constituição em relação às outras "[...] é o fato de que as constituições não pretendem mais receber a estrutura econômica existente, mas querem alterá-la. As Constituições positivam tarefas e políticas a serem realizadas no domínio econômico e social para atingir certos objetivos" $" 150$.

Os valores sociais vigentes emanam de uma mesma fonte, mas devem ser discriminados segundo sua projeção histórica, extremando-se alguns valores subordinantes

${ }^{147}$ Cf. CAVALLA, Francesco. All’origine del Diritto al tramonto della legge. Nápoles: Jovene, 2011, p. 1$3 ; 11-15,148-155$, passim.

${ }^{148}$ Cf. BERCOVICI, Gilberto. Desigualdades regionais, Estado e Constituição. São Paulo: Max Limonad, 2003, p.210-211; 240.

149 Cf. SALOMÃO FILHO, Calixto. Regulação e desenvolvimento. In: SALOMÃO FILHO, Calixto (Coord.). Regulação e desenvolvimento. São Paulo: Malheiros, 2002, p. 32.

${ }^{150}$ BERCOVICI, Gilberto. Constituição econômica e desenvolvimento... op. cit., p. 209. 
(valor-fim) da ordem social, que devem prevalecer sobre outros valores subordinados (valor-meio) dessa mesma ordem ${ }^{151}$. Seria o caso de considerar, por exemplo, o valor-fim de justiça social em relação ao valor-meio de eficiência, tão recorrente nas atuais discussões sobre a Administração Pública.

Não se concorda com a parte da doutrina que defende haver pouca orientação concreta à atuação dos sujeitos públicos ou privados, na ordem econômica, e uma grande disparidade entre os princípios previstos para essa ordem ${ }^{152}$. Diferentemente dessa visão, entende-se que os ditames da justiça social, o fim de assegurar a existência digna por meio da valorização do trabalho, o desenvolvimento por meio da erradicação da pobreza e a diminuição das desigualdades regionais são valores subordinantes que limitam a própria concretização do investimento público, tendo no desenvolvimento social um objetivo ainda a ser alcançado. Assim como Gilberto Bercovici, pensamos que a Constituição de 1988 prevê um modelo de ordem econômica voltada para a transformação das estruturas sociais $^{153}$.

Corrobora esse entendimento a observância do modo como vem disciplinada, nas Constituições anteriores - a Constituição de 1969 (Emenda Constitucional n.1) e 1967, a Constituição de 1946, a Constituição de 1937 e a Constituição de 1934 - ainda que restritas a uma abordagem formal e abstrata e imersas em uma série de contradições decorrentes da ordem político-social autoritária, oligárquica e elitista. Mesmo nessas Constituições, pode-se verificar o esboço de um modelo pleno de princípios e delineamentos a serem seguidos, com uma ordem de valores bem determinada, embora concretamente não apresentassem efetividade ou eficiência.

A Constituição de 1967, no seu artigo 157, e a Constituição de 1969, no seu artigo 160, indicavam a realização da justiça social como valor subordinante da ordem econômica, sendo meios para alcançá-la os princípios da liberdade de iniciativa, da

\footnotetext{
${ }^{151}$ Essa distinção é feita conforme a exposição quanto às possíveis classificações de valores apresentadas por Miguel Reale. Cf. REALE, Miguel. Filosofia do direito. Saraiva: São Paulo, 1965, p. 210.

${ }^{152}$ Cf. SALOMÃO FILHO, Calixto. op. cit., p. 40.

${ }^{153}$ BERCOVICI, Gilberto. Constituição econômica e Constituição dirigente... op.cit., p. 238.
} 
valorização do trabalho como condição da dignidade humana e do desenvolvimento econômico. É evidente que justiça social, em uma ordem ditatorial, parece um oxímoro. E não se pode sequer vislumbrar o desenvolvimento na busca exclusiva pelo crescimento econômico de curto prazo ou no combate da inflação galopante. O Estado, de natureza tecnocrata, passa a atuar de maneira a beneficiar os interesses privados nacionais e internacionais, aperfeiçoando condições de funcionamento das empresas privadas e causando grande concentração de capital ${ }^{154}$.

A Constituição de 1946 também estatuía, em seus artigos 145, 147 e 148, que a ordem econômica deveria ser organizada de acordo com o valor subordinante da justiça social, conciliando a liberdade de iniciativa com a valorização do trabalho humano. $\mathrm{O}$ trabalho era previsto como obrigação social e deveria ser assegurado, a fim de possibilitar a existência digna. $\mathrm{O}$ uso da propriedade era teoricamente condicionado ao bem-estar social. Sob a condução governamental de Eurico Gaspar Dutra, como já detalhado neste texto, realizou-se uma grande tentativa de planejamento estatal com um plano para aplicação de recursos, seja em aspectos mais sociais, em saúde e alimentação, seja em aspectos mais econômicos, como transporte e energia (Plano Salte). Todavia, importa notar que o mero planejamento não se configura e não se configurou em uma política econômica, funcionando apenas como instrumento de política governamental ${ }^{155}$.

A Constituição de 1937 disciplinava uma ordem econômica (artigos 135 e 136), cuja liberdade individual poderia ser exercida desde que se observassem os limites do bem público e da prosperidade nacional, sendo legítima a intervenção do Estado no domínio econômico (sob a forma do controle, do estímulo ou da gestão direta) somente para suprir as deficiências da iniciativa individual e coordenar os fatores da produção, com prevalência dos interesses da Nação, representados pelo Estado. Reconhecia o trabalho como dever social, garantindo a todos o direito de subsistir mediante o trabalho, meio de subsistência do indivíduo.

\footnotetext{
${ }^{154}$ Cf. BERCOVICI, Gilberto. Constituição econômica e Constituição dirigente... op. cit., p. 236-237.

155 FERRAZ Jr., Tercio Sampaio. A economia e o controle do Estado, O Estado de S. Paulo, abr. 1989, p. 50 apud GRAU, Eros Roberto. op. cit., p. 187.
} 
Para a Constituição de 1934, no seu artigo 115, a ordem econômica deveria ser organizada conforme valores subordinantes de justiça e de atendimento das necessidades da vida nacional, de modo a possibilitar a existência digna a todos, garantindo, dentro desses limites, a liberdade econômica. Era estabelecido um dever ao poder público de verificação periódica do padrão de vida nas várias regiões do país. Esta é a época do dirigismo estatal e da burocratização do Estado, com forte investimento público para o desenvolvimento da infraestrutura e de indústrias de base, além da criação de um mercado consumidor trabalhador e do oferecimento de bases para a instrução técnico-profissional e fundamental.

Retomando a análise da Constituição de 1988, a mudança na forma de dispor os princípios em comparação às Constituições anteriores pode ter trazido à doutrina mencionada a aparente impressão de pouca orientação concreta à atuação dos sujeitos na ordem econômica. Tomados os referidos valores estruturantes da ordem econômica como elementos conexos aos fundamentos da República Federativa do Brasil e aos seus objetivos, verifica-se o norte determinante dos efeitos e a função do investimento público. Obviamente, todas as alterações posteriormente feitas a possibilitar medidas de governabilidade e gerenciamento do Estado, abertura econômica, privatização e responsabilidade fiscal trouxeram um enfraquecimento no modelo de desenvolvimento antes criado pela Constituinte.

A breve exposição dos princípios e dos objetivos estruturantes da interpretação do investimento público, na ordem social brasileira, precisa ser conduzida ao tratamento do investimento público como efeito da atuação do Estado e elemento a impactar as finanças públicas. Pode-se vislumbrar esquematicamente a disciplina do investimento público em um conjunto de círculos concêntricos, nos quais os princípios e objetivos delineiam o limite exterior da moldura; a atuação do Estado, em conjunto com a liberdade de iniciativa privada, dois limites interiores que não atuam de modo subsidiário, mas são dois conjuntos que se comunicam. Por fim, os atos administrativos e os elementos estruturantes da finança pública constituem outros dois elementos interiores a esse círculo menor de atuação estatal. 
A análise do regime do investimento público leva a verificar a atribuição constitucional para sua realização, produto do agir ou da renúncia de agir. O tratamento do modelo de atuação do Estado, com a finalidade de atingir os objetivos e princípios dispostos para o funcionamento da ordem jurídica brasileira, não pode partir senão da fundamentação da própria Constituição.

A Constituição de 1988 será tomada como marco para esse exame do investimento público, no Brasil, enquanto efeito a proporcionar o desenvolvimento. Por intermédio dela, disciplina-se ao Estado brasileiro uma estrutura funcional e decisória na ordenação social e política. Trata-se de uma declaração escrita dos direitos e garantias fundamentais, a qual prevê uma ordem social e econômica, além de toda a estrutura das finanças públicas a ela conexa.

Nessa perspectiva, o quadro atual do investimento público, na ordem social brasileira, compõe-se dos princípios da ordem econômica previstos no artigo 170, das medidas de fiscalização, incentivo e planejamento previstas nos artigos 173 e 174 e dos investimentos públicos vinculados e discricionários da ordem social (por exemplo, os investimentos em saúde e educação, previstos respectivamente nos artigos 198 e 212 da Constituição). Somam-se a eles aqueles relativos à ordem jurídica das finanças públicas.

Os princípios da ordem econômica são conceitos e ideias inspirados em outras ordens jurídicas, porém, têm seu caráter peculiar no Estado brasileiro. Ressalta-se que sua defesa e sua aplicação não competem efetivamente ao Estado, mas ao governo. O Estado exerce suas funções por meio do governo, o que é fundamental para a análise da responsabilidade ou da probidade no investimento público. $\mathrm{O}$ agente responsável e probo é aquele que exerce a função pelo Estado em relação a esse investimento público. Ademais, faz pensar que a famosa crise fiscal do Estado não poderia ser outra que uma crise do governo, na gestão de suas finanças.

Toda atuação do Estado na ordem social, portanto, é atuação de governo. Sua qualidade, efetividade, eficiência e bom êxito dependem do governo a exercer o poder. 
Poder-se-ia, inclusive, questionar a atuação governamental com base na legitimidade que se abala, na medida em que se deixa de observar a função, os princípios e os objetivos preponderantes no exercício do poder. Considerando o investimento público a partir do principal sujeito que o realiza, parte-se do pressuposto de que o governo tem um status por meio do qual exercita deveres. Os direitos dos cidadãos de exigir uma prestação positiva dos governantes não são senão um reflexo desse dever.

As prestações concretas e positivas do Estado fundamentam-se no quadro institucional da atividade econômica ${ }^{156}$, a revelar novas funções do Estado dirigente em substituição à atuação limitada à ordem, segurança e paz, tão caras ao antigo Estado gendarme $^{157}$. Entretanto, esse Estado não é senão aquele delineado por um novo tipo de Constituição, a Constituição dirigente, cujo sentido e objetivo é " [...] dar força e substrato jurídico para a mudança social. A Constituição dirigente é um programa de ação para a alteração da sociedade" 158 .

Quanto à atribuição constitucional da iniciativa do investimento (pública ou privada), vale observar a divergência doutrinária sobre a matéria. Na visão de Geraldo Vidigal, o regime jurídico constitucional desvela um dualismo de iniciativa, regime sob o qual se distribuem as responsabilidades e os riscos da atividade econômica ${ }^{159}$. Outro a defender a dualidade de iniciativa é Giorgio Oppo, o qual salienta que, em um novo quadro de valorização da ordem social em detrimento de uma ordem meramente econômica, não há uma prioridade no que tange à ação pública, mas uma iniciativa pública pressuposta, devendo se atentar para o problema entre a relação das duas iniciativas ${ }^{160}$.

Luís Cabral de Moncada não apenas trata de uma iniciativa econômica pública, mas a qualifica como princípio de livre iniciativa pública e defende que, na vigente Constituição portuguesa, inexistem obstáculos para o exercício das competências públicas

156 Cf. VIDIGAL, Geraldo de Camargo. Teoria geral do direito econômico. São Paulo: Revista dos Tribunais, 1977, p. 165 e 166.

157 VIDIGAL, Geraldo de Camargo. Fundamentos... op.cit., p. 143-144.

${ }^{158}$ BERCOVICI, Gilberto. Constituição econômica e desenvolvimento... op. cit., p. 211.

${ }^{159}$ Cf. VIDIGAL, Geraldo de Camargo. Teoria geral..., op. cit., p. 100.

${ }^{160}$ Cf. OPPO, Giorgio. Diritto dell’impresa - scritti giuridici I, Pádua: CEDAM, 1992, p. 22, passim. 
em matéria de intervenção estatal na economia ${ }^{161}$. Segundo Natalino Irti, iniciativa privada é a esfera de ação protegida contra o Estado $^{162}$, mas este não faz expressa menção à existência de uma iniciativa pública.

Deve-se levar em conta, por outro lado, a posição dos que entendem que não há uma dupla iniciativa ou uma iniciativa pública, tal como José Tadeu De Chiara ${ }^{163}$. Para ele, a iniciativa pressuporia uma disponibilidade de interesses. A Constituição estabelece a própria delimitação da atuação estatal com a determinação do exercício do dever e do cumprimento da função, sem permitir iniciativa pública no dever de investir. Ao observar a doutrina sobre a iniciativa econômica, observa-se o enfoque na liberdade de atuar dentro da economia de mercado.

Na Constituição de 1988, fez-se uma clara opção por uma ordem social capitalista pautada em princípios da livre iniciativa, com excepcional exploração direta da atividade econômica pelo Estado. Entretanto, excepcional não quer dizer subsidiária: a excepcionalidade da atuação do Estado não significa uma proibição ao Estado, na sua esfera de atuação. Dessa maneira, devem ser observados os critérios constitucionais - tais como o relevante interesse coletivo e os imperativos de segurança nacional - os quais podem ser preponderantes inclusive sobre a liberdade de iniciativa privada.

Com base em um regime capitalista de produção, a Constituição deixa o investimento predominantemente à iniciativa do setor privado, nacional ou estrangeiro, como mencionado neste trabalho. Apesar de disciplinar os investimentos estrangeiros tendo em vista o interesse nacional, nos termos do artigo 172 da Constituição vigente, não os hostiliza; fixa preceitos para uma regulamentação de controle destes investimentos ${ }^{164}$. Pode-se enfatizar, de qualquer forma, que, após as alterações constitucionais a proporcionar maior abertura econômica, a base no interesse nacional deixou de ser

${ }^{161}$ Cf. MONCADA, Luís Cabral de. Direito Econômico. Coimbra: Coimbra Editora, 2000, p. 172-174, passim.

${ }_{162}$ Cf. IRTI, Natalino. L'ordine giuridico del mercato. Roma-Bari: Laterza, 2001, p. 93.

${ }^{163}$ Cf. DE CHIARA, José Tadeu. Aulas... op.cit.

${ }^{164}$ Cf. GRAU, Eros Roberto. A ordem econômica na Constituição de 1988. São Paulo: Malheiros, 2006, p. 196. 
substancial e passou a assumir um critério meramente formal, tal como o mero registro da sociedade perante a Junta Comercial.

Eros Roberto Grau divide a atuação do Estado em atuação no domínio econômico e atuação sobre o domínio econômico. Naquele, o Estado assumiria a posição de agente direto no exercício da atividade econômica, participando diretamente na atividade (por exemplo, o monopólio); neste, o Estado assumiria a posição de regulador de outro agente ou da própria atividade, induzindo ou dirigindo sua atuação e desenvolvimento ${ }^{165}$.

A direção é forma de atuação do Estado sobre o domínio econômico, devendo ocorrer com ações estatais de planejamento, incentivo, fiscalização, coordenação e promoção, todas ligadas ao efeito investimento público, sendo determinante para o setor público e indicativo para o setor privado.

A atuação governamental quanto ao investimento público pode se fundamentar na distribuição, na indução sob a forma de incentivo (efeito decorrente da renúncia fiscal), na intervenção direta ou na atuação por meio do planejamento ou direção da atividade econômica ${ }^{166}$. Tais formas guiam-se pela necessária produção do efeito desenvolvimento e do efeito bem-estar social e se concretizam por meio de instrumentos de orientação, estímulos fiscais, fontes privilegiadas de créditos ou taxas favorecidas de juros ${ }^{167}$.

A produção do efeito investimento público, pela atuação direta, observa previsões do artigo 173 da Constituição Federal. O Estado (leia-se governo) só pode explorar diretamente a atividade econômica, quando necessário aos imperativos da segurança nacional ou ao relevante interesse coletivo. Os critérios e limites deste dever são previstos expressamente em lei. Também a atuação normativa e regulamentadora decorre do exercício de poderes estatais específicos, em conformidade com previsões para o cumprimento das funções delineadas pelo artigo 174 da Constituição Federal.

${ }^{165}$ Cf. GRAU, Eros Roberto. op. cit., p. 93-94.

${ }^{166}$ Cf. GRAU, Eros Roberto. op. cit., p. 93-94; VIDIGAL, Geraldo de Camargo. Teoria geral... op. cit., p. 100-102.

${ }^{167}$ Cf. VIDIGAL, Geraldo de Camargo. Teoria geral... op. cit., p. 159-160. 
Na verificação do cumprimento das disposições relativas ao investimento público, deve-se averiguar a atuação do governo, como já mencionado, e sua responsabilização em face de sua atuação. Deve-se notar, portanto, a tutela da responsabilidade de membros do Poder Executivo. O dever coloca-se em primeiro plano em relação ao direito. É o dever jurídico aquele de observar estritamente a conduta prescrita na norma. Ao infringir esse dever, pratica-se um ilícito e se gera a responsabilidade e a necessária reparação do dano.

É preciso haver, portanto, uma efetiva responsabilização dos chefes do Poder Executivo quanto à sua atuação por meio do investimento público. São previstas na ordem jurídica brasileira a responsabilidade do Presidente da República, do Governador e do Prefeito em relação aos atos praticados, com a determinação da responsabilização pela execução e sua omissão no seu atuar, podendo-se tratar, inclusive, de crime de responsabilidade (de acordo com o artigo 85 da Constituição Federal vigente, da Lei 1.079/1950 e do Decreto-lei 201/1957). Esse conjunto normativo poderia ser mais efetivo na realização do investimento público para concretização de direitos e garantias constitucionais.

Analisar o investimento público enquanto produto da atuação do Estado leva ainda ao seu tratamento enquanto elemento da finança pública, inserido na disciplina tributária e financeira. Com efeito, os instrumentos de finanças públicas não podem ser reduzidos a si mesmos, como parece ter acontecido com as reformas neoliberais, com uma efetividade desvinculada de qualquer observância dos preceitos da ordem econômica constitucional ${ }^{168}$.

Procura-se compreender o enquadramento do investimento público em matéria de orçamento $^{169}$, em observância às limitações constitucionais e às diretrizes para a alocação dos recursos públicos disponíveis. Busca-se verificar as limitações impostas por meio da

\footnotetext{
${ }^{168}$ Cf. BERCOVICI, Gilberto; MASSONETO, Luís Fernando. A Constituição dirigente invertida: a blindagem da Constituição financeira e a agonia da Constituição econômica. Revista trimestral de direito público, p. 79-89, n. 45, 2004.

${ }^{169}$ Leva-se em consideração a ponderação de Geraldo de Camargo Vidigal do orçamento como ato de império a impor dimensões do investimento. VIDIGAL, Geraldo de Camargo. Fundamentos... op.cit., 1973, p. 265.
} 
chamada de responsabilidade fiscal e os critérios para determinação da "qualidade" do gasto público, que "blindam a Constituição dirigente" ${ }^{170}$, tornando-a uma "Constituição dirigente invertida" ${ }^{" 171}$. Ainda, restringem a concretização do modelo de desenvolvimento previsto na Constituição.

Alguns doutrinadores modernos apontam as finanças públicas como a disciplina do gerenciamento dos recursos pela Administração Pública para a satisfação das necessidades de determinada sociedade. Todavia, essa formulação torna a disciplina estritamente técnica. O fenômeno financeiro é um fenômeno complexo; é um poder muito imbricado no poder político. Assim, resta conciliar essa busca pela efetividade e eficiência no respeito aos princípios que expressam esse projeto político ${ }^{172}$, mas o que se tem percebido é a tensão entre duas ordens, a econômica e a financeira ${ }^{173}$, as quais deveriam concorrer para a observância dos fins e dos objetivos constitucionais.

Soma-se a isso uma grande discussão a respeito da efetividade dos investimentos públicos para concretização dos direitos sociais. No atendimento dos direitos sociais individuais, notam-se as limitações orçamentárias e a chamada reserva do possível. A expressão foi consagrada pelo Tribunal Constitucional Alemão, no sentido de reconhecer uma limitação fática do orçamento, o qual deve ser usado tendo em vista uma harmonização econômica ampla dos direitos sociais do indivíduo em relação à coletividade ${ }^{174}$.

Nas finanças públicas, há um manejo de receitas (entradas de recursos e bens aos cofres públicos) e despesas (dispêndios necessários à manutenção do Estado). As receitas são basicamente compostas pela arrecadação tributária que devem se justificar no cumprimento dos deveres constitucionalmente previstos. No entanto, a predominância de

\footnotetext{
${ }^{170}$ Cf. BERCOVICI, Gilberto; MASSONETO, Luís Fernando. op. cit., p. 87.

${ }^{171} \mathrm{Cf}$. Ibidem.

172 Cf. BOUVIER, Michel; ESCLASSAN, Marie-Christine; LASSALE, Jean-Pierre. Finances Publiques, Paris: L.G.D.J, 2008, p. 25.

${ }^{173}$ Cf. BERCOVICI, Gilberto; MASSONETO, Luís Fernando. op. cit., p. 79-80.

174 Cf. SCAFF, Fernando. A efetivação dos direitos sociais no Brasil - garantias constitucionais de financiamento e judicialização. In: SCAFF, Fernando; ROMBOLI, Roberto; MIGUEL, Revenga (Coord.). A eficácia dos direitos sociais. São Paulo: Quartier Latin, p. 22-42, 2010, p. 26.
} 
uma interpretação da eficiência como conceito econômico e quantitativo que resulta na estrita manutenção do superávit fiscal não parece efetivar o cumprimento das finalidades do Estado brasileiro. Parece retomar a natureza instrumental e neutra das finanças públicas, característica do período anterior à Segunda Guerra ${ }^{175}$.

$\mathrm{Na}$ verdade,o tratamento constitucional do investimento público enquanto elemento das finanças públicas brasileiras deve ser observado conforme os dispositivos do Título VI da Constituição vigente, que trata da tributação e do orçamento. Regula-se o investimento público enquanto efeito sobre despesas e receitas, pautado em princípios gerais financeiros e tributários constitucionalmente disciplinados. Dispõe o artigo 145 que os governos da União, dos Estados e dos Municípios poderão instituir impostos, taxas para utilização do poder de polícia ou pelo emprego de serviços públicos prestados ao contribuinte ou postos a sua disposição e a contribuição de melhoria, decorrente de obras públicas. Pode-se vislumbrar, no investimento público, a decorrência desse produto financeiro.

Em termos concretos, a competência para a produção desse efeito investimento público vem prevista no quadro normativo constitucional e, ainda, em lei complementar. Conforme o artigo 146 da Constituição de 1988, a lei complementar deve tratar não só dos conflitos de competência em matéria tributária, mas regular as limitações constitucionais do poder de tributar e estabelecer as normas gerais da matéria, incluindo o tratamento favorecido para as microempresas e para as empresas de pequeno porte e os regimes especiais ou simplificados de tributação, os quais podem se configurar como meio de investimento público, se considerados os efeitos desse tratamento diferenciado na atuação dessas empresas e nas receitas e despesas públicas orçamentárias. Em acréscimo, mediante lei complementar, poderão ser instituídos empréstimos compulsórios, vinculados às despesas que os fundamentam, considerados os investimentos públicos de caráter urgente e de relevante interesse nacional. Por fim, dispõe o artigo 149 da Constituição vigente que a União tem ainda a competência de instituir contribuições sociais, de intervenção no domínio econômico e de interesse das categorias profissionais ou econômicas, como instrumento de sua atuação nas respectivas áreas.

${ }^{175}$ Cf. BERCOVICI, Gilberto; MASSONETO, Luís Fernando. op. cit., p. 80. 
A Administração Pública deve observar uma série de limitações para o exercício do poder de tributar, do qual decorrerá o investimento público enquanto efeito do agir ou da renúncia de agir. Os princípios já foram brevemente apresentados no item 1.1 desse trabalho. Conforme o artigo 150 da Constituição, é vedado exigir ou aumentar tributo sem lei que o estabeleça; instituir tratamento desigual entre contribuintes que se encontrem em situação equivalente; cobrar tributos em relação a fatos geradores anteriormente à vigência da lei que os houver instituído ou aumentado, ou no mesmo exercício financeiro em que haja sido publicada a lei que os instituiu ou aumentou ou, ainda, antes de noventa dias da data em que haja sido publicada a lei que os instituiu ou aumentou. Também não se pode utilizar o tributo com efeito de confisco.

Algumas exceções a essas limitações são permitidas constitucionalmente e empregadas para a atuação estatal, como, por exemplo, a permissão dos impostos sobre importação de produtos estrangeiros, impostos sobre exportação de produtos nacionais ou nacionalizados para o exterior, impostos sobre produtos industrializados e impostos sobre operações de crédito, câmbio e seguro, ou relativas a títulos ou valores mobiliários. Da mesma forma, os impostos sobre a propriedade territorial rural são fixados de modo a não incidir sobre pequenas glebas rurais, quando o proprietário não possua outro imóvel.

Importa lembrar que, em matéria de investimento público, conforme artigo $150, \S 6^{\circ}$ da Constituição vigente, qualquer subsídio ou isenção ou redução de base de cálculo ou concessão de crédito presumido ou anistia ou remissão só poderão ser concedidos mediante lei específica - federal, estadual ou municipal - que regule exclusivamente a matéria ou o correspondente tributo ou contribuição.

A própria Constituição (artigo 151) admite a concessão de incentivos fiscais destinados a promover o equilíbrio do desenvolvimento socioeconômico entre as diferentes regiões do país, através de uma instituição tributária não uniforme em todo o território nacional ou que implique distinção ou preferência quanto a um Estado ou Município em detrimento de outro. Também na repartição de receitas tributárias pode a União eleger 
critérios de rateio diferenciados dos fundos de participação dos Estados e dos Municípios, objetivando promover o equilíbrio socioeconômico entre eles. Estes podem ser usados como meio efetivo para o desenvolvimento e a redução das desigualdades regionais.

As normas gerais da matéria do investimento público, elemento das finanças públicas, vêm disciplinadas em lei complementar que dispõe sobre a dívida pública externa e interna, incluídas entidades da Administração indireta, e a emissão e resgate de títulos da dívida pública, nos termos do artigo 163 da Constituição.

A política monetária (emissão de papel moeda, compra e venda de títulos públicos e a manipulação da disponibilidade de caixa dos entes da Administração Pública), competência da União, geralmente restrita à política conjuntural, não pode ser um elemento a caracterizar o investimento público. Aliás, grande parte da não efetividade do investimento público, no Brasil, esteve ligada à desastrosa gestão da política monetária, dominada sempre por medidas tentativas de contenção do incontrolável e imprevisível processo inflacionário, a prejudicar as políticas de desenvolvimento no país.

Retoma-se o olhar sobre o investimento público como produto da atuação governamental e assim se verifica que são as leis de iniciativa do Executivo a estabelecer, nos termos do artigo 165 da Constituição, o plano plurianual, as diretrizes orçamentárias e os orçamentos anuais. A alocação do investimento público é vista especialmente nessa relação entre diretrizes orçamentárias, planos plurianuais e orçamentos anuais, possibilitando a análise de normas gerais de direito financeiro para elaboração e controle dos orçamentos e balanços da União, dos Estados, dos Municípios e do Distrito Federal.

Nesse sentido, o modelo de finanças públicas previsto na Constituição de 1988 já vem estruturado a fim de buscar maior controle e transparência em relação às despesas governamentais, com maior participação do poder legislativo na aprovação das peças orçamentárias ${ }^{176}$. A reforma gerencial feita posteriormente vem trazer ainda mais restrições à capacidade de atuação governamental e ao suporte instrumental das finanças públicas, no

${ }^{176}$ Cf. BERCOVICI, Gilberto; MASSONETO, Luís Fernando. op. cit., p. 82-83. 
exercício das funções estatais para atingir as finalidades constitucionais, o que leva a um descasamento das previsões da ordem financeira no que concerne à ordem econômica.

Para estudo do investimento público nas finanças públicas, é fundamental partir da análise do plano plurianual. O plano plurianual é instituído por uma lei que fixa de forma regionalizada as diretrizes, objetivos e metas da Administração Pública federal para as despesas de capital, nas quais se incluem os investimentos públicos e outras delas decorrentes, e para as relativas aos programas de duração continuada. Além disso, o plano plurianual é a peça orçamentária de base para os planos e programas nacionais, regionais e setoriais a serem elaborados pela Administração Pública. Assim, todos os projetos de investimento público cuja execução ultrapasse um exercício financeiro deverão ser previamente incluídos no plano plurianual antes de serem iniciados, sob pena de crime de responsabilidade.

A lei de diretrizes orçamentárias ordena metas e prioridades da Administração Pública federal, incluindo as despesas de capital para o exercício financeiro seguinte. É peça fundamental na elaboração da lei orçamentária anual, prevendo, inclusive, a política de aplicação das agências financeiras oficiais de fomento.

A lei orçamentária anual compreende três orçamentos que disciplinam a previsão de receita e a fixação de despesas: orçamento fiscal da Administração Pública direta e indireta, orçamento de investimento das empresas em que a União, direta ou indiretamente, detenha a maioria do capital social com direito a voto, e orçamento da seguridade social. Seu projeto deve ser acompanhado de demonstrativo regionalizado do efeito, sobre as receitas e despesas, decorrente de isenções, anistias, remissões, subsídios e benefícios de natureza financeira, tributária e creditícia, outras formas de investimento público, conforme assumido nesse trabalho (artigo $156, \S^{\circ}$ ). As peças orçamentárias devem seguir os princípios e objetivos constitucionais e ser instrumentos efetivos a regular o desenvolvimento. 
A lei complementar é meio para a disciplina do exercício financeiro e da organização do plano plurianual, da lei de diretrizes orçamentárias e da lei orçamentária anual. Fixa igualmente normas de gestão financeira e patrimonial da Administração Pública direta e indireta, bem como condições para a instituição e funcionamento de seus fundos.

O Poder Legislativo, por meio de uma Comissão Mista de Senadores e Deputados, tem também a função e o dever de examinar e emitir um parecer sobre os projetos, as contas apresentadas anualmente pelo Presidente da República e os planos e programas nacionais, regionais e setoriais previstos nessa Constituição, além de exercer o acompanhamento e a fiscalização orçamentária. Concede-se aqui um papel importante ao legislativo, na análise e fiscalização das medidas de investimento público.

A Constituição veda, por meio do seu artigo 167, dentre outros, o início de programas ou projetos não incluídos na lei orçamentária anual, a realização de despesas ou a assunção de obrigações diretas que excedam os créditos orçamentários ou adicionais, a realização de operações de créditos que excedam o montante das despesas de capital, à exceção das autorizadas mediante créditos suplementares ou especiais com finalidade precisa, aprovadas pelo Poder Legislativo por maioria absoluta, a vinculação de receita de impostos a órgão, fundo ou despesa, ressalvada a repartição do produto da arrecadação dos impostos, a destinação de recursos para as ações e serviços públicos de saúde, para manutenção e desenvolvimento do ensino e para realização de atividades da administração tributária, a utilização, sem autorização legislativa específica, de recursos do orçamento fiscal e da seguridade social para suprir necessidade ou cobrir déficit de entes da Administração Pública.

A disciplina infraconstitucional das finanças públicas vem regulada principalmente por duas normas: a Lei n. 4.320/1964 - que estabelece normas gerais de Direito Financeiro para elaboração e controle dos orçamentos e balanços da Administração Pública, e foi recepcionada pela Constituição vigente como lei complementar - e a Lei Complementar n. 101/2000 (Lei de Responsabilidade Fiscal), que disciplina normas voltadas para a gestão e 
responsabilidade fiscal, instituindo padrões de superávit fiscal e limitações bastante rígidas no que tange aos gastos públicos, incluindo os investimentos públicos.

Segundo alguns doutrinadores, a Lei de Responsabilidade Fiscal “[...] veio a sanar espaço punitivo contra o mau administrador público"177. Entende-se, na verdade, que o regime disciplinado nessa lei explicita a substituição de um sistema "[...] voltado à organização do financiamento público da economia capitalista e à promoção do bem-estar social” 178 por um “[...] complexo normativo voltado à organização financeira do processo sistêmico de acumulação" ${ }^{179}$. O mais interessante, no entanto, é o enfoque que se dá hoje ao chamado serviço da dívida. Pode-se afirmar que a Administração Pública, após as reformas gerenciais da década de 1990, observa não só fielmente o chamado serviço da dívida, mas às vezes parece estar a serviço da dívida.

Com efeito, a alocação dos recursos públicos na política fiscal não deve se pautar somente no retorno fiscal, resultado numérico de metas fiscais da Secretaria do Tesouro Nacional. Precisa se pautar pelo cumprimento dos fundamentos constitucionais, embora estes não tragam qualquer retorno. A composição ótima da dívida pública é aquela que espelha fundamentos constitucionais e não o fortalecimento de uma posição fiscal ${ }^{180}$, ponderação que não ignora as limitações materiais e financeiras do Estado, mas propugna pela prioridade de efetivação dos fins constitucionais.

A significação do investimento público para a ordem social deve tomar os fundamentos e os objetivos constitucionais vigentes para a ordem econômica. Dessa maneira, o investimento público está inserido no cumprimento de um dever estatal, exercício de poderes e funções, encaixando-se em uma situação particular de

\footnotetext{
177 OLIVEIRA, Régis Fernandes. Responsabilidade fiscal. São Paulo: Revista dos Tribunais, 2002, p. 17.

${ }^{178}$ BERCOVICI, Gilberto; MASSONETO, Luís Fernando. op. cit., p. 89.

179 Ibidem.

180 BRASIL. Secretaria do Tesouro Nacional. Projetos de investimento público. Disponível em: <http://www.tesouro.fazenda.gov.br/ppp/index.asp>. Acesso em: 11 jul. 2011.
} 
subdesenvolvimento $^{181}$. O desenvolvimento é o principal efeito, como se verá novamente no capítulo a seguir, a fundamentar todo o quadro de funções governamentais.

${ }^{181}$ Ao tratar do subdesenvolvimento como situação particular, faz-se referência a Celso Furtado, que entende que o subdesenvolvimento não é uma etapa do processo de formação de nossa economia capitalista, mas uma situação particular resultante da expansão de outras economias capitalistas. Cf. FURTADO, Celso. Quando o futuro chegar... op.cit., p.421-422. 


\section{CAPÍTULO 2. INVESTIMENTO PÚBLICO NO BRASIL: FUNÇÃO E PLANO DOS EFEITOS}

2.1. Função do investimento público no Brasil.

2.2. Padrões de análise do investimento público no Brasil: eficácia, eficiência e efetividade.

A apreciação da significação do investimento público já nos levou à verificação dos seus elementos constitutivos e dos seus elementos estruturais. Aquela partiu de uma análise semântica do substantivo investimento e do adjetivo público. Considerou posteriormente a natureza propriamente jurídica e os princípios a fundamentá-la. Esta levou ao exame do investimento público em contexto, ou seja, da verificação dos seus aspectos históricos e do seu regime jurídico. Feitas tais ponderações, passamos a tratar da função do investimento público e de diversas possibilidades de análise no plano dos efeitos, enquanto eficácia, efetividade e eficiência.

A considerar o âmbito de análise, a função pode ser matemática, linguística, econômica, jurídica ou social. A função será tomada genericamente, para então ser juridicamente avaliada em seus elementos e requisitos. Será então analisada especificamente em face do sistema constitucional brasileiro. Nessa tarefa, será importante também um breve exame da causa e de seu fundamento.

O Direito colhe a noção de causa, fundamento de juridicidade para inserção de determinada situação na esfera jurídica. A função e a causa são essenciais para a análise e delimitação do exercício do poder pelo sujeito de direito. Expressam a finalidade que deve ser verificada no processo de mutação entre uma situação jurídica e o seu resultado, nada mais do que um efeito jurídico.

Tendo em vista que o próprio investimento público não é mais do que um resultado, uma consequência ou efeito do agir ou da renúncia de agir, serão apresentadas diferentes premissas para a análise concreta do regime jurídico, quer dizer, os padrões da eficácia, da 
efetividade e da eficiência do investimento público. A base é a própria consideração dos efeitos jurídicos no comportamento que leva ao efeito investimento.

A eficácia típica equivalente ao investimento diz respeito à capacidade de produção do efeito pelo ato jurídico ou pela renúncia tributária, especialmente determinados pelos dispositivos constitucionais e infraconstitucionais. Não se confunde com a própria função e tampouco com a efetividade ou a eficiência. Faremos uma breve análise conceitual de cada um desses elementos.

A eficácia, a efetividade e a eficiência não são a mera potencialidade de aferição de resultados quantitativos, como parece preponderar hoje no tratamento das questões financeiras do Estado brasileiro ou na análise das questões ligadas ao investimento e ao desenvolvimento, ao redor do mundo. A apreciação de resultados numéricos indica em boa medida qualquer mudança na situação fática, mas não basta para a verificação do cumprimento das previsões valorativas e finalísticas; estes não são suficientes para a verificação do cumprimento da função na observância de objetivos e princípios constitucionais.

De fato, o resultado numérico por si só não é suficiente para a constatação da eficiência em âmbito público. A análise de medidas numéricas é somente um dos aspectos da análise. A eficiência, assim como a efetividade, é uma expressão da eficácia, sendo considerada no plano dos efeitos como o melhor resultado obtido (benefícios) conforme os elementos disponíveis (custos) para a realização do ato jurídico. A eficácia predispõe a efetividade, a qual acarreta a eficiência.

A produção potencial de efeitos caracteriza a eficácia. A produção concreta dos efeitos em âmbito real caracteriza a efetividade e, à proporção que esta seja positiva, não só a propósito de uma evolução numérica, mas quanto ao exato balanceamento dos custos e dos recursos disponíveis em relação aos resultados, com um cumprimento das funções que façam atuar as finalidades (os objetivos e os princípios constitucionais), será então eficiente. 
A eficácia, a eficiência e a efetividade, mesmo que ultrapassem o âmbito da linguagem jurídica e se verifiquem no mundo real, ganham contornos precisos na aplicação do intérprete. O jurista não pode ignorar uma análise sistemática da Constituição na observância do atuar ou da renúncia em atuar do Estado para o investimento público. Esse exame deve ser feito também com base em uma breve menção crítica às variáveis e às medidas utilizadas para verificação da "qualidade" do investimento público feito pelo governo brasileiro.

No mundo real, concreto, além da mera abstração dos conceitos jurídicos e suas formulações, a eficácia há de ser efetiva e, sendo efetiva, em princípio,há de ser eficiente na medida da concretização dos preceitos constitucionais.

\subsection{Função do investimento público no Brasil}

A análise disciplina jurídica do investimento público brasileiro deve ultrapassar a abordagem dos seus elementos constitutivos ou estruturais e deve ser verificada segundo sua função. Como bem ressalta Fabio Konder Comparato, “[...] a função que as coisas exercem na vida social é independente da sua estrutura interna" ${ }^{182}$.

A função do investimento público será tratada a partir do conceito de relação, com breve menção à causa. Breve, porque não nos deteremos nas profundas divergências dogmáticas no tratamento da causa: a causa pode ser tomada como um elemento subjetivo, um animus dos sujeitos, um elemento ligado à sua vontade; ou um elemento objetivo, a justificativa interna ou externa ao ato ${ }^{183}$, que deve estar diretamente ligada à função.

O que se entende por função? A função caracteriza-se por uma relação entre elementos, entre os quais se estabelece uma relação de dependência. Na matemática, por

${ }^{182}$ COMPARATO, Fabio Konder. Função social..., p. 73.

${ }^{183}$ Cf. RÁO, Vicente. op. cit., p. 92-93. 
exemplo, concerne à relação entre os elementos de dois conjuntos. Na linguagem corrente, pode-se recordar o uso da locução "em função de", ainda que alguns gramáticos tenham qualquer repulsa quanto a ela. Ainda, lembre-se o uso da função com o sentido de fim, de causa final, ao se tratar, por exemplo, do cumprimento da função.

No Direito, a função deve ser observada a partir de uma relação de dependência entre o fim e o resultado. Apreendido sob o aspecto jurídico, o ato tende ao fim e produz o resultado, e este não coincide exatamente com o fim, mas dele depende para sua produção. A observância da função dá-se na medida em que o resultado passa a atuar o fim, não sendo o resultado por si só suficiente para a observância da função ${ }^{184}$. A função é exercitada conforme o exercício do poder ou do dever. E, dessa forma, sua análise é fundamental para a verificação do cumprimento efetivo dos fins, qualitativa dos efeitos, dos âmbitos da eficácia, efetividade e eficiência do investimento público.

Luís Recaséns Siches faz notar que no Direito há uma finalidade funcional quanto à existência humana e às necessidades sociais, a que satisfaz mediante a observância de determinados valores (fins) presentes em determinadas realidades, em determinado momento histórico ${ }^{185}$. As funções sociais são cumpridas desde que a linguagem seja ordenada de acordo com as regras a reger seu uso ${ }^{186}$.

A causa é a razão do ato, o "escopo do negócio"187. É a função no ato objetivada. Ao assumir essa postura, tem-se na causa um fundamento do efeito. Os fins econômicos e sociais são causa a ser atuada concretamente, no desenrolar do agir ou da renúncia de agir do Estado. Todos os atos seguem um escopo e, até mesmo os atos privados, como explica Emilio Betti, não são praticados em si mesmos, somente pelo prazer de praticá-los, mas buscam atingir ao escopo prático o qual governa a circulação de bens e a prestação de serviços $^{188}$.

\footnotetext{
${ }^{184}$ Cf. CARNELUTTI, Francesco. op. cit., p. 7.

${ }^{185} \mathrm{Cf}$. SICHES, Luís Recaséns. Introducción al estudio del derecho. Cidade do México: Porrúa, p.111.

${ }^{186}$ Cf. OLIVERCRONA, Karl. op. cit., p.58.

${ }^{187}$ ALPA, Guido. Manuale di Diritto Privato. Pádua: Cedam, 2011, p. 523.

188 "Cf. BETTI, Emilio. Teoria generale del negozio giuridico. Napoli: Edizione Scientifiche Italiane, 2002, p. 171
} 
Para Emilio Betti, a causa nos negócios privados é “[...] a função econômico-social que caracteriza o negócio feito de autonomia privada (típica, neste sentido) e determina seu conteúdo mínimo necessário"189. Esse posicionamento de Betti é reconhecido como sentido objetivo da causa, como explicita Antonio Junqueira de Azevedo, mas, conforme ressalta esse autor, a função de um ser não pode ser ao mesmo tempo elemento constitutivo desse mesmo ser. A expressão função, quando aplicada à causa, seria um sinônimo da causa final ${ }^{190}$.

Tal exame da função a partir da causa propicia retomar uma concepção filosófica que ajuda a entender o porquê dessa sobrevalorização do resultado em relação ao fím, tão comum nas análises modernas. A simplificação é, na verdade, consequência da própria orientação do pensamento filosófico ocidental e da imposição da técnica sobre o valor.

Heidegger, ao questionar o que significa a técnica e o modo de pensar em uma época dominada pela tecnologia, parte de uma constatação de como se concebe essa técnica ${ }^{191}$. Tal constatação será útil para se compreender a própria interpretação da causa e da função, nos dias atuais. A técnica diz respeito à atividade do homem que emprega os meios para atingir os fins e, nessa relação entre meios e fins, põe em evidência o papel instrumental da técnica e a sua neutralidade.

Não é necessário recordar toda a influência que a técnica teve, na conformação da visão de Direito hoje predominante. De qualquer forma, pode-se sustentar que a noção de fim nos leva a encontrar a noção de causa, porque o fim, segundo a antiga doutrina aristotélica, nada mais é do que uma das quatro causas possíveis. Como bem se sabe, as quatro causas aristotélicas são a causa material, a causa formal, a causa eficiente e a causa final. Continuando a seguir o raciocínio de Heidegger, este nos faz notar como nesta época

\footnotetext{
${ }^{189}$ BETTI, Emilio. Ibidem, p. 181.

${ }^{190}$ Cf. AZEVEDO, Antonio Junqueira de. Negócio Jurídico: existência, validade e eficácia. Saraiva: São Paulo, 2010, p. 153.

${ }^{191}$ HEIDEGGER, Martin. A questão da técnica. Scientiæ Studia, São Paulo, v. 5, n. 3, p. 375-398, 2007, passim./HEIDEGGER, Martin. Die Frage Nach Der Technik. Vorträge und Aufsätze. Pfullingen: Günther Neske, 1954, p. 13-44, passim.
} 
do domínio da técnica a ideia de causa foi reduzida à ideia de causa eficiente, deixando de lado as outras três causas.

A causa eficiente é aquela que, ao efetuar alguma coisa, produz essa coisa e a coloca à disposição. Contudo, a produção dessa causa vai muito além do sentido moderno de imposição e de ordenação. Ainda assim, a causa eficiente tem sido pensada como algo imposto, no sentido de um resultado criado do nada, como se fosse reduzido à mera ação que o causa.

Heidegger bem observa, no entanto, que no pensamento de Aristóteles a causa vem nomeada com a palavra aitia, que corresponde ao fato de a causa ser responsável por algo, na medida em que cada causa é responsável pela existência de alguma coisa. Assim, o ouro (causa material), o cálice (causa formal), o sagrado (causa final) e o artesão que produz o cálice de ouro para a liturgia (causa eficiente) são todos responsáveis pela sua existência. Embora o artesão (causa eficiente) seja o mais importante, exatamente por produzir o cálice, ele somente o produz se recolher todas as outras causas que levam à produção do próprio cálice.

Ora, retomando o exame de fim e resultado, que será importante posteriormente para a análise do plano dos efeitos do investimento público, todo o questionamento sobre a causa nos obriga a considerar a técnica como um meio para atingir um fim. $\mathrm{O}$ fim é uma causa que jamais pode ser pensada somente como um modo eficiente ou como produção de resultado, ainda que haja uma proeminência da causa eficiente sobre as outras causas. A técnica, expressada no exercício da função, deve revelar o que não é presente, determinar a relação entre o que é presente (resultado) e o que não é presente (fim).

Como enfatiza Natalino Irti, relembrando o ensinamento de Emanuele Severino,

[...] a técnica elevada de meio à capacidade dos fins, não atende a qualquer regime econômico: nem mesmo à economia de mercado porque o lucro é o escopo do capitalismo, mas não o escopo da técnica. Nada impede de imaginar que a eficiência, como escopo da técnica, seja contrastada com o lucro, e que o capitalismo e a economia de mercado 
sejam destruídos, isto é, reduzidos a nada, daquilo que se considerava um meio obediente e útil ${ }^{192}$.

Sobre a eficiência, trataremos mais detalhadamente a seguir.

Ao ignorar tudo isso e toda a influência da técnica no pensamento jurídico, temos a prevalência do resultado numérico, quantitativo e mensurável sobre o fim que não é presente e não é revelado; fim que, como salienta Carnelutti, jamais coincidirá com o resultado que deve buscar concretizá-lo.

O fundamento de juridicidade do sistema e da ação humana não está, portanto, restrito à causa eficiente, a qual se retomará a seguir, mas se compõe também de causa material, causa formal e causa final. Com efeito, toda esta exposição é relevante porque, em matéria de investimento público, tem-se ignorado fins e sobrevalorizado resultados. Esquecendo-se os fins delineados pela nossa Constituição vigente, passou-se a considerar o cumprimento dos fins pelos resultados. Todavia, o investimento público é o efeito da atividade dirigida aos fins constitucionais, uma expressão da função jurídica.

Na opinião de Fabio Konder Comparato, “[...] a função jurídica pode também ser tomada, num sentido mais abstrato, como atividade dirigida a um fim e comportando, de parte do sujeito agente, um poder ou competência"193. Ela pressupõe o poder e expressa um dever, coordenando os interesses. A função jurídica, portanto, é a atribuição ou poder conferido por lei para assegurar um resultado, um efeito, uma consequência jurídica ${ }^{194}$.

Porém, caberia mais um adendo. Natalino Irti destaca que a indefinida capacidade de atingir escopos é característica da técnica, mas não há a eficácia vinculante de um escopo. É ao mesmo tempo força e fraqueza, e somente a determinação dos fins pode

\footnotetext{
192 IRTI, Natalino. Diritto della Contemporaneità. In: IRTI, Natalino. Diritto senza verità. Roma-Bari: Laterza, 2011, p. 82.

${ }^{193}$ COMPARATO, Fabio Konder. Estado, Empresa e Função Social. Revista dos Tribunais, São Paulo: Ed. Revista dos Tribunais, n. 732, ano 85, p.38-46, out. 1996, p. 41.

${ }^{194}$ Cf. IRTI, Natalino. Diritto della Contemporaneità.... op.cit., p. 82.
} 
conferir essa força que estaria dispersa na indefinida e imprevisível capacidade da técnica ${ }^{195}$.

A função pública, por conseguinte, delimita o exercício do poder e atribui o correspondente dever no atuar da Administração Pública, atribuição de poder que é feita por um sistema legal vigente e se desenvolve segundo finalidades de fundamento constitucional. O dever há de ser exercido de acordo com os limites constitucionais previstos para seu exercício, dos quais tratamos no Capítulo 1.

O investimento público, com a dimensão do significado com que ora o estudamos, é o efeito fundamental da atuação do Estado, na ordem social. Pauta-se nos objetivos e princípios constitucionais do Estado democrático de Direito que tem, dentre outros fundamentos, a dignidade da pessoa humana e a valorização do trabalho e da livre iniciativa, de sorte a visar a outro efeito primordial: o desenvolvimento.

Já foram mencionados, no capítulo anterior, os objetivos fundamentais da ordem jurídica brasileira atual. São, como previsto no artigo $3^{\circ}$ da Constituição de 1988, a construção de uma sociedade livre, justa e solidária; o desenvolvimento nacional, a erradicação da pobreza e da marginalização, assim como a redução das desigualdades sociais e regionais e a promoção do bem-estar de todos. Foram igualmente abordados os princípios gerais da atividade econômica previstos no artigo 170 da Constituição. Retomando os fundamentos da valorização do trabalho humano e da livre iniciativa, ressalta a Constituição que a ordem econômica brasileira tem por fim assegurar a todos existência digna, conforme os ditames da justiça social.

Todos os objetivos e princípios constitucionais são conceitos abertos sujeitos à interpretação, assim como o substantivo investimento e o adjetivo público, porém, delineiam as funções principais relacionadas ao investimento público, das quais se destaca o desenvolvimento.

${ }^{195}$ Cf. IRTI, Natalino. Diritto della Contemporaneità... op.cit., p. 82. 
O desenvolvimento é direito fundamental, mas também é um efeito concreto de aspecto histórico. Caio Prado Jr. enfatiza que o desenvolvimento é “[...] condição precípua para assegurar ao país e à generalidade de seu povo o conforto e o bem estar material e moral que a civilização e cultura modernas são capazes de proporcionar" ${ }^{196}$. Por seu turno, explica Gilberto Bercovici: “[...] quando não ocorre nenhuma transformação, seja social, seja no sistema produtivo, não se está diante de um processo de desenvolvimento, mas da simples modernização" ${ }^{197}$.

Com efeito, o desenvolvimento expressa uma relação de renda e de qualidade de vida da população analisada decorrente do exercício do poder conforme aos objetivos almejados e tem como objetivo a "[...] elevação das condições sociais de vida e a redução, a mínimos toleráveis, das diferenças nas oportunidades econômicas e sociais entre os habitantes de várias regiões brasileiras, não o mero crescimento do PIB ou a produtividade industrial"198. Assim, diferentemente da visão de Luiz Carlos Bresser-Pereira, não se entende o desenvolvimento como "[...] processo de transformação econômica, política e social, através do qual o crescimento do padrão de vida da população tende a tornar-se automático e autônomo" 199 .

Mais uma vez, recorre-se a Caio Prado Jr., segundo o qual

[...] o desenvolvimento que sem dúvida se há de alicerçar no crescimento econômico - pois é somente através dele que o país, dado o retardo em que se encontra, poderá alcançar os níveis e o padrão da civilização moderna -, o desenvolvimento e crescimento econômico constituem tema essencialmente histórico, e ao contrário do tratamento que lhe vem sendo dado pelos economistas, não pode ser incluído em modelos analíticos de alto nível de abstração, e deve ser tratado na base da especificidade própria e das peculiaridades de cada país ou povo a ser considerado ${ }^{200}$.

\footnotetext{
${ }^{196}$ PRADO Jr., Caio. História e desenvolvimento - a contribuição da historiografia para a teoria e prática do desenvolvimento brasileiro. São Paulo: Brasiliense, 1999, p. 15-16.

${ }^{197}$ BERCOVICI, Gilberto. Constituição econômica e desenvolvimento. op. cit., p. 215.

${ }^{198}$ Cf. BERCOVICI, Gilberto. Desigualdades regionais... op.cit., p.239.

${ }^{199}$ BRESSER-PEREIRA, Luiz Carlos. Desenvolvimento e Crise no Brasil - história, economia e política de Getúlio Vargas a Lula. São Paulo: Editora 34, 2003, p. 31.

${ }^{200}$ PRADO Jr., Caio. História e desenvolvimento... op.cit., 1999, p. 15-16.
} 
O desenvolvimento é, portanto, parte da função, na medida em que fim primordial, progressiva e paulatinamente concretizado, mas também é dever do Estado, efeito a ser produzido por meio de suas políticas que incluam o efeito investimento público.

\subsection{Padrões de análise do investimento público no Brasil: eficácia, eficiência e efetividade}

A investigação feita nesta Dissertação finaliza-se com o estudo da eficácia, efetividade e eficiência, padrões de análise para a significação do investimento público. Sua clareza conceitual é imprescindível para verificar quais são os problemas da atuação do Estado quanto ao investimento público, já que esses problemas fazem com que se mantenha uma ordem social de subdesenvolvimento e desigualdade, contribuindo para um possível entendimento quanto à aplicabilidade dos preceitos previstos para a ordem social brasileira.

A análise jurídica do investimento público enquadra-o como efeito do ato jurídico ou da renúncia na arrecadação tributária, conforme já exposto neste trabalho. Nessa qualidade, o investimento público decorre de um esquema da realidade ${ }^{201}$, da concretização de uma abstração dotada de elementos necessários à produção de efeitos jurídicos. E não se trata simplesmente do modo como o legislador disciplina as funções em relação ao investimento público: interessa observar o real no exercício do poder pelo sujeito a praticar o ato ou a se abster de praticá-lo, para que o efeito investimento público aconteça.

O investimento público é um dos fatores de eficácia da ordem social brasileira. Mas não só. Exatamente por se tratar de um efeito jurídico, deve ser analisado ainda quanto à efetividade e à eficiência. A eficácia está diretamente ligada à função, ao exercício do poder, meio adequado para alcance dos fins e dos objetivos constitucionalmente propostos. A função, de seu lado, leva à efetividade quando o potencial efeito se torna resultado. Ademais, o modo do seu exercício conduz também à verificação da eficiência.

${ }^{201}$ Conforme concepção de Francesco Carnelutti, o qual se está seguindo para a argumentação apresentada nesta Dissertação. CARNELUTTI, Francesco. op. cit., p. 229. 
Sobre essa questão, comenta Luis Recaséns Siches:

[...] não basta reconhecer tão só as necessidades que se trata de satisfazer e o critério estimativo ou de valor para fazê-lo, e, em consequência, eleger os fins ou propósitos. É necessário, além disso, saber escolher os meios adequados de realização para as finalidades estabelecidas como valiosas e como meio de satisfazer as urgências sentidas. As instituições jurídicas não trazem somente um problema de finalidade justa, mas também a questão de saber realizar eficiente e logradamente a finalidade. $\mathrm{E}$ assim acontece que ao longo da história jurídica, muitas das mudanças que vão sofrendo as instituições não significam uma substituição dos fins e sim uma retificação dos meios, para lograr mais adequada e eficazmente o mesmo propósito; porque a experiência foi mostrando que talvez os meios que trataram de se articular ao serviço da finalidade fracassaram e, então, tem de se buscar novos meios, novas estruturas institucionais para realizar com maior eficácia aquela mesma finalidade ${ }^{202}$.

O exame da produção de efeitos do investimento público permite uma análise extrínseca da estrutura negocial, de fatores não integrantes do negócio, mas essenciais à obtenção do resultado ${ }^{203}$. Os fatores de eficácia são fatores iniciais, cuja qualificação auxilia a verificar os aspectos de efetividade e eficiência.

Cumpre diferenciar, então, a eficácia, a efetividade e a eficiência. A análise jurídica do plano dos efeitos do investimento público, quanto à eficácia, efetividade e eficiência, não pode ser limitada somente pelos padrões numéricos na análise do resultado. Cada medida, ainda que numérica, deve ter como fundamento o exercício da função com base nos fins e valores constitucionais impostos.

A significação do investimento público enquanto efeito jurídico contrapõe-se ao mero fortalecimento de uma posição fiscal ou às medidas baseadas no produto interno bruto. Certamente, o numérico e o quantitativo, como já ressaltamos, podem constituir um dos aspectos a ser valorizado na análise do investimento público e uma forma de verificação de diferenças no tempo e no espaço. Não obstante, o quantitativo sem o qualitativo não é suficiente para análise do plano dos efeitos do investimento público, o

${ }^{202}$ SICHES, Luís Recaséns. op. cit., p. 78.

${ }^{203}$ Cf. AZEVEDO, Antonio Junqueira de. Negócio Jurídico... op.cit., p. 55. 
qual expressa não apenas aquilo que tem de real, ontológico, como também o que tem de valorativo, axiológico.

Os efeitos jurídicos são a mutação de uma situação jurídica, ou seja, a situação jurídica final diversa de elementos iniciais juridicamente relevantes ou de uma situação jurídica inicial. Os efeitos são descritos em previsão normativa, conforme o que esteja nela disciplinada ${ }^{204}$. A eficácia, nesse sentido, é a qualidade daquilo que é eficaz; é a capacidade de irradiação de consequências ou efeitos esperados na incidência da regra jurídica no mundo concreto, a partir de determinado momento e em determinado espaço. Consiste na própria criação do direito, sendo o alcance dos efeitos jurídicos, seus limites, sua qualidade e sua intensidade determinados pela própria regra jurídica ${ }^{205}$.

A regra jurídica delimita a qualidade esperada dos efeitos jurídicos, os fins objetivados, os resultados almejados. A mesma regra jurídica determina o limite da oponibilidade dos efeitos com respeito a terceiros e a interdependência dos efeitos projetados na esfera jurídica própria ou de terceiro ${ }^{206}$.

A eficácia predispõe o concreto do acontecer. A capacidade de produzir os resultados leva à verificação dos próprios resultados produzidos, os quais fundamentam a análise da efetividade e da eficiência, produtos do real e do concreto.

A efetividade, mais do que uma doutrina de análise constitucional, indica o acontecer dos fatos, a verdade das coisas em efeito (verità effettuale, como afirma Niccolò Machiavelli) ${ }^{207}$. Contém sua significação no elemento realmente produzido, daquilo que é verdadeiro segundo fatores predispostos nas regras jurídicas vigentes. A efetividade do corpo social está dentro dele e, segundo Santi Romano, identifica-se ao próprio direito, sendo suscetível somente de um julgamento de verificação histórica que o reconheça e o

\footnotetext{
${ }^{204}$ Cf. CARNELUTTI, Francesco. op. cit., p. 229-230, passim.

${ }^{205}$ Cf. MIRANDA, Pontes de. Tratado de Direito Privado - Parte Geral, tomo V, Rio de Janeiro: Borsoi, 1955, p. 3-5; passim.

${ }^{206}$ Cf. MIRANDA, Pontes de. op. cit., p. 71-72; passim.

${ }^{207}$ Cf. IRTI, Natalino. Il mondo e lo sguardo giuridificante. In: IRTI, Natalino. Diritto senza verità. RomaBari: Laterza, 2011, p. 52.
} 
descreva como ele é. ${ }^{208}$ Por essa razão, fez-se necessária a apresentação dos principais aspectos históricos a delinear o efeito investimento público. Na verificação dos resultados, observou-se que deixava muitas vezes de ser não só eficiente, mas também efetivo.

Na verdade, a eficiência mede a relação entre os meios empregados e os resultados auferidos. Sua consideração depende de um contexto histórico-cultural ${ }^{209}$. Trata-se do funcionamento que leva ao rendimento satisfatório conforme os fins vislumbrados. A ação, nesse caso, produz a mutação ou o resultado almejado, que se faz eficiente quando atinge um resultado positivo conforme fatores, princípios e objetivos pré-determinados. É vertente da causa (causa eficiente), como já se pôde explicar neste texto.

Eficiente vem do latim ex facere. Significa algo que se faz para além; algo que se faz por determinada razão e segundo determinado fundamento; aquilo que se expõe do que se faz. A eficiência, assim como tantos conceitos atualmente estruturantes das relações sociais, sofreu uma simplificação, ou melhor, um desvirtuamento ideológico (vide, por exemplo, os conceitos de público, dignidade, justiça social e o próprio desenvolvimento) ou uma simplificação decorrente da própria idade da técnica, a qual já nos referimos neste trabalho.

Duas eficiências costumam ser vislumbradas pelas análises econômicas: a eficiência estática e a eficiência dinâmica. A eficiência estática "[...] é traduzida pelo maior grau possível de ocupação da capacidade instalada do sistema produtivo e pelo maior nível de emprego da mão de obra"210. A eficiência dinâmica consiste em “[...] uma progressiva ampliação da própria capacidade produtiva de cada país" ${ }^{211}$. Todavia, essas definições não bastam para a análise jurídica.

\footnotetext{
${ }^{208}$ Cf. IRTI, Natalino. Il mondo e lo sguardo giuridificante. op.cit., p. 54.

${ }^{209}$ Cf. DERANI, Cristiane. Privatização e serviços públicos - as ações do Estado na produção econômica. São Paulo: Max Limonad, 2002, p. 142.

${ }^{210}$ NUSDEO, Fabio. Desenvolvimento econômico - um retrospecto e algumas perspectivas. In: SALOMÃO FILHO, Calixto (Coord.). Regulação e desenvolvimento. São Paulo: Malheiros, 2002, p. 12.

${ }^{211}$ Idem, ibidem, p. 12.
} 
Apesar de o conceito de eficiência ser comumente apresentado como um conceito econômico, a ele não se restringe. É antes de tudo um conceito linguístico e social, apreendido pelo Direito de forma mais ampla que uma mera verificação econômicoquantitativa. Neste ponto, discordamos da doutrina de José Afonso da Silva, que salienta: “[...] eficiência não é um conceito jurídico, mas econômico ${ }^{212 "}$. Pode-se afirmar que, na medida em que apreendido pelo Direito, é antes de tudo jurídico e a relação entre meios escassos para obtenção de melhores resultados, intrínseca em sua análise, é igualmente uma relação valorativa, um produto de um sistema axiológico.

Convém refletir um pouco mais sobre isso, recorrendo-se ao ensinamento de Tullio Ascarelli. Obviamente, a eficiência não é um conceito jurídico formal, mas não se pode garantir que não seja um conceito jurídico. Sua autonomia como conceito jurídico, dentro de um particular sistema normativo, deve ser tomada no uso lexical. Os seus elementos, examinados pelos juristas, podem até compreender termos comumente econômicos, conceitos empíricos e descritivos, mas devem ser considerados no que tange a determinada estrutura institucional e não coincidem com uma definição logicamente pura. Estão inseridos em uma estrutura axiológica que não pode ser desconsiderada ${ }^{213}$.

Em âmbito privado, pode-se vislumbrar a eficiência na inovação. A eficiência produtiva característica dos séculos XIX e XX passa a dar lugar, neste século, à eficiência na alocação de recursos. Tudo passa a ser feito em termos de eficiência global e de vantagens comparativas, com a ponderação dos custos e benefícios dos termos de troca. Passa-se ainda a tratar o rendimento enquanto rentabilidade econômica e não como eficiência social da produção, fundamental para a esfera pública, qual seja, a satisfação do interesse coletivo no processo produtivo e não somente no produto desse processo ${ }^{214}$.

Aliás, em âmbito público, a eficiência deveria ser avaliada conforme o Estado realiza suas funções de modo a atingir as finalidades constitucionais ${ }^{215}$. Entretanto,

\footnotetext{
${ }^{212}$ SILVA, José Afonso. op.cit., p. 671.

${ }^{213}$ Cf. ASCARELLI, Tullio. Studi... op. cit., p. 29-31, p. 55-ss., passim.

${ }^{214}$ Cf. DERANI, Cristiane. op.cit., p. 72.

${ }^{215}$ Cf. DERANI, Cristiane. op. cit., p. 142.
} 
observa-se exatamente uma mudança na consideração da eficiência, que passa a se resumir à governabilidade. A governabilidade vem a ser imposta sobre a legitimidade, levando o governo a um enfoque no desempenho econômico e no rigor e saneamento das finanças públicas, com excessiva valorização da eficiência numérica e não efetivação de direitos sociais. Dela decorre toda a reforma gerencial feita na década de 1990, em nosso país, como já abordamos, no breve delineamento histórico traçado por nós.

A esse propósito, vejamos a posição de José Eduardo Faria:

[...] historicamente, a noção de governabilidade está associada à capacidade de um governo ou de uma estrutura de poder de tomar decisões no momento oportuno, sob a forma de programas econômicos, políticas públicas e planos administrativos, e de implementá-las de modo efetivo, em face de uma crescente sobrecarga de problemas institucionais, conflitos sociais e demandas econômicas. Nesse sentido, um sistema político se torna 'ingovernável' quando não consegue mais responder a essas demandas, solucionar esses problemas e dirimir esses conflitos de maneira eficaz, mesmo expandindo seus serviços, sua estrutura burocrática e seus instrumentos de intervenção. A situação-limite de um cenário de ingovernabilidade é de uma crise fiscal ${ }^{216}$.

Estudar a eficiência do investimento público possibilita ainda a abordagem estática dos elementos que o compõem, elementos constitutivos do seu significado, ou seja, o capital aplicado e o rendimento almejado. O capital são todos os custos ou os bens disponíveis a serem aplicados no processo produtivo. O capital é a expressão do poder. Os bens não se reduzem aos meios de pagamento ou à acumulação patrimonial, mas pressupõem um complexo de relações jurídicas capazes de produzirem um referido resultado no processo produtivo.

A ponderação é feita por Joseph A. Schumpeter, ao ressaltar que o capital de uma empresa não é a aglomeração de bens que atendem a objetivos. O capital é investido em bens que servem à finalidade produtiva, ou seja, o capital proporciona ao empreendedor os meios com os quais realiza a produção ${ }^{217}$. O capitalista é dono de meios de produção e

\footnotetext{
${ }^{216}$ FARIA, José Eduardo. op. cit., p. 16.

${ }^{217}$ Cf. SCHUMPETER, Joseph A. Teoria do desenvolvimento econômico: uma pesquisa sobre lucros, capital, crédito e ciclo econômico. Trad. Laura Schlaepfer. Rio de Janeiro: Fundo de Cultura, 1961, p. 159.
} 
transforma dinheiro em capital, quando o usa para adquirir mercadorias ou trabalho, com o objetivo de vendê-los novamente para obtenção do lucro ${ }^{218}$.

A aplicação do capital advém de uma decisão do sujeito investidor sobre elementos patrimoniais para gerar rendimento. Essa aplicação pode ser feita por justaposição de interesses, por exemplo, participação societária, ou contraposição de interesses, por exemplo, concessão de um crédito.

Sob a consideração de interesse privado, a eficiência marginal do capital, associada ao complexo de taxas de juros sobre empréstimos, é aquela da qual dependerá o incentivo a investir do empresário e o volume de investimento corrente ${ }^{219}$, sendo a definição das taxas de juros básicas elementos de política governamental os quais podem afetar a realização do investimento público e do investimento privado.

O rendimento consiste nos resultados, nos benefícios auferidos, no valor excedente sobre os custos (diferença entre as receitas e as despesas) ${ }^{220}$ ou no valor excedente sobre o valor de produção resultante da soma do custo dos fatores de produção (rendimento dos fatores de produção para o empresário) e de uso dos bens ${ }^{221}$. Na ponderação entre o custo e o resultado, deve ser considerado o resultado segundo o incremento da renda ou do patrimônio.

O conceito de rendimento, quando interpretado, tem sempre sido restrito a elementos quantitativos, aferíveis matematicamente. Essa eficiência numérica, matemática, não leva em conta os efeitos sociais, não aferíveis matematicamente. A análise do investimento público tem deixado de ter em vista elementos qualitativos e valorativos, a buscar a concretização dos princípios constitucionais e a verificação dos valores estruturantes da ordem econômica, dos princípios e dos objetivos do Estado brasileiro.

\footnotetext{
${ }^{218}$ Cf. HUBERMAN, Leo. op.cit., p. 167-168.

${ }^{219}$ Cf. KEYNES, John Maynard. Teoria geral do emprego, do juro e da moeda. Trad. Manuel Resende. Lisboa: Relógio d'Água, 2010, p. 54.

${ }^{220}$ Cf. SCHUMPETER, Joseph A. op. cit., p. 173.

${ }^{221}$ Cf. KEYNES, John Maynard. op. cit., p. 50, 77 e 79, passim.
} 
Sem dúvida, o rendimento é alcançado não somente para remuneração do valor do capital ou em prol de imperativos de alocação e eficiência econômica, mas de necessidade social e interesse público ${ }^{222}$. A escolha, como se pode deduzir, não é somente uma escolha neutra e técnica. Toda esta análise da eficiência deve levar em conta os fins a serem alcançados, circunstância em que deve estar o critério basilar de análise da eficiência social do investimento público, o qual deve levar em conta mais do que a quantificação dos custos e benefícios na escolha do gasto público. A predominância do critério gasto público como valor subordinante de uma ordem econômica propicia o desvirtuamento do processo de escolha, implementação e gestão dos projetos de investimento público.

Toda esta análise é decorrente de uma crítica à teoria da escolha pública (public choice theory), que baseia seus estudos em critérios de avaliação privados e individuais, com a consideração do indivíduo e suas escolhas a pautar os critérios de política ou despesa pública. Vale-se de uma possível harmonia entre esses interesses individuais e o bem-estar social, fundamentando o governo em bases de democracia liberal e de mercado. Apresenta-se, nesses termos, a análise da ação pública pela satisfação de critérios de eficiência privados ${ }^{223}$.

Como já explicitado, a eficiência é um princípio administrativo. Trata-se de um valor-meio na atuação do Estado brasileiro, previsto constitucionalmente, por intermédio da inclusão pela Emenda n. 19, de 04 de junho de 1998. O princípio vem inserido em uma série de reformas do modo de governar o Estado, mas vem interpretado através de uma simplificação conceitual e uma deturpação ideológica.

Em acréscimo, o valor-meio eficiência deve ser sopesado com os objetivos de bemestar social, pleno emprego e desenvolvimento social. Tal proposta não pode abalar a responsabilidade fiscal do Estado ou a responsabilidade da Administração Pública em usar bem o dinheiro público, tendo em vista custos, benefícios, modo de execução dos projetos

${ }^{222}$ Cf. DERANI, Cristiane. op. cit. 73-74

${ }^{223}$ Cf. ORTINO, Sergio. La sfida della Banca d'Italia all'inizio del suo secondo centenario. In: Atti di Convegno sul tema: Despecializzazione e privatizzazione degli enti creditizi. Il ruolo della Banca d'Italia, Universidade de Salerno, Faculdade de Economia, Nápoles: Edizioni Scientifiche Italiane, p. 35-47, 13-14 out. 1995. 
e verificação dos resultados alcançados. Pelo contrário, enaltece essa responsabilidade, porque cumpre os preceitos constitucionais.

Em suma, o princípio da eficiência é um princípio geral da boa administração, um elemento a determinar a realização do ato por meio da melhor utilização do capital, a fim de se atingir o melhor rendimento funcional. Obviamente, analisar a função é relembrar o que já tratamos sobre a relação entre os resultados e os fins constitucionalmente previstos. Ainda, há de se tomar a causa eficiente como parte de uma análise mais ampla.

A boa administração envolve o gerenciamento das receitas e despesas e, conforme já mencionado, estas sofrem consequências diretas do efeito investimento público, produto do agir e da renúncia de agir do Estado. Qualquer interpretação sobre finança pública pode e deve atentar para a responsabilidade fiscal, porém, esta não se reduz à quantidade de produto arrecadado ou à quantidade de despesa reduzida. A responsabilidade é decorrência do dever, e o dever constitucional é expressamente determinado. A interpretação da eficiência, por conseguinte, quanto ao efeito investimento público, precisa levar em conta o cumprimento de princípios e objetivos no exercício das funções governamentais e observar a produção do efeito desenvolvimento. São critérios qualitativos de eficiência social aqueles princípios constitucionais a serem respeitados.

Consegue-se vislumbrar alternativas para alcance do desenvolvimento nacional por meio da efetividade e eficiência dos investimentos públicos? Superadas as limitações quantitativas, abre-se caminho para um planejamento qualitativo dos gastos públicos e para a reconsideração do investimento público como meio para o desenvolvimento e não somente um elemento a entravar o atual modelo de responsabilidade fiscal. Todavia, é importante tratar, ainda que brevemente, dos tradicionais meios de aferição da eficiência do investimento público, geralmente ligados ao critério PIB (Produto Interno Bruto). Ainda que dele se trate, ressalta-se, em linha da doutrina de Gilberto Bercovici, que o desenvolvimento não pode ser avaliado somente pela mera aferição do crescimento do PIB; leva em conta fatores sociais e políticos adicionais ${ }^{224}$.

${ }^{224}$ Cf. BERCOVICI, Gilberto. Desigualdades regionais... op. cit., p.39. 
O investimento é um elemento a compor a renda, a qual se expressa pelo Produto Interno Bruto de um país. O Produto Interno Bruto é uma medida do valor da atividade econômica, sendo equivalente às despesas realizadas em determinada economia. Compõese do valor de todos os bens e serviços produzidos em um país, em um determinado período de tempo ${ }^{225}$, e pode ser considerado na sua forma real ou nominal. O PIB real pressupõe a produção, as despesas gastas com bens e serviços a preços constantes e avalia a evolução dessa produção ao longo do tempo; o PIB nominal enfoca a produção de bens e serviços a preços correntes ${ }^{226}$.

Além do investimento, outras três variáveis compõem o PIB: o consumo, as despesas governamentais e as exportações líquidas ${ }^{227}$. A variável do PIB investimento caracteriza-se como as despesas em bens (equipamentos de capital, estoques e estruturas) que serão usados no futuro para a produção de mais bens ou serviços ${ }^{228}$. Mas esta não engloba os investimentos públicos governamentais, o que é relevante na consideração dos padrões de análise de eficiência e de responsabilidade fiscal.

Os investimentos públicos governamentais são abrangidos pela variável do PIB despesas governamentais, as quais incluem também outros tipos de despesas, como as despesas com salários do funcionalismo público ${ }^{229}$. Mas vale lembrar que o investimento não se reduz à despesa pública. Sendo efeito do agir e da renúncia de agir, pode ser também a diminuição de receita de arrecadação tributária. Assim, as receitas provêm da arrecadação de tributos ou do financiamento por meio da emissão de títulos públicos para o equilíbrio das despesas ${ }^{230}$. Não há aqui uma mera fungibilidade funcional entre o investimento público e a despesa pública. O investimento público será despesa ou receita

\footnotetext{
225 MANKIW, N. Gregory. Introdução à economia. Trad. Allan Vidigal Hastings. São Paulo: Thomson Learning, 2006, p. 505.

${ }^{226}$ Cf. MANKIW, N. Gregory. op. cit., p. 507-508.

227 O Produto Interno Bruto poderia ser assim formulado: PIB $=$ Consumo + Investimento + Despesas Governamentais + Exportações líquidas.

${ }^{228}$ Cf. MANKIW, N. Gregory. op. cit., p. 507.

${ }^{229}$ Cf. MANKIW, N. Gregory. op. cit., p. 506.

${ }^{230}$ Cf. STIGLITZ, Joseph E.; WALSH, Carol E. Introdução à macroeconomia. Trad. Maria José Cyhlar Monteiro. Rio de Janeiro: Campus, 2003, p. 387.
} 
ou somente um efeito a impactar ambas nas finanças governamentais, conforme a base de produção do mesmo enquanto efeito.

Sua inclusão no montante de manutenção do funcionamento do aparelho estatal, a ser limitado no conjunto atingido pela responsabilidade fiscal, pode levar a um prejuízo no exercício das funções, quando estas forem contrapostas a restrições de superávit fiscal e a medidas de responsabilidade fiscal quanto aos gastos governamentais. Cumpre notar que os gastos governamentais são decorrentes de um montante previamente fixado e não são obrigatoriamente proporcionais à renda.

A soma da arrecadação tributária e do financiamento por meio da emissão de títulos públicos pode ser maior ou menor que o montante efetivamente gasto pelo governo, ocasionando, respectivamente, um superávit ou um déficit orçamentário ${ }^{231}$, na proporção com o Produto Interno Bruto de um país. Observa-se, no cenário internacional, a obediência às definições e limitações sugeridas por credores internacionais, dentre os quais o Fundo Monetário Internacional (FMI).

O FMI é qualificado como intérprete acreditado na economia mundial e impõe os padrões de interpretação e o limite da definição e suas alterações, por exemplo, ajustes em períodos de alta inflação e maxidesvalorização da moeda ${ }^{232}$. O tão preocupante déficit público, segundo a definição do Fundo Monetário Internacional - FMI, engloba todos os tipos de despesas e de receitas, diretas e indiretas, das três âmbitos do governo, assim como das empresas estatais, considerando inclusive toda a correção monetária e cambial e a taxa de inflação. Essa ampla compreensão do déficit orçamentário impõe, pela limitação dos efeitos e pela responsabilidade fiscal, forte restrição na capacidade de atuação governamental, o que pode prejudicar o exercício da função em vista dos fins constitucionais, provocando significativo impacto no equilíbrio orçamentário do Estado.

${ }^{231}$ Cf. NUSDEO, Fábio. Curso de Economia. São Paulo: Revista dos Tribunais, 2010, p. 297-298. MANKIW, N. Gregory. op. cit., p. 246.

${ }^{232}$ Cf. FRAGA Neto, Armínio; RESENDE, André Lara. Déficit, dívida e ajustamento: uma nota sobre o caso brasileiro. Revista de Economia Política, v.5, n.4, p. 57-66, out./dez. 1985, p.58. 
O equilíbrio do orçamento do setor público dá-se pela igualdade entre as despesas e as receitas governamentais ${ }^{233}$. E o superávit fiscal, elemento-chave para a discussão sobre a responsabilidade fiscal, é aquele resultante de um montante de receita (arrecadação tributária e emissão de títulos) superior àquele necessário para o pagamento de todas as despesas, incluindo juros da dívida pública.

A política fiscal e as ponderações sobre a responsabilidade fiscal são pautadas por metas numéricas a determinar uma atuação política, aferidas com base na relação numérica entre o montante da dívida pública e o montante do PIB (dívida pública $\div$ PIB). Não obstante, trazê-la para o âmbito valorativo faz com que se demonstre como medida insuficiente para imposição de comportamentos no exercício das funções governamentais.

O investimento público deve ser feito de sorte a aumentar a renda que expressa um poder de compra e não resulta da mera detenção uma determinada quantidade de moeda. Enquadra-se em um conjunto de efeitos capazes de influenciar a economia, trazendo um aumento da produtividade da economia e uma geração de demanda de bens e serviços e, resultando em despesa, deve ter a qualidade de justificar a arrecadação tributária equivalente a reduzir a renda, o poder de compra e a quantidade de moeda disponível. Há um efeito multiplicador sobre o que será produzido, em âmbito privado.

No que tange à política de investimento público, observa-se que o próprio financiamento da atividade governamental e das despesas públicas pode ser feito por meio da emissão de títulos públicos com atrativas taxas de juros (a serem considerados em padrões de superávit ou déficit primário). Isso leva não só ao recolhimento da moeda disponível e a uma contenção dos padrões inflacionários, mas até mesmo a um conflito em relação ao agir e à renúncia de agir.

O governo, na produção do efeito investimento público, deve levar em conta igualmente os critérios qualitativos na definição de políticas conjunturais e de prioridades governamentais, porque as atrativas taxas de juros tanto aumentam o volume das despesas

${ }^{233}$ Cf. MANKIW, N. GREGORY. op.cit., p. 576. 
públicas, quanto desviam o capital que seria aplicado no setor produtivo pelos investidores privados $^{234}$. Ademais, aumentam a própria remuneração do crédito produtivo e do crédito ao consumo, os quais passam a prever, no mínimo, os padrões de remuneração dos títulos governamentais, para assim atrair o capital que seria direcionado à aquisição de títulos públicos. E isso se torna ainda mais prejudicial, quando o governo, de outro lado, vem a estabelecer uma política de crédito de consumo sem o devido planejamento para seu controle. Esse cenário é delével não só para o efeito investimento público, mas também para o efeito desenvolvimento, mutação jurídica almejada em termos constitucionais.

Retornando à análise da eficiência do investimento público, no Brasil, percebe-se que o padrão PIB é medida predominante no seu padrão de análise, mas, como já frisamos, não suficiente. Segundo o Instituto de Pesquisas Econômicas Aplicadas (IPEA), o investimento público é considerado eficiente conforme a relação entre sua taxa percentual e o PIB. Toma-se uma taxa de investimento anualizada (\%), uma relação dos valores nominais acumulados do investimento em relação ao PIB $^{235}$.

Quando se toma esse padrão de análise, como é possível verificar a eficácia, a efetividade e a eficiência social em relação ao cumprimento de valores axiológicos? O gráfico de taxas de investimento público pode incluir variáveis axiológicas, em suas curvas? É possível mensurar por meio dessa técnica de eficiência numérica o bom exercício da função pública? Parece que a técnica não resulta inventiva o bastante para a valoração segundo os fins e os princípios constitucionais.

E o mesmo problema se observa nas análises feitas pelo Banco Mundial e pelo Fundo Monetário Internacional. Seus relatórios continuam a ter o investimento público enquanto meio para o crescimento econômico, focando sobretudo em questões de deficiência de infraestrutura e reduzida produtividade dos fatores estruturais, tais como a burocracia e a pouca atratividade para os investimentos e financiamentos privados. É evidente que trazem igualmente um questionamento quanto à qualidade da escolha,

${ }^{234}$ Cf. STIGLITZ, Joseph E.; WALSH, Carol E. op.cit., p. 387.

${ }^{235}$ IPEA - Instituto de Pesquisas Econômicas Aplicadas. Como anda o investimento público no Brasil?, Comunicado n. 126, 29 nov. 2011. 
execução e fiscalização dos projetos de investimento que devem ser levadas em conta ${ }^{236}$, mas focam em valores numéricos quando deveriam considerar valores sociais.

Como já defendido tantas e tantas vezes, neste trabalho, a análise do investimento público deveria ter um foco mais centrado na busca de concretização dos fins e objetivos delineados pelas respectivas ordens constitucionais, que não são somente um ideal dos legisladores. Toda essa ponderação não visa a ignorar as limitações financeiras do Estado, no uso dos recursos escassos para a realização da despesa pública ou para a renúncia de receita, como já ressaltamos. Nada impede, porém, que os recursos escassos sejam considerados conforme uma aferição qualitativa do gasto a ser realizado, a fim de que este justifique legitimamente qualquer aumento da carga tributária a pesar sobre o contribuinte. O aplicar de recursos públicos deve ser qualitativo, assim como o cortar dos referidos recursos ou o fiscalizar dessa aplicação. Ou, ainda, a ponderação do montante a pagar de juros da dívida pública.

Os mesmos problemas são observáveis no que se refere a outro importante efeito constitucionalmente previsto, fundamental na definição no planejamento das políticas governamentais: o desenvolvimento. Este costuma ser mensurado por quantidades numéricas de análise, tais como a variação em relação ao Produto Interno Bruto - PIB, a um número de pessoas acima de uma determinada e hipotética linha de pobreza, a certo número de crianças que completaram o ensino fundamental, a um número de hospitais construídos. Sem dúvida, o padrão de análise numérico ajuda a avaliar algumas alterações qualitativas. Jamais se contestaria que é melhor haver cem crianças a cursar o ensino fundamental do que cinquenta. Contudo, a alteração numérica expressa outra alteração realmente substantiva e qualitativa? Há de fato um incremento de valor nesse desenvolvimento verificado numericamente? Entendemos que não. $\mathrm{O}$ aspecto quantitativo é, sem dúvida, um critério de análise. Os índices são um resultado lógico, um padrão a ser

\footnotetext{
${ }^{236}$ DABLA-NORRIS, Era; BRUMBY, Jim; KYOBE, Annette; MILLS, Zac; PAPAGEORGIOU, Chris. Investing in Public Investment: An Index of Public Investment Efficiency. IMF Working Paper, WP/11/37, Washington: Fundo Monetário Internacional, fev. 2011, passim; RAJARAM, Anand; LE, Tuan Minh; BILETSKA, Nataliya; BRUMBY, Jim. A Diagnostic Framework for Assessing Public Investment Management. Policy Research Working Paper WPS 5397, Washington: Banco Mundial, ago.2010, passim.
} 
levado em conta, mas não são suficientes para mensurar a eficiência no cumprimento da Constituição ou no bom exercício da função. 


\section{CONSIDERAÇÕES FINAIS}

Celso Furtado incentivava a atividade do pesquisador, enfatizando que caberia a este "[...] imaginação e coragem para arriscar na busca do incerto"237. A elaboração desta Dissertação de Mestrado visa à busca da incerta significação do investimento público e a uma reavaliação de sua qualidade enquanto meio efetivo e eficiente para possibilitar a superação de estruturas de subdesenvolvimento no país. Foca-se, neste caso, em seus padrões de análise, interpretados restritivamente e sem considerar os fins constitucionalmente previstos.

$\mathrm{Na}$ verdade, o incentivo para esta pesquisa nasceu da constatação de que o jurídico não pode se reduzir à apreensão do conceito econômico e ao aspecto quantitativo, na avaliação da ordem social. Se o econômico é incapaz de valorações condizentes à realidade, deve o jurídico determinar os critérios para atingir os seus fins.

A imposição de uma análise neutra, com a exclusão da análise axiológica e o enfoque estritamente numérico, faz com que as palavras da Constituição não deem realidade ao corpo de ideias por ela representadas. Historicamente, parece recrudescer o problema de desacordo entre o idealismo das constituições e a realidade nacional ${ }^{238}$.

O modelo de desenvolvimento econômico é concretizável, mas a linguagem jurídica a conformar o investimento público deve ser o produto de um exame do intérprete a tomar os justos critérios, para a consideração do fato social. Parecia inexplorado o questionamento da significação jurídica do investimento público do modo como buscamos esboçar: uma análise de elementos constitutivos, estruturais e reais.

Arriscou-se precisar uma percepção jurídica de um tema pouco abordado, contudo, fundamental para se pensar na forma de exercício do poder e no desenvolvimento do

\footnotetext{
${ }^{237}$ FURTADO, Celso. op.cit., p. 10.

${ }^{238}$ Cf. VIANNA, Oliveira. O idealismo da Constituição. Rio de Janeiro-Recife-São Paulo: Nacional, 1939, p. 81, p. 87, p.93, passim.
} 
Estado. Discutir os conceitos, a função e os diversos planos de análise do investimento público enquanto efeito, com enfoque na eficácia, efetividade e principalmente na eficiência, dá ao investimento um novo significar que parece ignorado e esquecido em suas interpretações. Assim, procurou-se focalizar toda essa problemática a partir de uma discussão de natureza teórica. Dissertar é também criticar, pôr em evidência um problema na aplicação dos critérios corriqueiramente adotados.

Propôs-se, portanto, uma análise de aspecto teórico-conceitual, baseando-se na significação do investimento público e verificando-se a semântica dos seus termos investimento e público. Passou-se a analisar seus elementos estruturais, tratando de elaborar uma análise estática, pela natureza e decisão de investimento público, e de uma análise dinâmica, a partir do regime jurídico e seus principais aspectos históricos. Buscouse ressaltar a função para entender o exercício do poder e a ligação com a causa enquanto fim. Quanto aos efeitos, foram verificados os aspectos da eficácia, da efetividade e da eficiência e, ao final, concluiu-se que os resultados hoje considerados eficientes, baseados em índices e padrões de aspectos numéricos, desconsideram os fins e objetivos constitucionalmente previstos.

O Brasil ainda está distante de observar as transformações sociais incluídas nas linhas de desenvolvimento da Constituição de 1988, porém, como se ressaltou nesta Dissertação, a superação do subdesenvolvimento é um processo dinâmico a produzir a cada instante novos efeitos. A efetividade e a eficiência não estão presentes na simples análise quantitativa, mas podem se tornar elementos fundamentais de superação de velhas estruturas, quando passarmos a considerar os conceitos de modo mais consciente e condizente com o texto constitucional.

Efetivo e eficiente será o investimento público do futuro, que virá a concretizar uma transformação social, uma concretização dos fins constitucionais. São 500 anos e já estamos cansados de observar o investimento público a atender a interesses privados, a reproduzir ordens de dominação e a manter de velhas estruturas de desigualdade. 


\section{REFERÊNCIAS}

ALLIONE, Miro. Qualche consideraizone introduttiva sui criteri di scelta degli investimenti effetuati dallo Stato. In: ALLIONE, Miro (Coord.). Le decisioni di investimento pubblico. Milão: Franco Angeli, 1971.

ALMEIDA, Napoleão Mendes de. Dicionário de questões vernáculas. São Paulo: LCTE, 1994.

ALPA, Guido. Manuale di Diritto Privato. Pádua: Cedam, 2011.

ASCARELLI, Tullio. Studi di Diritto Comparato e in Tema di Interpretazione. Milão: Giuffrè, p. 55 e ss., 1952.

Antigone e Porzia in Rivista Internazionale di Filosofia del Diritto, 1955, n. 756, agora in: Problemi giuridici, Vol. I, Milão: Giuffrè, p. 147 e ss., 1959.

ATALIBA, Geraldo. Empréstimos públicos e seu regime jurídico. São Paulo: Revista dos Tribunais, 1973.

AZEVEDO, Antonio Junqueira de. O princípio da boa-fé nos contratos. In: CONSELHO DA JUSTIÇA FEDERAL. Série Cadernos do CEJ - Centro de Estudos Judiciários, v.20, Brasília, 2002.

Saraiva: São Paulo, 2010.

Negócio Jurídico: existência, validade e eficácia.

BALEEIRO, Aliomar. Direito tributário brasileiro; atual. Misabel Abreu Machado Derzi, Rio de Janeiro: Forense, 2010.

BANCO NACIONAL DE DESENVOLVIMENTO ECONÔMICO E SOCIAL. BNDES: 50 anos de Desenvolvimento, set. 2002. Disponível em: www.bndes.gov.br. Acesso em: 11 fev. 2013.

BATTISTI, Carlo; ALESSIO, Giovanni. Dizionario etimologico italiano. Florença: Barbèra, 1952.

BERCOVICI, Gilberto. Constituição econômica e Constituição dirigente. In: BONAVIDES, Paulo; LIMA, Francisco Gérson Marques de; BEDÊ, Fayga Silveira. Constituição e Democracia - estudos em homenagem ao Prof. J. J. Gomes Canotilho. São Paulo: Malheiros, p. 219-448, 2006.

. Constituição econômica e desenvolvimento. Revista da Academia

Brasileira de Direito Constitucional. In: SIMPÓSIO NACIONAL DE DIREITO CONSTITUCIONAL. Anais do V Simpósio Nacional de Direito Constitucional. Curitiba: Academia Brasileira de Direito Constitucional, p. 205-219, n.5, set. 2004. 
Limonad, 2003.

Desigualdades regionais, Estado e Constituição. São Paulo: Max

O planejamento e a Constituição de 1988. In: SCAFF, Fernando.

Constitucionalizando Direitos - 15 anos da Constituição Brasileira de 1988.

BERCOVICI, Gilberto; MASSONETO, Luís Fernando. A Constituição dirigente invertida: a blindagem da Constituição financeira e a agonia da Constituição econômica. Revista trimestral de direito público, p. 79-89, n. 45, 2004.

BETTI, Emilio. Interpretazione della legge e degli atti giuridici - teoria generale e dogmatica. Milão: Giuffrè, 1971.

Italiane, 2002.

Teoria generale del negozio giuridico. Napoli: Edizione Scientifiche

BOBBIO, Norberto. Dalla struttura alla funzione: nuovi studi di teoria del diritto. RomaBari: Laterza, 2007.

BONAVIDES, Paulo. Do estado liberal ao estado social. Rio de Janeiro: FGV, 1972.

BOSI, Alfredo. A Arqueologia do Estado-Providência: sobre um enxerto de ideias de longa-duração. In: Dialética da colonização. São Paulo: Companhia das Letras, 2006.

BOUVIER, Michel; ESCLASSAN, Marie-Christine; LASSALE, Jean-Pierre. Finances Publiques, Paris: L.G.D.J, 2008.

BRASIL. Secretaria do Tesouro Nacional. Projetos de investimento público. Disponível em: <http://www.tesouro.fazenda.gov.br/ppp/index.asp>. Acesso em: 11 jul. 2011.

BRESSER-PEREIRA, Luiz Carlos. Desenvolvimento e Crise no Brasil - história, economia e política de Getúlio Vargas a Lula. São Paulo: Editora 34, 2003.

. Do Estado Patrimonial ao Gerencial. In: SACHS, Ignacy;

WILHEIM, Jorge; PINHEIRO, Paulo Sérgio. Brasil: um século de transformações. São Paulo: Companhia das Letras, 2001.

BUENO, Francisco Silveira. Grande dicionário etimológico-prosódico da língua portuguesa: vocábulos, expressões da língua geral e científica - sinônimos; contribuições do tupi-guarani. São Paulo: Saraiva, 1968.

CARNELUTTI, Francesco. Teoria generale del diritto. Roma: Soc. Ed. del Foro Italiano, 1951; reestampa: Camerino: Università di Camerino-Edizioni Scientifiche Italiane, 1998.

CARVAlHO, José Murilo de. Brasil 1870-1914: a força da tradição. In: Pontos e bordados: escritos de história e política. Belo Horizonte: Ed. UFMG, 2005. 
CAVALLA, Francesco. All'origine del Diritto al tramonto della legge. Nápoles: Jovene, 2011.

CHENERY, Hollis B. L'applicazione di criteri d'investimento. In: ALLIONE, Miro (Coord.). Le decisioni di investimento pubblico. Milão: Franco Angeli, 1971.

COMPARATO, Fabio Konder. Estado, Empresa e Função Social. Revista dos Tribunais. São Paulo: Ed. Revista dos Tribunais, n. 732, ano 85, p.38-46, out. 1996.

Função social da propriedade dos bens de produção.

Revista de Direito mercantil, n. 63, p. 71-79, jul./set. 1986.

CORTELAZZO Manlio; ZOLLI, Paolo. Dizionario etimologico della língua italiana. Bologna: Zanichelli, 1992.

CUNHA, Antônio Geraldo (et. al.). Dicionário etimológico Nova Fronteira da língua portuguesa. Rio de Janeiro: Nova Fronteira, 1999.

DABLA-NORRIS, Era; BRUMBY, Jim; KYOBE, Annette; MILLS, Zac; PAPAGEORGIOU, Chris. Investing in Public Investment: An Index of Public Investment Efficiency. IMF Working Paper, WP/11/37, Washington: Fundo Monetário Internacional, fev. 2011.

DAUZAT, Albert; DUBOIS, Jean; MITTERAND, Henri. Dictionnaire étymologique et historique du français. Paris: Larousse, 1993.

DE CHIARA, José Tadeu. Aulas ministradas no curso de Direito Econômico II e Direito Econômico aplicado na Faculdade de Direito da Universidade de São Paulo nos anos de 2007, 2009, 2010 e 2011. São Paulo, 2011.

Moeda e ordem jurídica. 1986. Tese (Doutorado) - Faculdade de Direito, Universidade de São Paulo, São Paulo, 1986.

DERANI, Cristiane. Privatização e serviços públicos - as ações do Estado na produção econômica. São Paulo: Max Limonad, 2002.

FARIA, José Eduardo. Direito e economia na democratização brasileira. São Paulo: Malheiros, 1993.

FAUSTO, Boris. História do Brasil. São Paulo: EDUSP, 2012.

FERNANDES, Francisco. Dicionário de sinônimos e antônimos de língua portuguesa. Porto Alegre: Globo, 1980.

FERRAZ Jr., Tercio Sampaio. A economia e o controle do Estado. O Estado de S. Paulo, abr. 1989. 
Introdução ao Estudo do Direito. São Paulo, Atlas, 2007.

FOURNERET, Pierre. Que sais-je? L'Administration Économique. Paris: Presses Universitaires de France, 1980.

FRAGA Neto, Armínio; RESENDE, André Lara. Déficit, dívida e ajustamento: uma nota sobre o caso brasileiro. Revista de Economia Política, v.5, n.4, p. 57-66, out./dez. 1985.

FRANKENBERG, Günter. Constructing legal traditions introductory remarks on the public/private-distinction as tradition. Comparative Law Review, v.2, n.1, p. 1-12, 2011.

.Shifting Boundaries: The Private, the Public, and the Welfare State. In: KATZ, Michael B.; SACH $\beta$ E, Christoph (Coord.). The Mixed Economy of Social Welfare. Baden-Baden: Nomos, p. 72-94, 1996.

FURTADO, Celso. Desenvolvimento e subdesenvolvimento. Rio de Janeiro: Contraponto, 2009.

Nacional: Publifolha, 2000.

Formação econômica do Brasil. São Paulo: Companhia Editora O Capitalismo global. São Paulo: Paz e Terra, 2001.

Quando o futuro chegar. In: SACHS, Ignacy; WILHEIM, Jorge; PINHEIRO, Paulo Sérgio. Brasil: um século de transformações. São Paulo: Companhia das Letras, 2001.

GALENSON, Walter; LEIBENSTEIN, Harvey. Criteri d'investimento, produttività e sviluppo economico. In: ALLIONE, Miro (Coord.). Le decisioni di investimento pubblico. Milão: Franco Angeli, 1971.

GARNER, Bryan A. (Ed.). Black's Law Dictionary. St. Paul, Minn.: Thomson West Group, 2004.

GRAU, Eros Roberto. A ordem econômica na Constituição de 1988. São Paulo: Malheiros, 2006.

GRAZIANI, Augusto. La teoria delle scelte negli investimenti pubblici. Nápoles: Jovene, 1961.

HEIDEGGER, Martin. A questão da técnica. Scientiæ Studia, São Paulo, v. 5, n. 3, p. 375-398, 2007.

HOUAISS, Antônio; VILlAR, Mauro de Salles. Dicionário Houaiss da língua portuguesa. Rio de Janeiro: Objetiva, 2001.

HUBERMAN, Leo. História da riqueza do homem. Trad. Waltensir Dutra. Rio de Janeiro: Zahar, 1974. 
IPEA - Instituto de Pesquisas Econômicas Aplicadas. Como anda o investimento público no Brasil?, Comunicado n. 126, 29 nov. 2011.

IRTI, Natalino. Verso un superamento del diritto? - Il destino del diritto e la volontà di potenza della tecnica. In: Fondazione Italiana per Il Notariato; Fondazione Corriere della Sera. Il diritto nell'età della tecnica. 17 mai. 2012.

Il mondo e lo sguardo giuridificante. In: IRTI, Natalino. Diritto senza verità. Roma-Bari: Laterza, 2011.

L'ordine giuridico del mercato. Roma-Bari: Laterza, 2001.

KEYNES, John Maynard. Teoria geral do emprego, do juro e da moeda. Trad. Manuel Resende. Lisboa: Relógio d'Água, 2010.

LOPES, José Reinaldo Lima. Iluminismo e Jusnaturalismo no Ideário dos Juristas da Primeira Metade do Século XIX. In: JANCSON, Istvan (Org.). Brasil: formação do Estado e da Nação. São Paulo: Hucitec, 2003.

MACARINI, José Pedro. A política econômica do governo Costa e Silva 1967-1969. Rev. econ. contemp. [online]. v. 10, n.3, p. 453-489, 2006. Disponível em: http://www.scielo.br/. Acesso em: 16 fev. 2013.

. A política econômica do governo Médici: 1970-1973. Nova econ. [online]. v.15, n.3, p. 53-92, 2005. Disponível em: <http://www.scielo.br/. Acesso em: 16 fev. 2013.

MANKIW, N. Gregory. Introdução à economia. Trad. Allan Vidigal Hastings. São Paulo: Thomson Learning, 2006.

MARTINS, Judith-Costa. Os campos normativos da boa-fé objetiva: as três perspectivas do direito privado brasileiro. In: AZEVEDO, Antonio Junqueira de; TORRES, Heleno; CARBONE, Paolo. Princípios do Novo Código Civil Brasileiro e outros temas. São Paulo: Quartier Latin, 2010.

MATTEI, Ugo. Beni Comuni - un manifesto, Roma-Bari: Laterza, 2011.

MEIRELLES, Hely Lopes. Direito Administrativo Brasileiro. São Paulo: Malheiros, 2003.

MELlo, Celso Antônio Bandeira de. Curso de Direito Administrativo. São Paulo: Malheiros, 2009.

MIRANDA, Pontes de. Tratado de Direito Privado - Parte Geral, tomo V, Rio de Janeiro: Borsoi, 1955. 
MONCADA, Luís Cabral de. Direito Econômico. Coimbra: Coimbra Editora, 2000.

NUNES, Antonio José Avelãs. Uma introdução à economia política. São Paulo: Quartier Latin, 2007.

NUSDEO, Fábio. Curso de Economia. São Paulo: Revista dos Tribunais, 2010, p. 297 298.

Desenvolvimento econômico - um retrospecto e algumas perspectivas.

In: SALOMÃO FILHO, Calixto (Coord.). Regulação e desenvolvimento. São Paulo: Malheiros, 2002.

OLIVEIRA, Régis Fernandes. Responsabilidade fiscal. São Paulo: Revista dos Tribunais, 2002.

OLIVERCRONA, Karl. Linguagem jurídica e realidade. São Paulo: Quartier Latin, 2005 .

OPPO, Giorgio. Diritto dell’impresa - scritti giuridici I, Pádua: CEDAM, 1992.

ORTINO, Sergio. La sfida della Banca d'Italia all'inizio del suo secondo centenario. In: Atti di Convegno sul tema: Despecializzazione e privatizzazione degli enti creditizi. Il ruolo della Banca d'Italia, Universidade de Salerno, Faculdade de Economia, Nápoles: Edizioni Scientifiche Italiane, p. 35-47, 13-14 out. 1995.

PEREIRA, Caio Mario da Silva. Instituições de Direito Civil. Rio de Janeiro: Forense, 2009.

PINHEIRO, Armando Castelar; GIAMBIAGI, Fabio. Os antecedentes macroeconômicos e a estrutura da privatização no Brasil. In: A privatização no Brasil - o caso dos serviços de utilidade pública, Rio de Janeiro: BNDES-OCDE, p. 15-43, fev. 2000.

PRADO Jr., Caio. Evolução Política do Brasil: colônia e império. São Paulo: Brasiliense, 2007.

Publifolha, 2000.

Formação do Brasil Contemporâneo. São Paulo: Brasiliense:

História e desenvolvimento - a contribuição da historiografia para a teoria e prática do desenvolvimento brasileiro. São Paulo: Brasiliense, 1999.

RADBRUCH, Gustav. Filosofia do direito. Trad. L. Cabral de Moncada. Coimbra: Armenio Amado, 1997.

Introdução à Ciência do Direito. São Paulo: Martins Fontes, 1999. 
RAJARAM, Anand; LE, Tuan Minh; BILETSKA, Nataliya; BRUMBY, Jim. A Diagnostic Framework for Assessing Public Investment Management. Policy Research Working Paper WPS 5397, Washington: Banco Mundial, ago.2010.

RÁO, Vicente. Ato Jurídico - noção, pressupostos, elementos essenciais e acidentais. O problema do conflito entre os elementos volitivos e a declaração, atual. Ovídio Rocha Barros Sandoval. São Paulo: Revista dos Tribunais, 1999.

REALE, Miguel. Filosofia do direito. Saraiva: São Paulo, 1965.

Introdução à filosofia. São Paulo: Saraiva, 1989

Lições preliminares de direito. São Paulo: Saraiva, 2000.

ROUBIER, Paul. Droits subjectifs et situations juridiques. Paris: Dalloz, 2005.

SALOMÃO FILHO, Calixto. Regulação e desenvolvimento. In: SALOMÃO FILHO, Calixto (Coord.). Regulação e desenvolvimento. São Paulo: Malheiros, 2002.

SCAFF, Fernando. A efetivação dos direitos sociais no Brasil - garantias constitucionais de financiamento e judicialização. In: SCAFF, Fernando; ROMBOLI, Roberto; MIGUEL, Revenga (Coord.). A eficácia dos direitos sociais. São Paulo: Quartier Latin, p. 22-42, 2010 .

SCHUMPETER, Joseph A. Teoria do desenvolvimento econômico: uma pesquisa sobre lucros, capital, crédito e ciclo econômico. Trad. Laura Schlaepfer. Rio de Janeiro: Fundo de Cultura, 1961.

SICHES, Luis Recaséns. Introducción al estudio del derecho. Cidade do México: Porrúa, 1970.

SILVA, Deonisio da. De onde vêm as palavras: origens e curiosidades da língua portuguesa. Osasco: Novo Século, 2009.

SILVA, José Afonso da. Curso de Direito Constitucional Positivo. São Paulo: Malheiros, 2008.

SIMPSON, J.A.; WEINER, E.S.C. The Oxford English dictionary. Oxford: Clarendon Press, 2004, v. 3.

SKOUTERIS, Thomas. The notion of progress in International Law Discourse. Haia: T.M.C. Asser Press, 2009.

STIGLITZ, Joseph E.; WALSH, Carol E. Introdução à macroeconomia. Trad. Maria José Cyhlar Monteiro. Rio de Janeiro: Campus, 2003. 
TAMANAHA, Brian Z. As lições dos estudos sobre direito e desenvolvimento. Revista DireitoGV, n. 9, trad. Tatiane Honório Lima, ver. José Rodrigo Rodrigues, São Paulo, p. 187-196, jan.-jun-2009.

TELLES Jr., Goffredo da Silva. A criação do direito. São Paulo: Juarez de Oliveira, 2004. O direito quântico. São Paulo: Max Limonad, 1980.

Introdução à Ciência do Direito. Faculdade de Direito da

Universidade de São Paulo. Departamento de Apostila do Centro Acadêmico XI de Agosto, São Paulo, 1953.

VENANCIO FILHO, Alberto. A intervenção do Estado no domínio econômico, Rio de Janeiro: FGV, 1968.

VERGOTTINI, Giuseppe. Ordem pública. In: BOBBIO, Norberto; MATTEUCCI, Nicola; PASQUINO, Gianfranco. Dicionário de política. Brasília: Ed. UnB, 2007.

VIANNA, Oliveira. O idealismo da Constituição. Rio de Janeiro-Recife-São Paulo: Nacional, 1939.

VIDIGAL, Geraldo de Camargo. Fundamentos do Direito Financeiro. São Paulo: Revista dos Tribunais, 1973.

dos Tribunais, 1977. Teoria geral do direito econômico. São Paulo: Revista

WEBER, Max. Economia e sociedade. Brasília: Ed. UnB, v.1 e v.2, 2000. 